\title{
39. SUMMARY AND SYNTHESIS OF LATE MIOCENE TO RECENT SEDIMENTARY AND PALEOCEANOGRAPHIC EVOLUTION OF THE TYRRHENIAN SEA, WESTERN MEDITERRANEAN: LEG 107 OF THE OCEAN DRILLING PROGRAM1
}

\author{
Alastair Robertson, ${ }^{2}$ Werner Hieke, ${ }^{3}$ Georges Mascle, ${ }^{4}$ Floyd McCoy, ${ }^{5}$ Judith McKenzie, ${ }^{6}$ \\ Jean-Pierre Rehault, ${ }^{7}$ and Renzo Sartori ${ }^{8}$
}

\begin{abstract}
The main objective of this paper is to review and synthesize all the paleoenvironmental information gained by the shipboard sedimentological party during Leg 107 of the Ocean Drilling Project in the Tyrrhenian Sea. The drilling on this leg was so successful that it is possible to construct an almost unique synthesis of an entire small ocean basin. ODP Leg 107 drilled a transect of ten holes at seven sites across the Tyrrhenian Sea from southeast to northwest, documenting the sedimentary and paleoceanographic evolution of a small ocean basin created by crustal extension in an area of broadly continental collision. Following early Miocene juxtaposition of the Sardinia-Corsica block with Adria to the east, crustal extension was initiated and rifting of the northeast Tyrrhenian Sea took place in late Miocene and early Pliocene to form the Sardinian passive margin. A classic transgressive succession comprises coarse subaerial clastic sediments (Site 654) derived from metamorphic basement and sedimentary cover rocks, similar to Sardinia, overlain by coastal to shallow marine (glauconitic), hemipelagic, and pelagic carbonates (Site 654). During early Messinian, organic-rich siliceous sediments, comparable with the Sicilian Tripoli, accumulated in a productive basin that was anoxic at depth (Site 654). Deposition during the Messinian salinity crisis comprised the following facies: finely-laminated gypsum precipitated in a desiccating basin affected by periodic marine incursions (Site 653); siliciclastic, organic-rich muds and nodular anhydrite apparently accumulated in a closed inward-draining fresh water, brackish and/or hypersaline lake, or desiccating basin (Site 652) subject to possible marine incursion; sulfur-rich sediments, possibly deposited near the shores of a saline lake (Holes 653A, -B); and, lastly, coarse subaerial clastics shed from an active fault-block composed of metamorphosed ophiolitic rocks of Ligurian or Piedmontese type (Holes 656A, -B). Along the eastern basin margin (Site 652) provenance was from low-grade metamorphic and Mesozoic-Tertiary cover rocks, as exposed in Peninsular Italy and Sicily. An end Messinian marine transgression reworked terrestrial sands (Holes 653A, -B), reddish silts (Holes 656A, -B, Hole 652), and multicolored clays (Site 654) into basal Pliocene hemipelagic clays and muds. During latest Messinian-Pliocene new oceanic-type crust was created in the Vavilov Basin to the southeast (Site 651), associated with mantle protrusion, basaltic lava eruption, sill intrusion, and breccia formation. Overlying pelagic carbonates were dolomitized by low-temperature hydrothermal fluids (ODP Sites 651, 650; DSDP Site 373). Several generations of carbonate sediment and hydrothermal cement fill cracks in pillow basalt on the Cortani Ridge, a tholeiitic basalt seamount (Site 655).

Late Pliocene and Pleistocene intervals in both the igneous-floored basins, Marsili and Vavilov, largely comprise turbiditic volcaniclastic sediments derived from the Southern Apennine potassic Roman province to the east (Site 651) and the calc-alkaline and shoshonitic Eolian islands to the southeast (Site 650). In situ tephra is rare. Volcanic glass is commonly altered to zeolite and smectite. Quaternary sea-level changes influenced deposition; sediment was trapped in nearshore basins during sea-level highstands and reworked to depocenters as sea level fell. Sapropels and sapropelic layers are now well documented from the Tyrrhenian Sea in Leg 107 late Pliocene and Pleistocene successions. Volcanic, tectonic, and climatic effects caused sediment instability in the Vavilov and Marsili Basins (Sites 650, 651), evidenced by turbidities, mass-flow, slumping, dewatering structures, and syn-sedimentary faulting. The igneous basement of the Tyrrhenian Sea formed above a subduction zone and has a high potential for ultimate preservation on land during continental collision, comparable with some emplaced Tethyan ophiolite complexes.
\end{abstract}

\section{INTRODUCTION}

Drilling the Tyrrhenian Sea in the Western Mediterranean (Fig. 1) during Leg 107 exemplifies the tectonic and sedimentary evolution of a small oceanic basin created by crustal extension

\footnotetext{
${ }^{1}$ Kastens, K. A., Mascle, J., et al., 1990. Proc. ODP, Sci. Results, 107: College Station, TX (Ocean Drilling Program).

2 Department of Geology and Geophysics, University of Edinburgh, West Mains Road, Edinburgh EH9 3JW, United Kingdom.

${ }^{3}$ Lehrstuhl für Algemeine, Angewandte und Ingenieur-Geologie, Technische Universität München, Federal Republic of Germany.

${ }^{4}$ Institut Dolomieu, Université Scientifique et Médicale de Grenoble, Grenoble, France.

5 Lamont-Doherty Geological Observatory of Columbia University, Palisades, NY 10964.

6 Department of Geology, University of Florida, Gainesville, FL 32611.

7 Laboratoire de Géodynamique Sous-Marine, Université Pierre et Marie Curie, 06230 Villefranche-sur-Mer, France.

${ }^{8}$ Istituto di Geologia Marina, 40127 Bologna, Italy.
}

in a setting of broadly continental collision. The purpose of this paper is to summarize and discuss the sedimentological and paleoceanographic data and interpretations from Leg 107, based mainly on shipboard data. The paper can be considered as a background to specialized sedimentological studies in this volume. Comparative aspects of the on-land geology (Sartori et al., 1987a, b) and the geophysics of the Tyrrhenian Sea (Rehault et al., 1987) are summarized in Kastens, Mascle, et al. (1987). Tectonic and magmatic aspects of the evolution of the Tyrrhenian Sea, based on Leg 107, are treated elsewhere in this volume (see also Stanley and Wezel, 1985).

During Leg 107, a transect of ten holes was drilled at seven sites across the Tyrrhenian Sea (Figs. 2, 5, 7, 9, 10, 12, 13, 15). The results support earlier hypotheses of the Tyrrhenian Sea as a back-arc basin formed above a northwestward-dipping subduction zone (Boccaletti and Guazzone, 1972; Malinverno and Ryan, 1986). As summarized by Rehault et al. (1987), a subduction zone dips northwestward under Calabria and the northeast- 


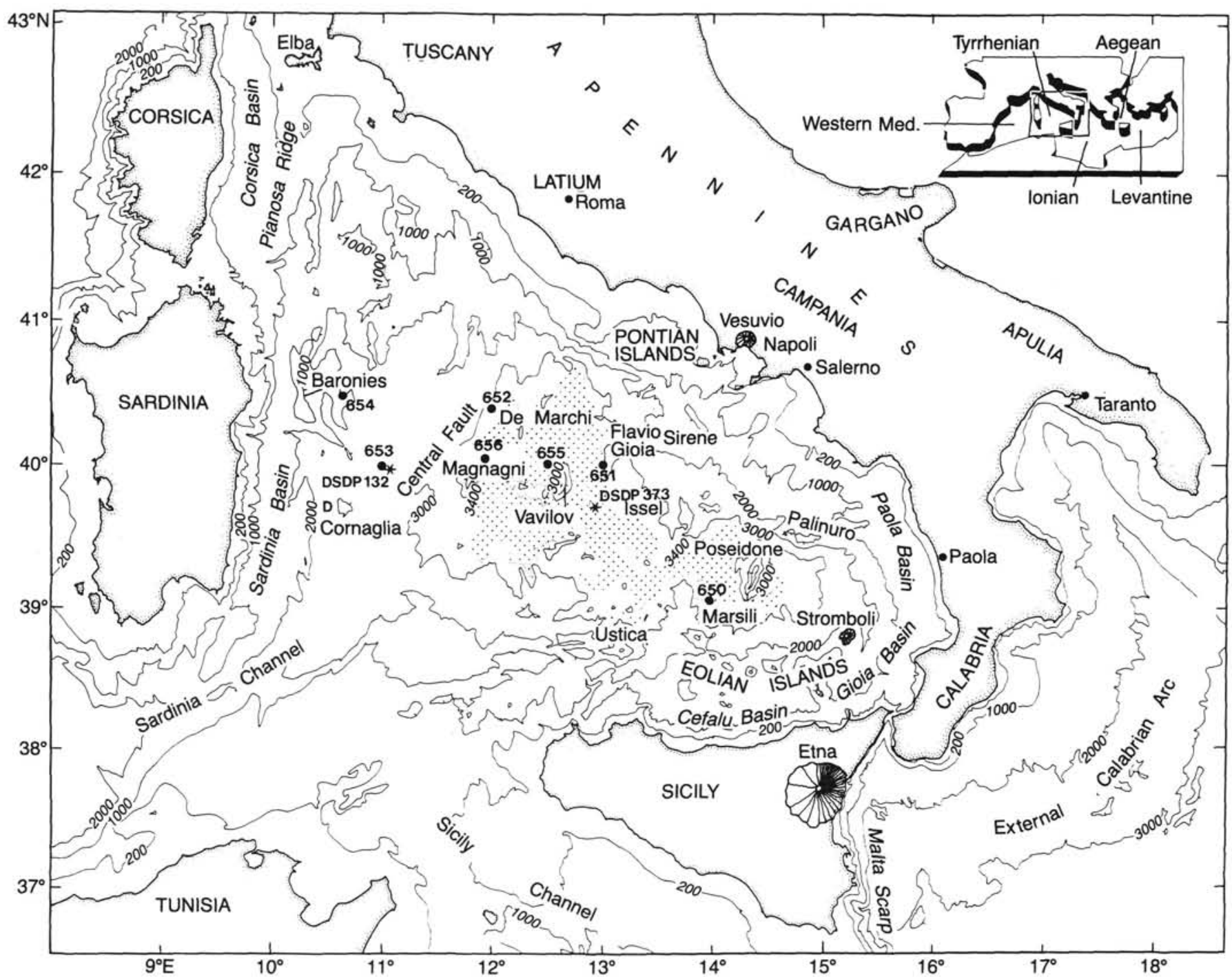

Figure 1. Map of the Tyrrhenian Sea and surrounding areas; after Kastens, Mascle, et al. (1987).

ern peninsula of Sicily (Fig. 1). The Eolian island volcanic arc relates to this subduction (Barberi et al., 1974). The subducting crust, presumably oceanic, is assumed to be located in the Ionian Sea to the southeast and may be a remnant of the Mesozoic Tethys ocean (Laubscher and Bernoulli, 1977; Biju-Duval et al., 1977). Within the Tyrrhenian Sea, geophysical data (Malinverno and Ryan, 1986) suggest that the Marsili and Vavilov Basins, northwest of the Eolian arc (Fig. 1), can be considered as young oceanic crust evolved during back-arc basin formation; the eastern margin of Sardinia to the northwest is a passive margin, similar in crustal structure to the Mesozoic passive margins of the Atlantic (Boillot et al., 1980); the western margin along peninsular Italy is presumed to be a passive margin dominated by left-lateral shear abutting the Apenninic compressional structure.

Sedimentary successions drilled during Leg 107 shed light on a wide range of tectonic, sedimentary, and paleoceanographic processes in this diverse tectonic setting: the sedimentary history of subsidence and transgression associated with continental rifting; latest Miocene-earliest Pliocene rift-drift breakup; sedimentation on oceanic crust, in the Marsili and Vavilov Basins; paleoenvironments of the Mediterranean Messinian salinity crisis; and Plio-Quaternary volcaniclastic sediments of the Marsili and Vavilov Basins. Plio-Quaternary organic-rich sediments are also briefly summarized (McKenzie et al., this volume), as are implications for Tethyan tectonic evolution. Our discussion that follows addresses these concerns, organized to present inference based upon data from oldest to youngest sediments and sedimentary succession recovered by drilling.

\section{Undated? Tortonian Succession: Site 654}

\section{Location and Lithology}

The oldest sediments drilled in the Tyrrhenian Sea are located on the upper part of the Sardinian margin, interpreted as a passive continental margin to a small "back-arc" ocean basin (Rehault et al., 1987; Kastens, Mascle, et al., 1987; Kastens et al., this volume). At Site 654 , the basal sediments, drilled into a wedging seismic unit, interpreted as syn-rift sediments, comprises $58 \mathrm{~m}$ of coarse-grained, pebbly, clastic sediments with a reddish muddy matrix (Fig. 10). These sediments can be dated only as before the uppermost Tortonian age of the overlying margin facies (Kastens, Mascle, et al, 1987). Individual pebbles and cobbles, both metamorphosed and unmetamorphosed, are either rounded or subangular and range in size up to $9 \mathrm{~cm}$. Many pebbles exhibit strongly oxidized edges (Plate 1, 1). 


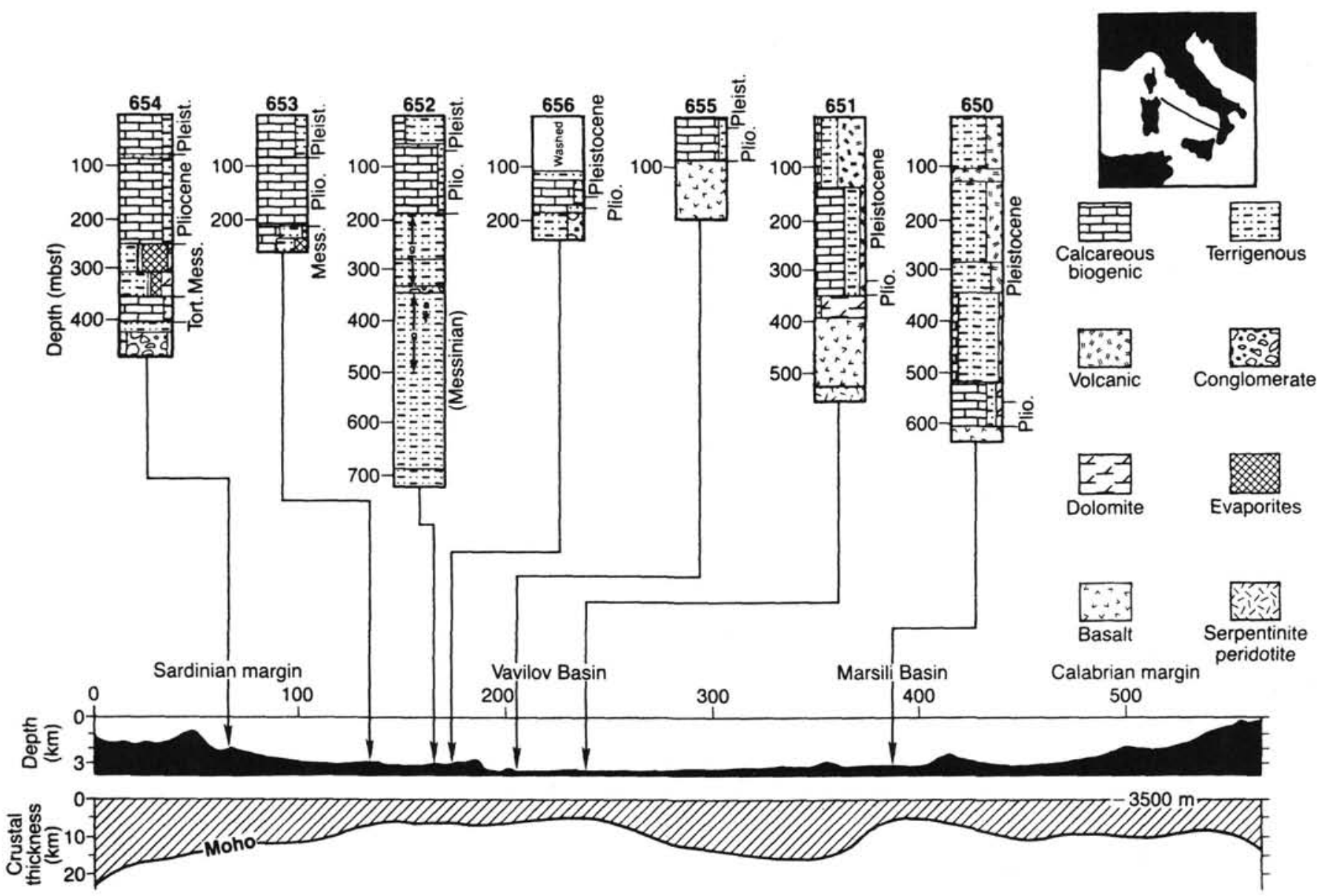

Figure 2. Bathymetric and crustal section across the Tyrrhenian Sea (see location in inset). Simplified stratigraphic columns of Leg 107 drill sites are projected along the transect (after Kastens, Mascle, et al., 1987).

Unmetamorphosed pebble lithologies are limestone, dolostone, and siltstone. Parallel lamination and microcross-lamination are common, small-scale burrows less common; crinoidal biosparite with calcispheres and agglutinating foraminifera are also present locally. Metamorphic rock lithologies include marble, quartzitic rock, and dolostone with small greenschist inclusions. These pebbles are commonly schistose and veined, with tension gashes and small-scale brittle shear features; veins are quartz or coarse sparry calcite, the latter in some cases cutting schistosity, but themselves folded.

The pebble horizon is overlain by undated reddish sandy calcareous mudstone mixed with gravel, of which only $1.3 \mathrm{~m}$ were recovered. Clasts are up to $10 \mathrm{~cm}$ in size, angular to subrounded, and occasionally well-rounded.

\section{Depositional Environment: Alluvial-fan Deposition}

These basal sediments are interpreted as the product of local subaerial erosion and fluvial deposition on a small alluvial fan, or fan-delta (Fig. 3). Seismic records suggest an erosional unconformity present on a tilted fault block that dips upsection to the east (Kastens and Mascle, this volume). Rapid erosion of a tectonically active fault block in a subaerial environment is inferred from lithologic criteria in cores and from the tectonic setting inferred from seismic profiles. Comparisons with the onland geology of Sardinia (Sartori et al., 1968) suggest the metamorphic rocks were derived from basinal carbonate successions of mid-Paleozoic, possibly Devonian, age. Less altered clasts come from a carbonate platform, possibly of later Paleozoic age. Dredging and submersible studies, summarized by Sartori et al. (1987), indicate that similar Sardinian-type Hercynian basement and Mesozoic cover rocks crop out east of Sardinia, west of the Central Fault, along the Sardinian continental margins.

\section{UPPER TORTONIAN TRANSGRESSIVE SEDIMENTS: SITE 654}

\section{Lithology}

The succession at Site 654 passes upward into $55.0 \mathrm{~m}$ of oligomict sandstone containing glauconite and marly calcareous chalk (Fig. 10). In general, the most coarse-grained siliciclastic sediments occur near the base of this interval, while the abundance of bioclastic and fine-grained siliciclastic matrix increases upsection. Gravel exhibits a matrix-supported texture, with angular to sub-angular small pebble-sized fragments. Sandstone is matrix-rich, poorly-sorted, and comprises quartz, mica, gypsum, glauconite, pyrite, and carbonate. Bioclasts include large oyster shells, bored by Cliona-type sponges, numerous benthic forams (Plate 3,7 ) and echinoderm plates (Plates 1,$1 ; 3,1$ ). Large shell fragments exhibit an imbrication texture.

\section{Depositional Environment: Deepening Marine Conditions}

The sea transgressed coastal areas and mixed siliciclastic and calcareous sediments that had accumulated in shallow nearshore areas (Fig. 3). Foraminifera assemblages suggest a low sa- 


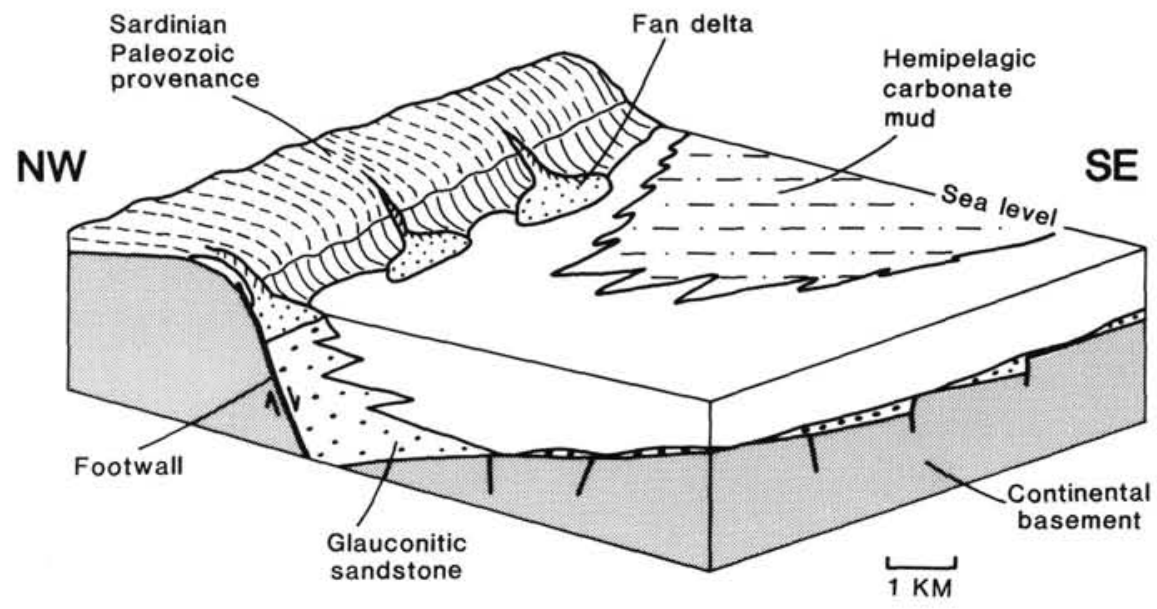

Figure 3. Block diagram to illustrate Tortonian transgressive paleoenvironments at Site 654. See text for explanation.

linity environment initially, followed by fully marine conditions with shallow-water foraminifera (Shipboard Scientific Party, 1987d). Shell imbrication indicates active currents, possibly in a beach or coastal setting. Later, more matrix-rich sediments accumulated in quiet, possibly deeper seas in a setting where adjacent tilted fault-blocks possibly still formed islands separated by bays, isolated from high-energy currents. By analogy to the modern oceans, glauconite suggests formation along the Sardinian continental shelf at depths from tens to hundreds of meters, in a slow-deposition, transgressive succession (Bell and Goodell, 1967; McRae, 1972), although deeper water deposition may also be possible (Odin and Matter, 1981), glauconite typically developed in foraminifera shells and as pellets in local anoxic micro-environments within otherwise oxidizing depositional settings. Small volumes of pyrite also formed in the Site 654 sediments, also suggestive of these conditions.

Summarizing, the basal, ?Tortonian interval of Site 654 on the upper Sardinian margin is a classic example of a marine transgression over rifted, subsiding continental crust (Fig. 3). Similar rift successions are well exposed on land in the AlpineMediterranean Tethys area, where ancient passive continental margin successions were tectonically emplaced, for example, the Antalya Complex, southwest Turkey (Dumont et al., 1972; Robertson and Woodcock, 1982, 1984), the Pindos nappes of central Greece (Aubouin et al., 1970; Price, 1976), the Hamrat Duru Group in the Oman Mountains (Glennie et al., 1973; Searle and Graham, 1982), and the Italian Dolomites (Bosellini and Rossi, 1974). Rifting in these areas took place in a low latitude setting where carbonate platforms were constructed on fault blocks and seamounts. Rifting of the Tyrrhenian Sea occurred in a back-arc setting, whereas the Mesozoic Tethyan rifts formed by continental rifting more similar to the modern Red Sea: the depositional environment remain similar, however.

\section{UPPER TORTONIAN-EARLY MESSINIAN NANNOFOSSIL OOZES: SITE 654}

\section{Lithology}

The succession at Site 654 passes into $55 \mathrm{~m}$ of strongly burrowed, homogeneous nannofossil ooze of uppermost Tortonian and lowermost Messinian age (Fig. 4). The transition from the underlying siliciclastic and bioclastic sediment is marked by a gradual decrease in sand, silt, and bioclasts, with increasingly abundant foraminifers and a few large mollusc fragments. Planktonic foraminifers became more abundant higher in the succes- sion, often in centimeter-thick layers. Nannofossil oozes are rich in asphalt-like hydrocarbons, often concentrated in small burrows, sometimes of Chondrites-type. Individual burrows are usually dark grey or black and contain finely disseminated pyrite, as framboids. The sediment is locally replaced by pyrite.

\section{Depositional Environment: Fertile Deep-sea Deposition}

Organic-rich fine-grained carbonate accumulated in quiet, unrestricted seas (Fig. 3) up to $1000 \mathrm{~m}$ deep, from faunal evidence, summarized elsewhere (Kastens, Mascle, et al., 1988). The adjacent fault block subsided to form a deeper basin to landward, cutting off terrestrial siliciclastic input from Sardinia: thus commenced an inversion of relief still perpetuated in the modern bathymetry. Organic matter, nannofossils, and occasional fish teeth suggest fertile seas that were circulating and mixing to allow oxygenated bottom-waters. Upwelling may have taken place in what was probably a relatively narrow seaway, comparable with the modern Gulf of California (Curray, Moore, et al., 1982). The organic-rich bottom sediments supported abundant bottom life, and any original sedimentary structures were almost totally destroyed by burrowing. During diagenesis, pyrite framboids precipitated in zones where abundant organic matter was reduced, such as in burrows and in planktonic accumulation of foraminifera shells. Minor volumes of dense hydrocarbons were generated, during in situ diagenesis (Kastens, Mascle, et al., 1987). In summary, the burrowed nannofossil oozes accumulated in moderately deep, unrestricted, fertile seas with good circulation, after subsidence and transgression of neighboring land areas that took place in response to active tectonic rearrangement of the submarine physiography.

\section{LOWER MESSINIAN ANOXIC SEDIMENTS: SITE 654}

\section{Lithology}

Upward, at Site 654 , there is an abrupt appearance of dark finely-laminated fine-grained sediments, dated lower to middle Messinian, that contrast with the underlying burrowed nannofossil oozes (Fig. 10). The Messinian succession comprises 36.3 $\mathrm{m}$ of relatively homogeneous claystone and siltstone, variably, dolomitic and calcareous, with minor volcanic ash. Sedimentary structures comprise the following: very fine, millimeterscale, parallel lamination that resembles varves (Plate 1, 2); graded, centimeter-scale partings of siltstone and claystone; small-scale flaser lamination, micro-cross-lamination, and small 


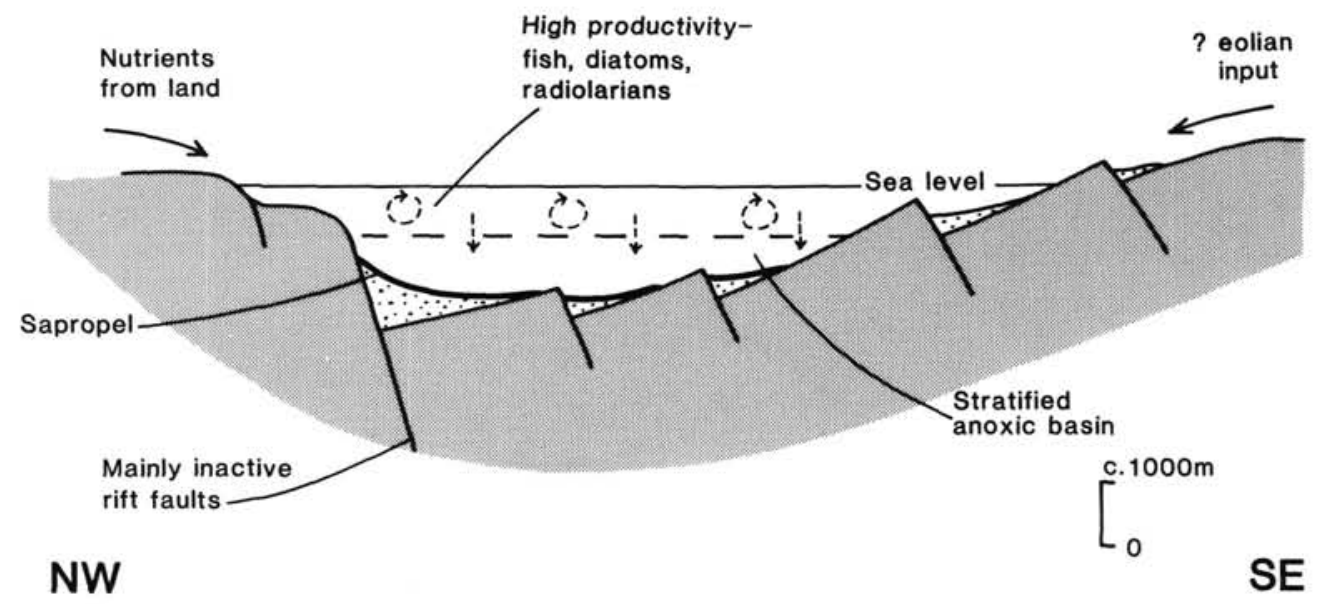

Figure 4. Schematic cross-section across lower Messinian basin at Site 654. See text for explanation.

scour structures. The biota are dominantly diatoms, radiolarians, and sponge spicules, with occasional fish teeth and fish scales. There is a distinct color-banding, with various hues of gray, corresponding to variable organic carbon $(1 \%-2.4 \%)$ and carbonate $(8.96 \%-32.25 \%)$ content. Sediment instability is evidenced by thin debris-flows, convolute lamination and smallscale slump structures (Plate 1,3). Higher in this succession, thin interbeds rich in volcanic ash are now largely altered to dolomite and zeolites. Small concretions and disseminations of pyrite are also present.

\section{Depositional Environment: a Fertile Silled Basin}

Lower Messinian time at Site 654 on the upper Sardinian margin saw fertile seas with good organic carbon preservation (Fig. 4). The relative abundances of diatoms and radiolarians suggest that seas were comparatively fertile. As indicated by the well preserved fine lamination and the absence of burrowing, however, these Messinian sediments were anoxic, in contrast to the underlying Tortonian-early Messinian, burrowed nannofossil oozes. The most plausible explanation seems bottom-water stagnation (i.e., a stratified anoxic basin), while surface productivity remained quite high, during the earliest stage of the Messinian salinity crisis, when the Mediterranean Sea became isolated from the world ocean. Alternatively, the oxygen-minimum zone may have been greatly expanded, but without reaching basin depocenters at this stage. As the connection with the Atlantic through the Betic and Rif straits was increasingly constricted (Hsü et al., 1978), rates of evaporation exceeded open ocean recharge and sea level fell in the Mediterranean. Tilted rift fault blocks presumably still existed as seamounts, based on seismic profile evidence, but as sea level fell, several semi-isolated subbasins formed, separated by sills with little deep-water interchange. Continued nutrient inflow from surrounding land areas allowed surface productivity to remain high, consequently organic-rich sediments accumulated in a series of anoxic basins; comparable siliceous sediments are preserved on land as the Tripoli Formation (McKenzie et al., 1979).

\section{MESSINIAN EVAPORITIC PALEOENVIRONMENTS}

Messinian evaporitic sediments were drilled at four sites during Leg 107. The sediments recovered confirm the hypothesis of late Miocene desiccation of the Mediterranean Sea (Hsü et al., 1973, 1978). Previous interpretations of Messinian paleoenvironments were supported by comparisons with successions ex- posed on land, especially in Sicily (e.g., Decima and Wezel, 1973). During Leg 107 a Messinian evaporitic succession was completely penetrated and revealed an underlying sequence of open-marine Tortonian-aged pelagic sediments. With the aid of seismic data (Selli and Fabbri, 1971; Malinverno, 1981; Malinverno et al., 1981; Rehault et al., 1987; Kastens and Mascle, this volume), paleoenvironments of a single evaporitic basin can now be documented in more detail.

\section{Marginal Terrestrial Clastic Successions: Holes 656A and -B}

\section{Stratigraphy and Lithology}

Holes 656A and 656B are located on the western flank of the easternmost tilted fault block on the lower Sardinian margin, the De Marchi seamount (Figs. 1, 5). Basal sediments are unfossiliferous, but, based on lithological comparisons, are believed to be Messinian in age. The recovery at Holes 656A and 656B, comprises, respectively $57.3 \mathrm{~m}$ and $16.2 \mathrm{~m}$ of brilliantly colored reddish, variably lithified, clastic, calcareous and dolomitic sediments. At Hole 656B sediments are mainly calcareous and dolomitic mud, sand, and gravel. Sands are typically well-cemented by limonite and carbonate. Calcareous mudstone contains numerous scattered sand-, gravel-, and pebble-sized clasts of iron oxy-hydroxide and limonite-cemented sandstone, gypsiferous sandstone, marlstone, limestone, and dolomite. Intercalations of nannofossil ooze are interpreted as post-depositional slumps (Shipboard Scientific Party, 1987f).

The succession recovered from Hole $656 \mathrm{~A}$ is dominated by mostly angular to sub-angular clasts embedded in a matrix of drilling mud, with a $\sim 10$-m-thick intercalation of pebbly claystone and mudstone containing matrix-supported rudite. The clasts can be subdivided into mafic metamorphic, and unmetamorphosed sedimentary and igneous types. Mafic metamorphic clasts are banded and massive amphibolite, tremolite-rich metagabbro, metadolerite, and contain some blue amphibole. Alteration of ferromagnesian minerals to tremolite, actinolite, and talc is common. Metasedimentary rocks are quartzite, chloritic marble, and jasper, while the unmetamorphosed rocks include limonitic clay, mudstone, siltstone, fine-grained sandstone, red and white chert, silicified micritic limestone, calcarenite, shale, and altered greenstone. Clasts of crystalline sulfide include pyrite, chalcopyrite, and galena. The conglomerates are overlain by $10 \mathrm{~m}$ of dolomitic muds (Unit III, Core 8 ), mainly calcareous, and sandy or silty with rare reworked biogenic compo- 


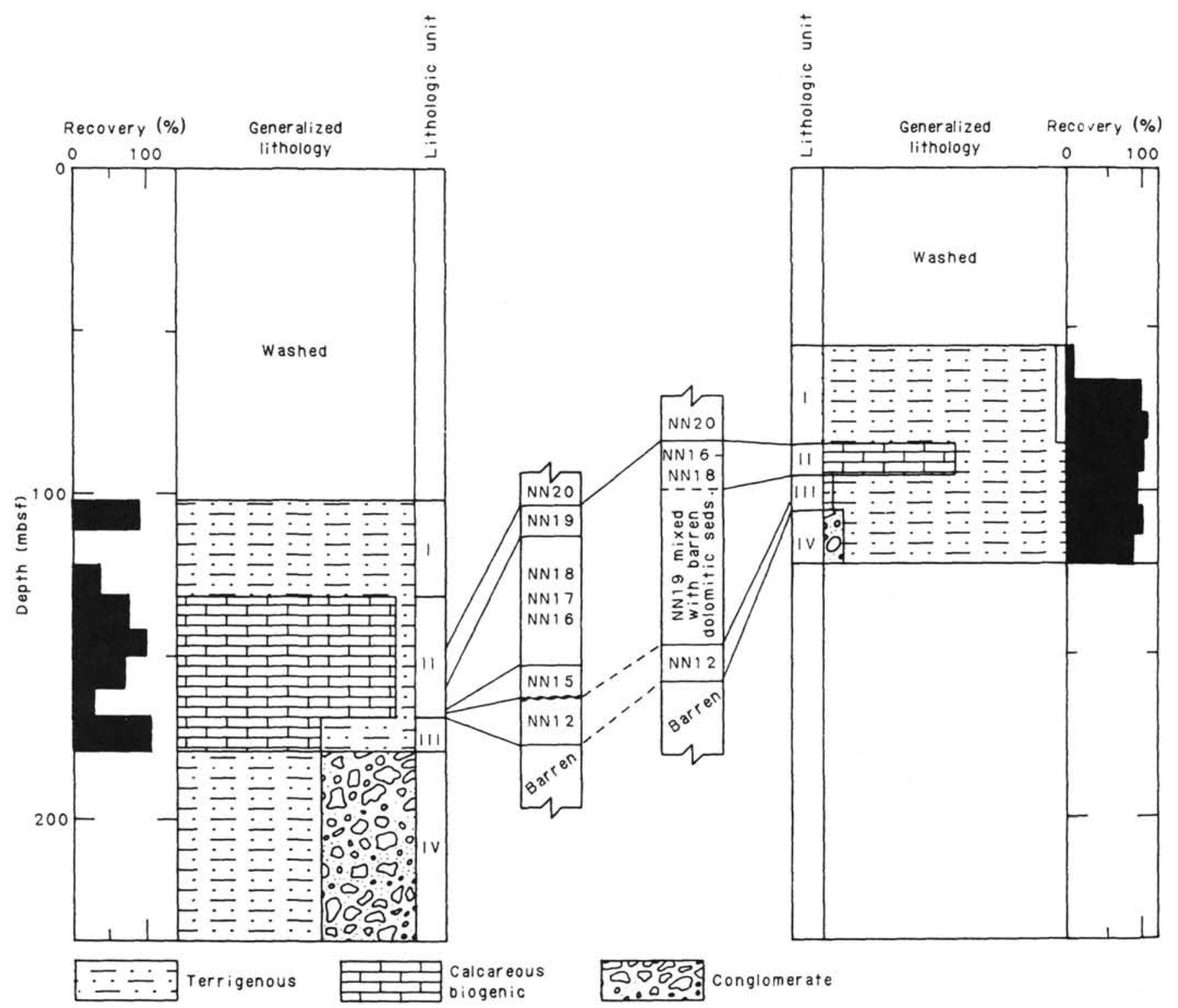

Figure 5. Summary of the sedimentary succession drilled at Holes 656A (left) and 656B (right) with detail of the main Pliocene-Pleistocene unconformities. Unit I, volcanogenic and detrital sediments; Unit II, nannofossil oozes; Unit III, dolomitic mud; Unit IV, conglomerate and red carbonate mud. After Kastens, Mascle, et al. (1987).

nents. A similar lithology was encountered in Hole 656B, interbedded as a slump between lower Pliocene and lower Pleistocene sediments.

\section{Depositional Environment: Alluvial Fans Shed From Local Fault Blocks}

The mafic igneous clasts were eroded from a metamorphosed ophiolite complex, associated sediments, and possible basement. Comparisons with land successions suggest derivation from metamorphosed Mesozoic ophiolitic rocks, of Piedmontese and Ligurian type (Ohnenstetter, 1979). Similar ophiolitic rocks occur beneath the Tyrrhenian Sea as far south as an imaginary line connecting the Alpine units of Corsica with Northern Calabria (north of the Cantanzaro isthmus) (Colantoni et al., 1981; Sartori et al., 1987a). In addition, phyllite, limestones, and granite of Paleozoic to Neogene age were confirmed by submersible studies of outcrops on De Marchi seamount (Gennesseaux et al., 1986). Seismic data confirm the De
Marchi seamount is the last tilted fault block on the lower Sardinian margin before oceanic-type crust is encountered. The clastic sediments, of inferred Messinian age, are texturally immature, and show evidence of intense weathering and subaerial oxidation, and are interpreted as immature alluvial fans shed from tilted fault blocks (Fig. 6). The coarseness, poor sorting, and angularity suggest local derivation, contrasting with more rounded clasts in ?Tortonian rudites on the upper Sardinian margin (Site 654; discussed below). These were eroded from a structurally and lithologically varied basement complex presumably exposed on the flanks of the De Marchi seamount. Similar breccias are known from a range of modern and ancient continental rift settings (e.g., Mitchell and Reading, 1986; Leeder and Gawthorpe, 1987).

In summary, stratigraphic successions at Site 656 comprise marginal clastic facies related to inferred Messinian rifting that took place along the present lower slope of the Sardinian margin. The overlying dolomitic muds, also of assumed Messinian 
age, would have accumulated on a saline and/or brackish lake following flooding and/or subsidence on adjacent rift fault block, and may be comparable with the Lago Mare dolomitic muds of the Eastern Mediterranean (Hsü et al., 1978) (Fig. 6).

\section{Clastic and Evaporitic Sediments: Site 652}

\section{Stratigraphy and Lithology}

Contrasting Messinian facies were cored northwest of the De Marchi Seamount (Site 656) on the lower slope of the Sardinian margin at Site 652 (Figs. 1, 7). The succession there comprises $538.2 \mathrm{~m}$ of nearly unfossiliferous fine-grained clastic and evaporitic sediments, with one conglomeratic horizon. In this thick sequence, the only fossils recovered were three specimens of Ammonia beccarii tepida, sparse ostracod fragments, and calcareous algae, together with abundant reworked Cretaceous and Paleogene nannofossils. Magnetostratigraphic data suggest that this entire pre-Pliocene succession would corresponds to $\mathrm{a} \sim 0.6$ Ma time of reversed polarity at the base of the Gilbert interval (between 4.79 and 5.41 Ma) (Channell and Torii, this volume), although, on purely stratigraphical grounds, it might appear that a slightly older, Messinian or pre-Messinian age is possible for the more lithified sediments at the base of the succession drilled.

At the base of this drilled section is $37.5 \mathrm{~m}$ of well lithified siltstone, sandy siltstone, and sandstone, often calcareous and/ or zeolitic. The succession passes upward into $338.7 \mathrm{~m}$ of less indurated, rather homogeneous, less calcareous, gray claystone, mudstone, sandy siltstone, and sandstone. These clastic sediments only exhibit repeated, centimeter-thick, well graded layers, often micro-cross-laminated. Occasional millimeter-thick partings are composed of red and yellow iron oxide-rich mud; analyses are given elsewhere (Robertson, this volume). Minor volumes of fine- to medium-grained plant debris also occur. Finely-laminated black shale occurs between 594.90 and 614.20 mbsf, with up to $11.3 \%$ organic carbon (Shipboard Scientific Party, 1987b). Centimeter-thick partings contain remnants of Botryococcus-type brackish water algae and rare brackish water foraminifera (Shipboard Scientific Party, 1987b). There are several intervals composed of nodular anhydrite, up to $5 \mathrm{~cm}$ thick, that exhibit classic "chicken-wire" texture. These nodules range from discrete to coalescing, with enterolithic structure and include occasional layers of massive anhydrite. In some cases, calcium sulfate (?originally gypsum), with a fine-grained satin-spar texture, has been replaced by secondary anhydrite nodules. The evaporites are distributed in seven main cycles, each with increasing amounts of calcium sulfate toward the top (Broglia et al., this volume).
Within this rather monotonous succession, 14 pebbles were recovered, ranging from 1 to $8 \mathrm{~cm}$ in size (Fig. 7). Downhole logging suggests an important conglomeratic interval is present from 334 to 344 mbsf. Pebbles recovered in cores are rounded and smooth; some appear to be flattened. Sediment instability is evidenced by syn-sedimentary micro-faults and micro-breccias, water-escape structures, and reverse, as well as normallygraded partings (Plate 2, 4). The Messinian succession terminates with a further $97.7 \mathrm{~m}$ of similar thin-bedded and finelylaminated, mostly fine- to medium-grained clastic sediments, without in situ evaporite minerals.

The provenance of the Messinian sediments was clearly varied. Siliciclastic components are polycrystalline quartz, strained quartz, plagioclase feldspar, muscovite, biotite, chlorite, and opaque minerals (Plate 3,6 ). Sedimentary rock fragments are common, mainly micrite with planktonic foraminifera, and coarser-grained neritic limestone with a neritic fauna that includes benthic forams and echinoderm plates. R. Sprovieri (pers. comm., 1985) identified Textularia sp., Globigerina sp., and Bolivina sp., that possibly were reworked from Miocene successions. Many of the coarser-grained clastic intercalations contain abundant silt- and sand-sized detrital gypsum and minor dolomite. Minor amounts of greenish volcanic glass are also present.

The pebbles are low-grade metamorphic rocks, and both siliciclastic and calcareous sedimentary rocks. Calcareous phyllite originated as a muddy sediment with biogenic remains, including benthic forams. Quartzarenite pebbles contain well-rounded quartz grains. Pebbles of polymict sandstone include metamorphic and igneous-derived quartz, calcite, dolomite, low-grade metamorphic rocks, including carbonaceous phyllite, ferromagnesian crystals, feldspathic igneous rocks, and possible glauconite. Bioclasts comprise mollusk fragments, echinoderm plates, and very rare bryozoa. Limestone pebbles consist of biomicrite, grainstone, and packstone. The biomicrite contains abundant calcitized radiolarians, planktonic forams (Heterohelix sp.), and rare possible Saccocoma-like remains. Various bioclasts and grainstones include large benthic forams (e.g., Amphisteginidae), bryozoa, red algae, echinoid plates, molluscan fragments, and rare planktonic forams. The packstone clasts consist of rudist fragments, green algae, benthic forams of arenaceous and Miliolinid-type, and mollusc fragments in a matrix including quartzose silt, with rare ostracods and planktonic forams.

\section{Evaporitic Paleoenvironments}

A notable feature of the Messinian section at Site 652 is the presence of anhydrite as massive layers and nodules occurring in rhythmic succession. These evaporites occur only in a narrow interval between $\sim 340$ and 420 mbsf in Cores 37-44 and are not

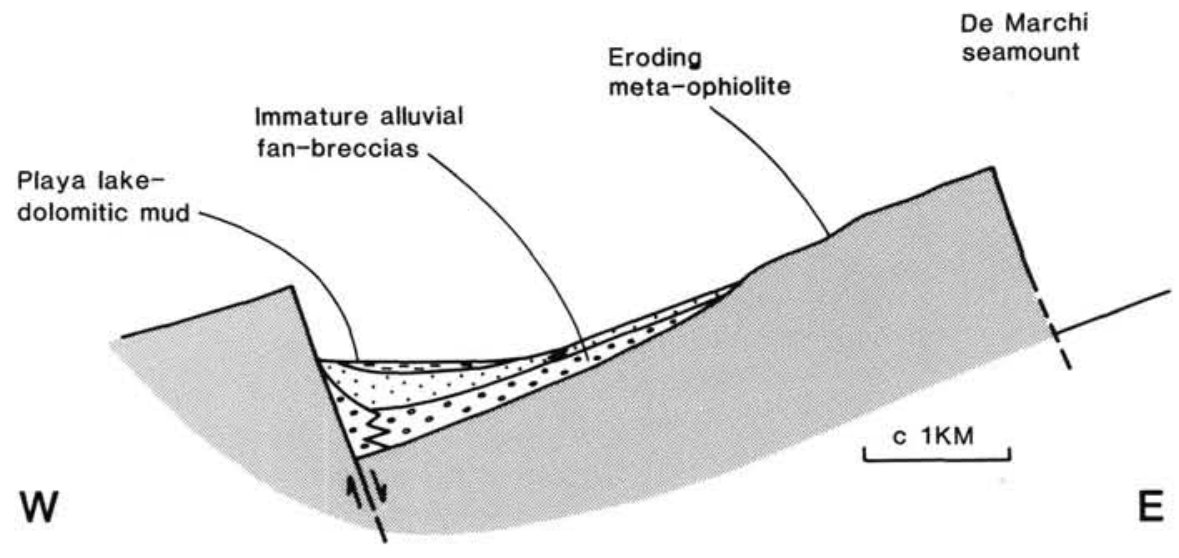

Figure 6. Schematic cross-section illustrating ?Messinian paleoenvironments at Holes 656A and -B. See text for explanation. 


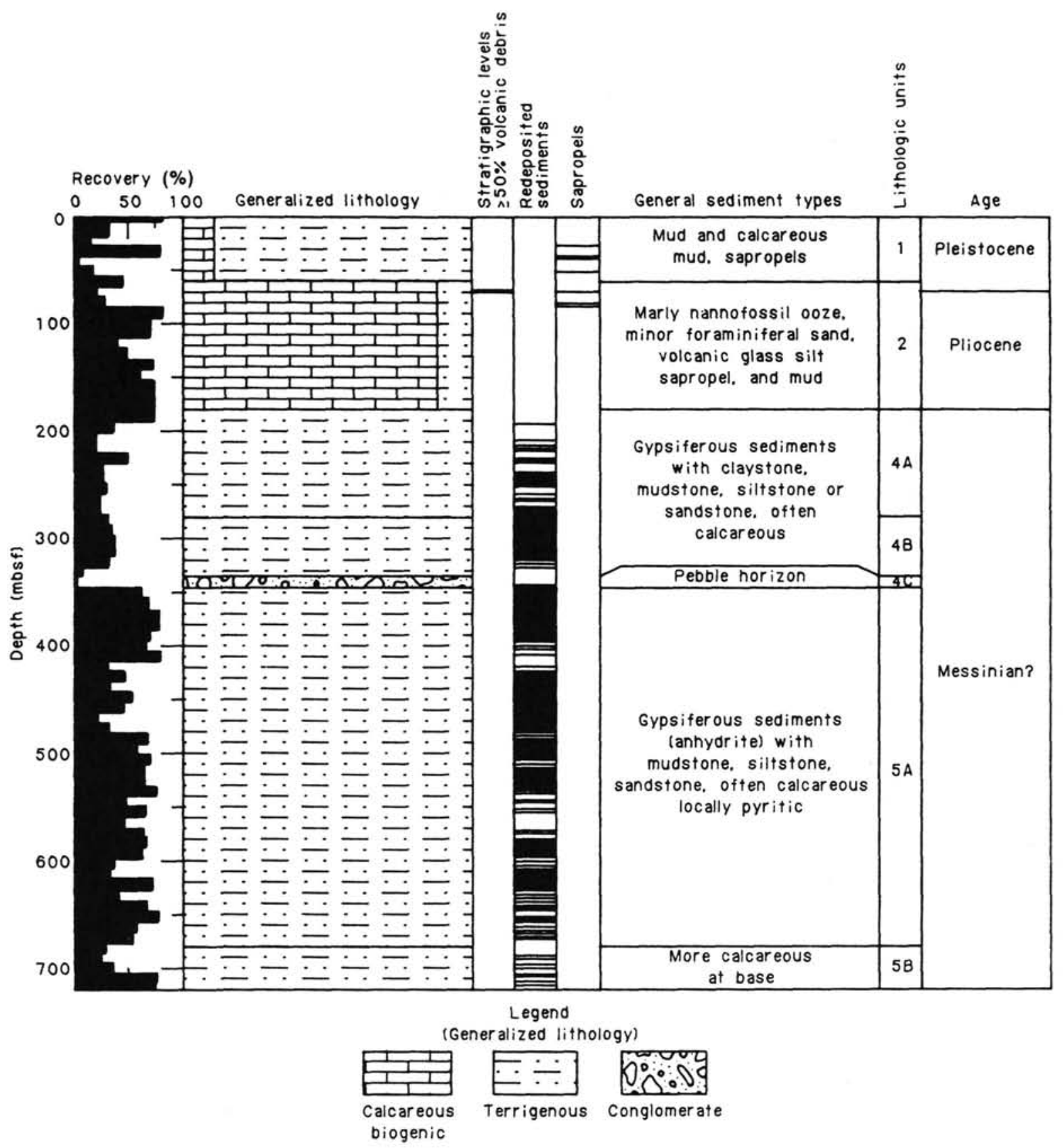

Figure 7. Generalized lithological column and drilling recovery at Site 652; after Kastens, Mascle, et al. (1987).

significantly present above or below these cores (Plate 3, 2). Anhydrite, rather than gypsum, is the stable phase (Hardie, 1967) at the physical condition encountered at this depth: in situ temperature estimated from the geothermal gradient measured in the hole at $\sim 400 \mathrm{mbsf}$, where the evaporites exist, is $70^{\circ} \pm 5^{\circ} \mathrm{C}$ (Shipboard Scientific Party, 1987b). Interstitial water salinities at these depths are nearly double that of seawater. X-ray diffraction confirms that the nodular calcium sulfate is anhydrite, although much detrital gypsum also occurs. This coexistence of gypsum and anhydrite was also noted by Garrison et al. (1978) in Messinian successions cored during Leg 42.

Three hypotheses for the deposition of the Site 652 Messinian sediments can be considered: (1) in a closed, inward-draining lake of variable salinity; (2) on a coastal plain, or sabkha; (3) deposition in a semi-enclosed marine lagoon.
1. Lacustrine origin. Criteria supportive of deposition mainly, or entirely, in a lake included the common occurrence of graded siliciclastic partings interpreted by shipboard sedimentologists as suspension deposits of possible storm origin; and infrequent interbeds of black shales (Plate 3,3 ) that included a brackish water biota, with an apparent absence of definite marine fossils. A modern comparable environmental setting might be saline lakes such as the Great Salt Lake of Utah (Hardie et al., 1978). The main problem, however, with this model is the occurrence of chicken-wire anhydrite, that today commonly forms in sabkhas (Shearman, 1966, 1982; Schreiber, 1982; McKenzie et al., 1980). Messinian-age sequences in Eastern Mediterranean and adjacent Paratethyan areas ("Lago Mare") (Steininger and Rogl, 1984) suggest cyclical alternations of finely-laminated dolomitic and gypsiferous muds and silts, similar to that cored by DSDP 
at Site 374 in the Ionian Sea (Garrison et al., 1978). Site 642 Messinian sediments are dissimilar, however, by containing abundant siliciclastic silt and sand, rather than carbonate and/or biogenic silica (diatomite) and this may not be typical of mid-latitudinal lake deposits.

2. Sabkha origin. An origin in a hypersaline coastal plain, sabkha, or marginal setting, sabkha-related to a hypersaline (playa) lake is capable of readily explaining the occurrences of chicken-wire anhydrite. The nodular anhydrite, however, is rare and algal lamination virtually absent. Desiccation features (e.g., sun cracks) were not observed.

3. Marine origin. Marine deposition does not obviously conform with the absence of normal marine biota and the development of hypersalinity to form anhydrite nodules.

\section{Discussion}

The Site 652 Messinian succession can best be interpreted as an inward-draining, occasionally hypersaline, closed lake (Fig. 8) that was possibly periodically inundated by the sea. Reddish hematitic silts would represent wind-blown dust (Robertson, this volume). Much of the time the area was a fresh-water, or brackish, lake, and graded silts and rare organic-rich muds accumulated from suspension, possibly similar to the modern Coorong lagoons of South Australia (Von der Borch, 1976). Periodically the closed lake became saline with nodular anhydrite, and minor halite precipitation. Marine incursion cannot be ruled out.

The conglomeratic horizon records a suddenly increased clastic input, either climatically and/or tectonically controlled. In Sicily a major unconformity exists between lower and upper Messinian evaporite units, associated with tectonic tilting and reworking of the earlier evaporitic sediments (Decima and Wezel, 1973; Hsü et al., 1978) and a similar tectonic pulse could well have accelerated erosion and inundated a lake, or coastal plain with fluvial conglomerates as at Site 652 .

Petrographic study of the siliciclastic and pebbles in the Messinian unit at Site 652 points to derivation from low-grade metamorphic basement and unmetamorphosed neritic and pelagic limestones ranging in age from Jurassic (based on ?Saccacoma), to Cretaceous (on Heterohelids), to possibly Oligocene-Miocene (on benthic forams).

Source areas are unlikely to have been in Sardinia, Calabria, or the Kabilide units of North Africa, areas where metamorphic rocks predominate. Derivation locally, from the De Marchi seamount, is also ruled out, as quite different lithologies were drilled there (Shipboard Scientific Party, 1987f). More suitable is the southern Apenninic chain and/or the Sicilian Maghrebid chains where carbonate platform and associated basinal rocks of Mesozoic age are exposed. Similar lithologies were recovered from the Tyrrhenian Sea east of the Central Fault (Heezen et al., 1971; Genneseaux et al., 1986). One final problem is the source of detrital gypsum, since in situ sulfate is very minor. Possibly this calcium sulfate accumulated in adjacent areas (e.g., marginal lagoons, saline basins) and was reworked and transported out of the marginal basins.

\section{Ochreous Clastic and Evaporitic Deposition: Holes $653 \mathrm{~A}$ and $653 \mathrm{~B}$}

\section{Stratigraphy}

The upper part of a different Messinian succession was cored on the Cornaglia terrace $<1 \mathrm{~km}$ northeast of DSDP Site 132 . This terrace is underlain by a structurally deep, evaporite-bearing trough (Ryan, Hsü, et al., 1973; Figs. 1, 9). Seismic data suggest a thick basinal Messinian evaporitic sequence is present in this area (Fabbri and Curzi, 1979; Finetti et al., 1970).

The thicker of two successions, cored at Hole 653B (Fig. 9) begins with weakly calcareous powdery white gypsum interbedded with dull-red muds, then passes into brilliantly colored, yellow and red muds and clays with abundant hematite, limonite, sulfur, and sulfates. Above comes dark gray to olive-gray dolomitic nannofossil muds, interbedded with nodular and lenticular gypsum, and centimeter-thick layers of black shale. This is overlain by cloudy, laminated, "balatino" gypsum, with a 5-cmthick, calcite-cemented siltstone near the base. The Messinian succession terminates with dark gray biotite- and gypsum-bearing sands and sandy muds.

A thinner succession cored at Hole $653 \mathrm{~A}$ comprises, from the base upward (Fig. 9), calcite-cemented siltstone and calcareous mud, that then pass up into olive-gray nannofossil- and foram-bearing marly calcareous and/or dolomitic muds, with centimeter-thick gypsum layers. Above is friable gypsum with wavy laminations of probable algal origin; the Messinian succession terminates here with dark gray biotite- and gypsumbearing sandy mud and sand, as in Hole 653A. Possible correla-

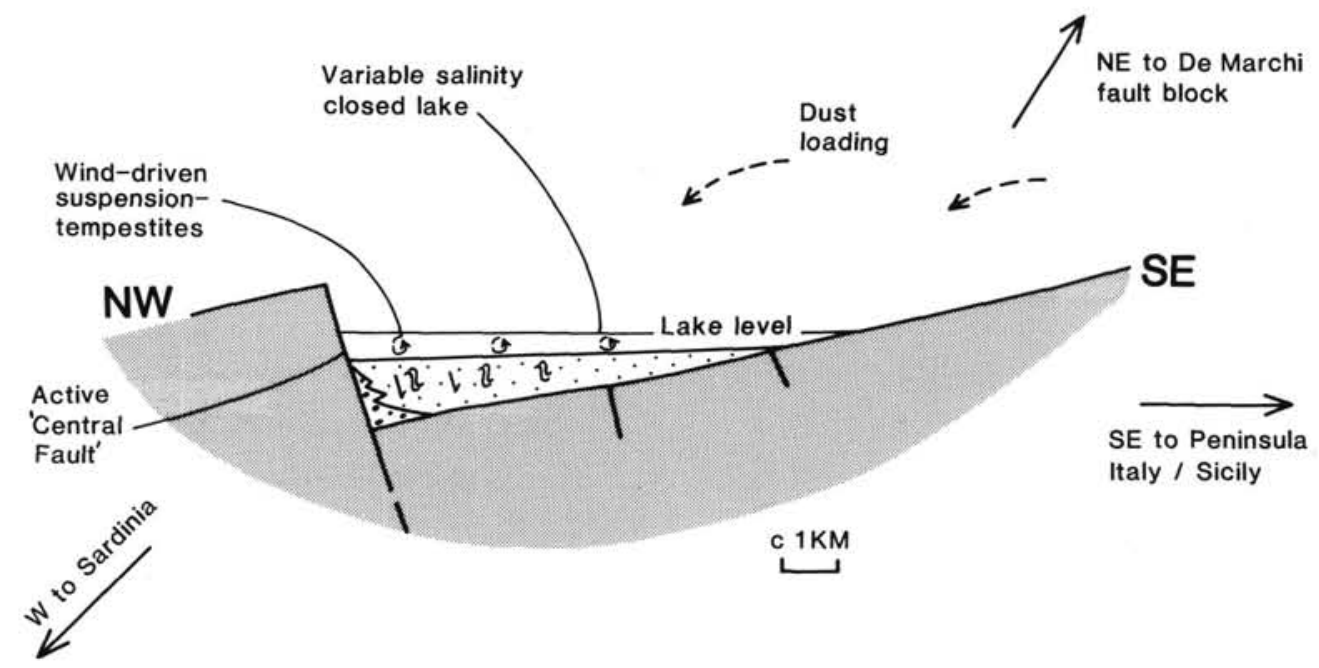

Figure 8. Schematic cross-section illustrating Messinian paleoenvironments at Site 652. See text for explanation. 


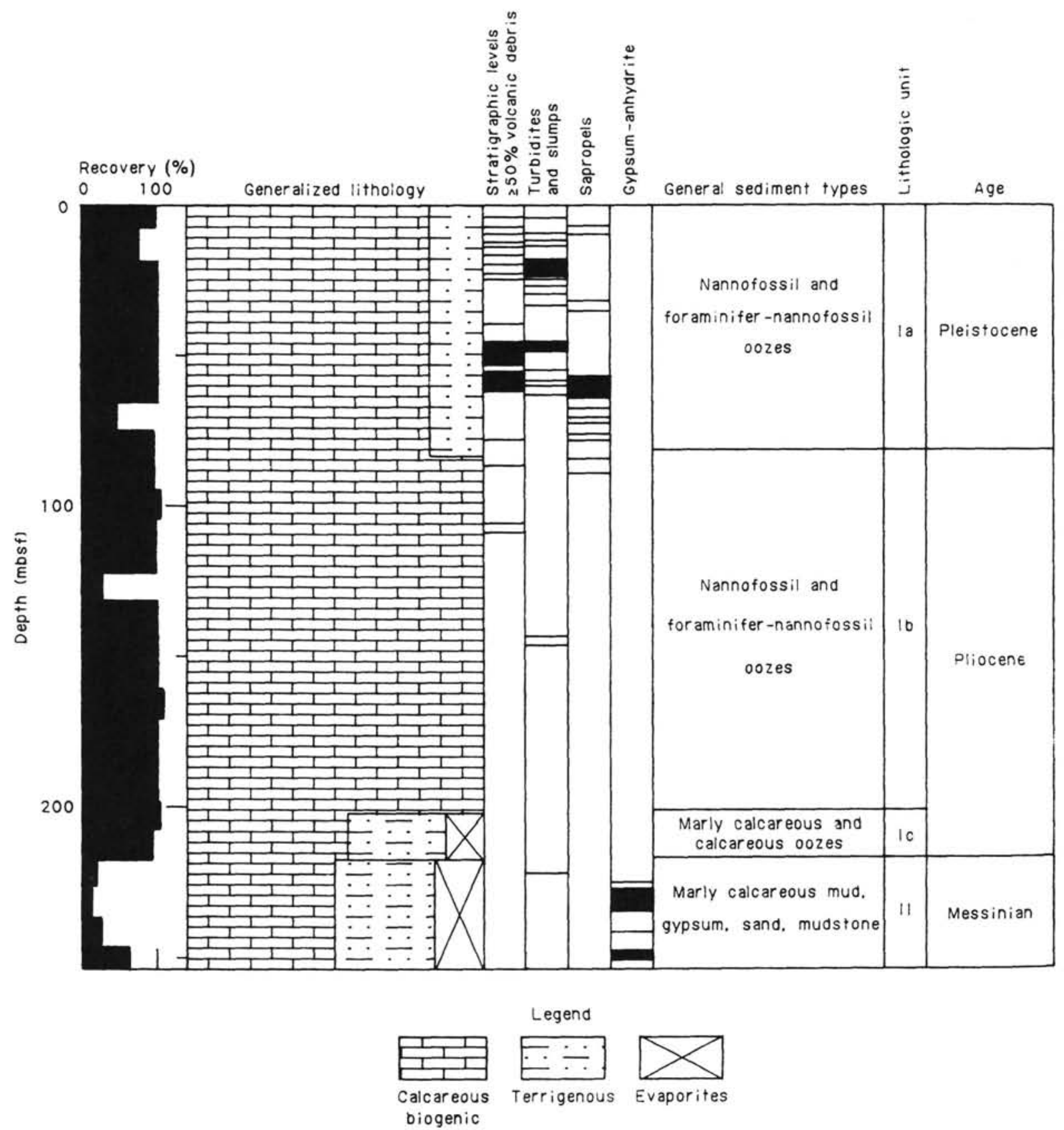

Figure 9. Composite log obtained for Site 653; after Kastens, Mascle, et al. (1987).

tion of the A and B hole is discussed in Kastens, Mascle, et al. (1987).

\section{Marginal Evaporitic Paleoenvironments}

The Messinian successions cored at Holes 653A and 653B are interpreted in terms of a progressive, but fluctuating, marine transgression, associated with sulfate precipitation. The lowest sediments cored at Hole 653B, colored muds and silts, are assumed to have been subaerially eroded from a low-relief source area. Intense in situ weathering produced abundant iron oxide. These basal sediments are also rich in sulfur. Reducing groundwaters in strongly arid weathering areas may carry large volumes of reduced iron and sulfide. Springs potentially occur where different salinity groundwaters come into contact, such as near the edge of saline lakes precipitating sulfide and iron. At
Hole $653 \mathrm{~A}$ these groundwaters probably interacted with the underlying Messinian evaporites, identified from seismic profiles. Modern environments where similar precipitation of ferruginous minerals occur are in arid marginal marine and continental settings, the best examples being restricted embayments along the Australian coast (e.g., Spencer Gulf, South Australia, and Shark Bay, Western Australia) and near continental saline lakes (e.g., Lake Tyrell, Victoria) (Kastens, Mascle, et al., 1987, and references therein).

Higher in the Tyrrhenian Messinian succession, stromatolites, interbedded with red muds (Core 107-653B-27-CC), indicate a subaqueous environment within the photic zone (e.g., Schreiber, 1982); some connection with the open sea clearly existed, possibly linking the Cornaglia basin (west of Sites 653/ 132) with the Balearic basin to the west. The overlying dark gray 
dolomitic muds, with interbedded gypsum, contain nannofossils and an impoverished planktonic foraminiferal fauna. One possibility is that in modern semi-restricted lagoonal environments, reduced dolomitic and gypsiferous muds and shales are common intertidal facies (Shearman, 1982). Coastal waters may become oversaturated with respect to aragonite, leading to precipitation, followed by replacement with dolomite after burial, when hypersaline brine circulates through sediment (McKenzie et al., 1980). Additional petrographic and geochemical (isotopic) data are needed to test this hypothesis. Presumably the gypsum grew as a crystal mush within the sediment, rather than by direct precipitation.

A transgressive setting is also suggested by the occurrence of overlying finely-laminated "balatino" gypsum at Hole 653B. This laminar gypsum resembles that at Site 654 on the upper Sardinian margin (see below) and suggests a quiet, restricted, hypersaline depositional setting.

In summary, the sediments drilled on the lower Sardinian margin at Holes 653A and -B are interpreted in terms of transgression across a clastic shoreline along a saline lake, possibly created by refilling of the Mediterranean during Messinian time. The "balatino" gypsum must have precipitated during one of the latest desiccation events before permanent marine transgression at the end of the Messinian salinity crisis, an inference based upon its stratigraphic position at Site 653. Finally, the overlying biotite- and gypsum-rich sands marking the Messinian-Pliocene transition were reworked and left by the Pliocene transgression.

\section{Basinal Deposition: Site 654}

\section{Sedimentation and Stratigraphy}

Messinian basinal facies were recovered at Site 654 on the upper Sardinian margin, on a tilted fault block overlying a $20-\mathrm{km}$ thick, stretched continental crust (Kastens and Mascle, this volume). A complete Messinian basinal evaporitic succession was drilled here, passing below into silica-rich sediments of early Messinian and Tortonian age (see above; Fig. 10).

The upper part of the Messinian sequence is medium- to fine-grained gypsiferous, dolomitic and siliciclastic sediments, comprising a soupy mixture of clay, mud, silt, and sand, interbedded with calcium sulfate-rich layers. A distinct contrast exists between soft argillaceous sediments and well cemented evaporite, with recovery strongly biased toward the hard evaporite layers. The best guide to relative lithological abundance is the drilling rate. Plotting drill-rate against time ("geolograph"; see Shipboard Scientific Party, 1987d) suggests hard evaporitic layers are present throughout the whole Messinian interval, but are concentrated in the lower part (below $280 \mathrm{mbsf}$ ), and that five main evaporitic layers are present. Comparison with drilled sections successfully recovered show these harder layers are finelylaminated "balatino" gypsum. Eleven such gypsum layers were recovered.

The inter-gypsum layers are clay, mud, silt, and rare fine sand (Plate 4,1$)$, often calcareous and rich in calcium sulfate minerals, again mostly gypsum (Plates 1,$4 ; 3,5$ ). Fine lamination is very common and thin centimeter-thick graded partings occur dozens of times over. Graded beds have sharp, sometimes scoured bases, and fine-upward from calcareous sandstone, siltstone, and silty claystones into weakly calcareous, nearly homogeneous, burrowed clay (Plate 1, 5). Partings show occasional micro-cross-lamination, small asymmetrical ripples and smallscale flaser structure. Individual graded partings are commonly separated by one or more millimeter-thick laminae composed of fine-grained gypsum.

These gypsum layers are of finely-laminated, fine-grained, alabastrine gypsum of balatino-type (Plates 1, 6; 2, 3). Several types of fine lamination, either parallel or wavy, are recognized on a millimeter-scale; first, individual fine laminations separated by fine-grained greenish claystone, or reddish claystone, commonly weakly calcareous, with occasional calcareous nannofossils and foraminifers (Plate 3,4). Secondly, there are reverse-graded partings, that pass upward into greenish clay-rich sediment; thirdly, occasional thicker-bedded and coarser-grained intervals also show reverse-grading, with gypsiferous silt passing into gypsiferous sand; numerous rip-up clasts are gypsum (Plate $2,1)$. During early diagenesis sub-vertical water-escape fractures were filled with gypsiferous silt and sand (Plate 2, 2). Selenitic gypsum concretions formed locally during diagenesis.

\section{Depositional Setting: an Evaporitic Basin}

A marine basin existed in the area prior to the Messinian salinity crisis (Fig. 11). During the initial stages of sea-level fall during early Messinian time, anoxic sediment was accumulating in an organic-rich, silled, stratified basin (see above). As sea level fell, salinity increased and finely-laminated (balatino-type) gypsum precipitated from the water column (Ogniben, 1957; Cita, et al., 1978). Similar finely-laminated gypsum was sampled in the Eastern Mediterranean Sea west of Cyprus (DSDP Sites 375 and 376; Garrison et al., 1978); it also occurs in outcrops in Sicily (Decima and Wezel, 1973), Cyprus, and other Mediterranean areas (see summary by Hsü et al., 1978). Alterations of gypsum, dolomite and dolomitic marls, resembling the sequence at Site 654 were cored in the Ionian Sea (DSDP Leg 42; Garrison et al., 1978).

In contrast to these exposures and sections, however, the occasional presence of normal marine microbiota at Site 654 points to repeated influxes of normal-salinity seawater. In response to repeated transgression cycles, dolomitic silt and mud were emplaced by gravity flow and turbidity currents. However, a dominance of siliciclastic deposition of silts and clays continuing from Tortonian time infers relative tectonic stability for the basin (Fig. 6).

The presence of millimeter-thick reversely-graded evaporite layers suggest precipitation of gypsum from high-salinity waters, followed by flushing by less saline waters; gypsum was partly dissolved during flushing, then reprecipitation produced coarser crystals when salinity again increased (Garrison et al., 1978). This model implies two major salinity variations: first, repeated small-scale, millimetric, rhythmicity locally to produce the balatino-type gypsum couplets, perhaps related to salinity variations within the saline basin (e.g., sinking of surface evaporative brine); secondly, larger scale rhythms to produce interbedded argillaceous and dolomitic sediments on the scale of meters, presumably reflecting regional periodical transgression and refilling of the Mediterranean. Possible variation in water depth, however can not be specified.

With diagenesis, alabastrine gypsum partly recrystallized, and coarse selenitic gypsum precipitated locally within mud. Sulfate-rich layers lithified relatively early during diagenesis, while unindurated argillaceous intervals underwent compaction.

\section{SEDIMENTARY EVIDENCE OF RIFTING}

Sedimentary and diagenetic structures document deformation associated with crustal extension and rifting to form the Tyrrhenian Sea in late Miocene time. Three types of structure were recognized: (1) depositional structures-gravity-deposited sediments, including turbidities and slumps; (2) early diagenetic structures-convolute lamination, neptunian dikes, and dewatering structures; (3) faults-both syndepositional and post-depositional.

Clastic sediments of probable Tortonian age, including conglomerate, cored at Site 654 document rifting, subsidence, and marine transgression, yet no evidence has recorded local insta- 


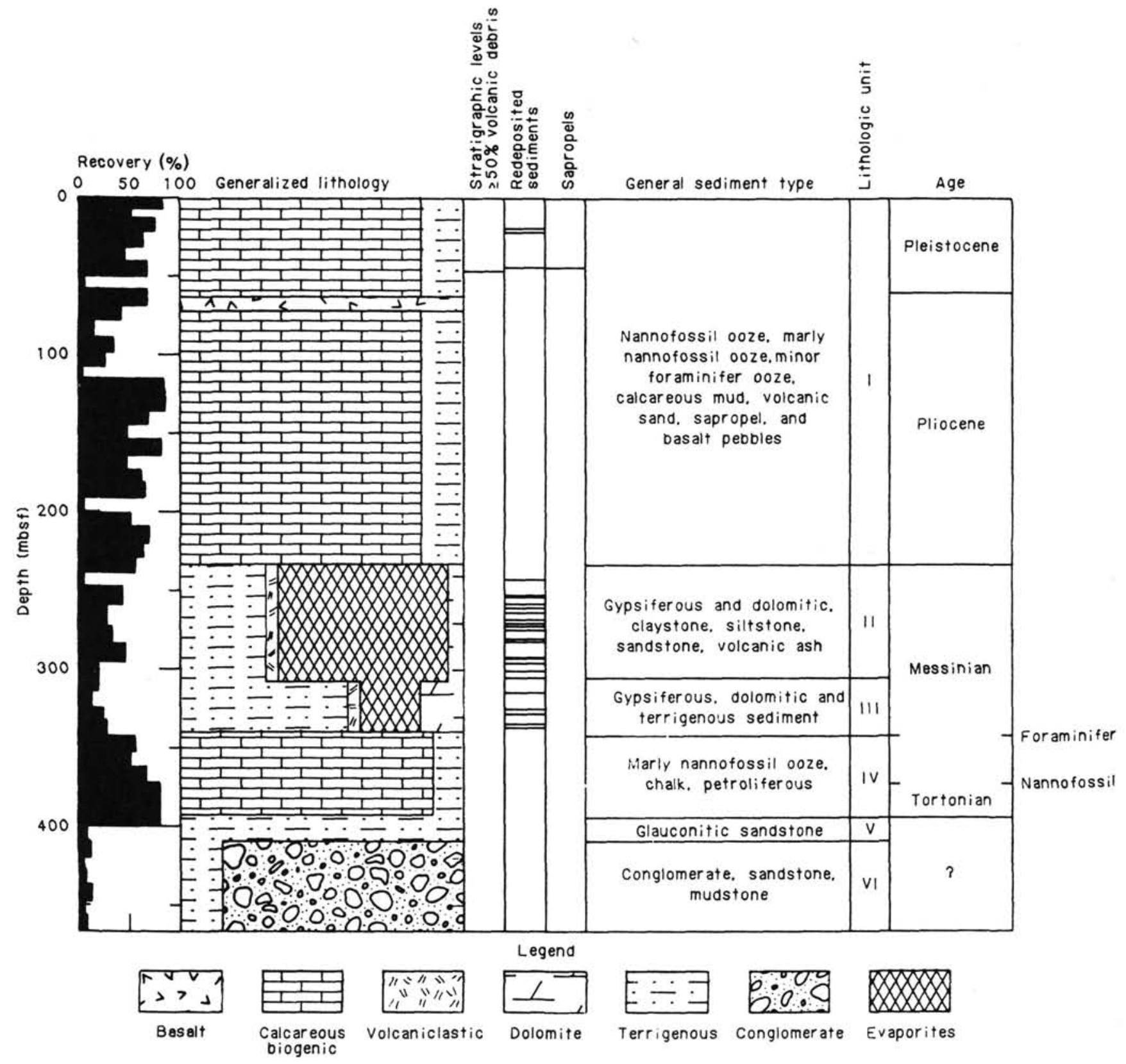

Figure 10. Lithostratigraphic summary for Site 654; after Kastens, Mascle, et al. (1987).

bility (e.g., slumping). In overlying nannofossil oozes of Tortonian and early Messinian age, intense bioturbation destroyed most depositional structures. Finely-laminated, lower to middle Messinian, organic-rich facies do document localized sediment instability by small-scale faulting, slump-folding, convolute lamination, debris flows, and intraformational rip-up clasts (Plate 1, 3). While many of the faults occur in conjugate sets with sigma 1 parallel to the drill string direction, suggesting drilling artifacts, others are frozen in rock and are thus original features (Kastens, Mascle, et al., 1987).

The overlying late Messinian gypsiferous succession at Site 654 documents some seafloor instability, by thin, less than 10 $\mathrm{cm}$ thick, clay intraclast-rich horizons; by gypsum rip-up clasts; and by dewatering structures (Plate 2,2 ). A poorly sorted microbreccia contains laminated gypsum and zeolitic muds in a fine-grained calcareous matrix (Plate 2,2). Several faults occur within laminated gypsum in the upper part of the Messinian succession; one is a small graben-like structure filled with sandy gypsum, another a normal fault (Plate 2,3 ). In the latter structure, the fault plane is irregular with spaces infilled by sparry calcite cement. Assuming a local dip to the west or west-northwest, as indicated by seismic data (Shipboard Scientific Party, $1987 \mathrm{~d})$, the orientations of slickensides suggest normal faulting downthrown to the south or southeast (trend $\mathrm{N} 40^{\circ}-85^{\circ}$ ) with a small wrench-fault component (Mascle et al., this volume; Rehault and Mascle, this volume). By contrast, little evidence of tectonic seafloor instability is recorded in the overlying Pliocene succession (see discussion below).

Much more intense sediment instability is documented on the lower Sardinian margin during Messinian time. At Site 652, up to several meter-thick intervals are chaotic deposits of slumps (Plate 2, 4), syn-sedimentary breccias, and convolute lamina- 


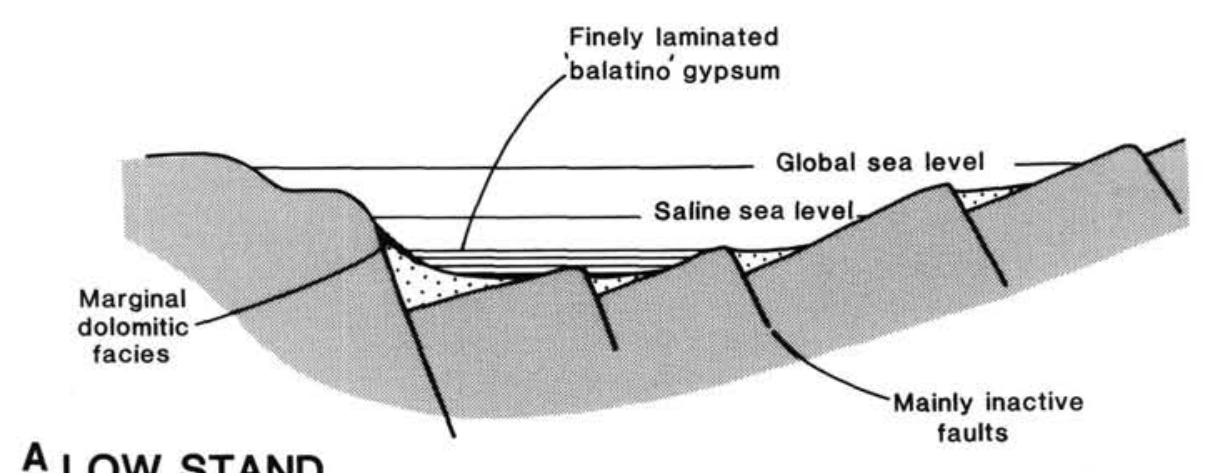

\section{A LOW STAND}

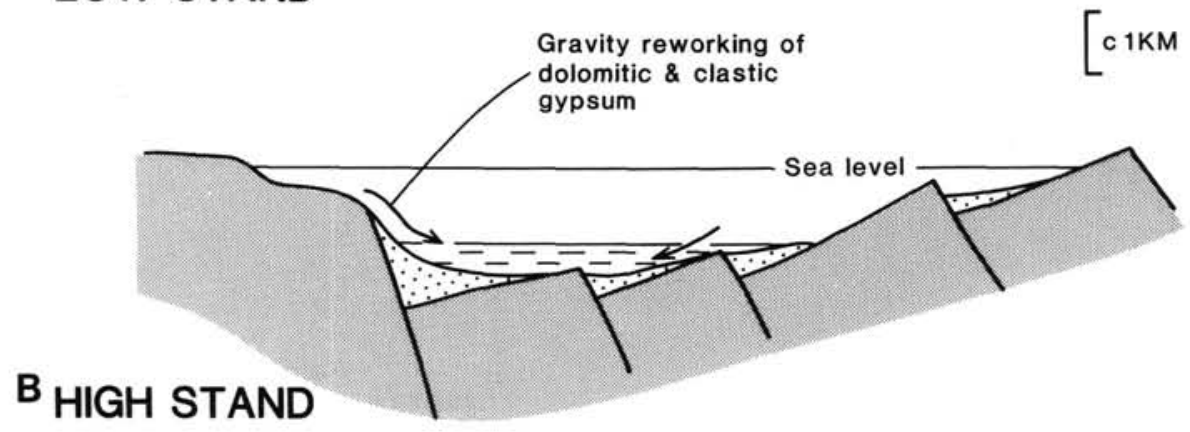

Figure 11. Schematic cross-section illustrating Messinian paleoenvironments at Site 654. A. During desiccation events. B. During marine incursions. See text for explanation.

tion. Mineral orientation (e.g., muscovite) defines a weak axialplanar fabric. Numerous faults are not drilling artifacts; assuming local dip from seismic data (Shipboard Scientific Party, 1987b), these faults are dominantly normal, downthrown to the west, with a small strike-slip component; reverse faults are present but rare (Mascle et al., this volume).

This evidence from sedimentary structures favors progressive, constant, and gentle subsidence of the upper Sardinian margin during the Tortonian, followed by increased stability during Messinian time. Slumps are rare in the Messinian succession, although post-depositional normal faults are present, possibly related to passage from stretched continental crust ("rifting") to formation of new basaltic oceanic crust ("drifting") in the adjacent Vavilov Basin. By contrast, on the lower Sardinian margin, the Messinian was marked by intense instability, probably associated with rapid subsidence. Here, sediments were repeatedly shaken by earthquakes that triggered dewatering and large-scale slumping. Slumping took place in some cases below a considerable lithostatic load, as suggested by local development of weakly developed axial-planar cleavage.

The Pliocene successions on the Sardinian margin show little sediment instability (see below), suggesting this tectonic activity associated with rifting was essentially over by early Pliocene time.

\section{MESSINIAN-PLIOCENE TRANSITION}

By the end of Messinian time, land barriers to the west were breached for the last time, and the ocean flooded back into the Mediterranean, ushering in deep marine deposition during Pliocene and Pleistocene time (Hsü et al., 1978). Miocene-Pliocene boundary sediments drilled in the Tyrrhenian Sea during Leg 107 document this transgression. Comparable facies in Sicily are represented by the Gessesso-Solifera Formation, located between the Messinian evaporite and the Pliocene Trubi marls (Decima and Wezel, 1973; Garrison et al., 1978).

\section{Transgression on a Tilting Fault Block: Holes 656A and $-B$}

A 10-m-thick interval between continental clastic and dolomitic sediments and Pliocene hemipelagic sediments was recovered on the flanks of the De Marchi seamount on the lower Sardinian margin (Fig. 2). Here at Hole 656A, the base of this transitional interval is marked by brown fossiliferous oozes rich in iron-oxide with rare slump structures, followed upsection by alternations of nannofossil ooze, foram-rich nannofossil ooze, and calcareous silty claystone, locally well-indurated. This succession becomes finer-grained upwards; basalt sediments are multicolored, yellowish, brownish, reddish, olive, and gray, thinlylayered oozes, burrowed with scattered forams. At nearby Hole $656 \mathrm{~B}$, poor recovery and slumping of late Pliocene or younger age obscured the Messinian-Pliocene transition.

This sedimentary succession we interpret as continental deposits that accumulated on the flanks of the tilted De Marchi seamount during Messinian time (Fig. 6); during transgression lateritic weathering products were deposited and reworked, followed by slumping related to marine sediment draping and/or tectonically-controlled subsidence near the boundary with oceanic crust in the Vavilov Basin.

\section{Transgression of a Lake: Site 652}

We interpret the depositional environment of Messinian sediments at Site 652 on the lower Sardinian slope as a closed lake of variable salinity. A distinct and thin $(40 \mathrm{~cm})$ transitional interval, present between Messinian sandy and silty sediments and the first occurrence of marine planktonic foraminifera, is marked by repeated $0.5-4.0-\mathrm{cm}$-thick layers of clay and mud, that become more brightly colored upward; grays give way, in turn, to greenish-gray and light-gray, reddish-gray, to strong brown and finally to red colors (Fig. 7). The reddish color wanes upward over several meters, until the base of the early Pliocene MPI1 
zone. Average carbonate content in marine muds more than doubles from the bottom to the top of the transitional interval.

In contrast to steep slopes inferred on the flanks of the De Marchi seamount (Holes 656A and -B, see above), a low-gradient, nearly flat, lacustrine plain was present at Site 652 , as inferred from the uniformly-bedded fine-grained sediment beds in the transitional interval; in such a setting, marine transgression would have been rapid. The reddened sediments again reflect weathering and reworking of sediment from the Messinian landmass. Fine-grained iron-oxide material was resuspended by the advancing seas and mixed with Pliocene marine sediments.

\section{Transgression of a Marginal Setting: Holes 653A and -B}

The depositional environment for late Messinian sediments cored at Holes 653A and -B on the lower Sardinian margin was interpreted as the littoral of a closed saline lake, sabkha, and/or hypersaline sea. Calcareous fossiliferous clay near the top of the Messinian succession at Hole $653 \mathrm{~A}$ is overlain by an $11.5-\mathrm{m}$ thick transitional interval (Fig. 6). A 70-cm-thick, dark-gray sand forms the basal sediment in the transitional sequence. This sand contains abundant biotite and detrital gypsum crystals. Similar sands were recovered at Hole 653B and Site 132 (Leg 14; Ryan, Hsü, et al., 1973). At Hole 653A the sand shows parallel lamination, while at Site 132, cross-bedding was noted, but this appears to result from drilling disturbance. Upsection, at Hole $653 \mathrm{~A}$, an interval interpreted as drilling breccia is followed by a further thin layer of gypsum- and biotite-bearing sand, passing up into gray calcareous mud and marl, then into mud and olive brown, dark brown, and reddish mud and marl (Shipboard Scientific Party, 1987d; subunit 1c). The contact between the reddish muds and typically Pliocene gray muds, is marked by a thin interval of dark-gray mud, while at Hole 653B reddish muds pass abruptly into Pliocene gray muds.

The area farther west on the upper Sardinian margin (Fig. 2) was already a marine basin by late Miocene time, based upon paleoenvironment interpretation from Site 654 sediments, thus the Pliocene transgression apparently proceeded eastward from the upper margin toward the Cornaglia Basin. Biotite and detrital gypsum were eroded from potassic igneous and/or metamorphic rocks, the latter presumably exposed on a basement high about $20 \mathrm{~km}$ east of Site 653 inferred from seismic data. As sea level rose, these sands, in addition to iron oxide particles were reworked, perhaps on a beach; these transgressive sand deposits were then overlain by Pliocene hemipelagic marls and oozes.

\section{Transgression in a Basin: Site 654}

The Messinian marine basin flooded by the Pliocene sealevel rise on the lower Sardinian margin (Site 654) was hypersaline. Messinian gypsum is overlain by $2.5 \mathrm{~m}$ of burrowed foraminiferal and nannofossil oozes with only two thin $(2-5 \mathrm{~cm}$ thick) olive-brown marl layers (Fig. 10), suggesting minimal reworking during transgression.

\section{PLIO-PLEISTOCENE SEDIMENTATION AND PALEOENVIRONMENTS}

Late Miocene-early Pliocene rifting elongated the Tyrrhenian Sea to the south-east (Kastens, Mascle, et al., 1987). On the upper Sardinian margin, the stratigraphic succession at Site 654 indicates that a deep marine rift basin developed by late Tortonian time, while the lower Sardinian margin area still remained highstanding and contiguous with the Italian landmass. Messinian sediments cored at Site 652 on the lower Sardinian margin show much evidence of instability and subsidence by slumps, mud breccias, etc., that preceded final continental break-up. By early Pliocene time, extension in the southeast area of the central Tyrrhenian Sea finally separated Calabria and Sicily from Sardinia, with the creation of a new basin floored by young oceanic crust (Kastens, Mascle, et al., 1987; Kastens and Mascle, this volume; Figs. 1, 2).

A single overall depositional regime prevailed during Pliocene and Pleistocene time in the Tyrrhenian Sea. Three sites were drilled on this young oceanic crust (Figs. 1, 2): Site 655 , sited on a basaltic high, the Gortani Ridge, located close to the inferred continent-ocean boundary in the northwestern Vavilov Basin; Site 651, drilled nearby on an axial swell in the centre of the Vavilov Basin; and Site 650 located further southeast, on the western edge of the Marsili Basin (Kastens, Mascle, et al., 1987). At all three sites, the depositional regime was similar, with open-marine hemipelagic sedimentation.

\section{Igneous Basement-Sediment Relations}

Sediments associated with igneous basement contribute to a description of the tectonic and paleoenvironmental setting of ocean crust genesis in the Tyrrhenian Sea. Circumstantial arguments, discussed by Kastens, Mascle, et al. (1987), suggest basaltic crust in the Marsili Basin formed about 2 Ma later than the igneous crust of the Vavilov Basin. Sediments were recovered within igneous basement rocks in the Vavilov Basin at Site 651 , from within Gortani Ridge basalts along the western rim of the Vavilov Basin at Site 655, close to the foot of the lower Sardinian margin, and small volumes of sediment were found intercalated with basaltic lavas in the Marsili basin at Site 650 .

\section{Sediments Associated With the Vavilov Basin Basement: Site 651}

Drilling the axial swell of the Vavilov Basin recovered small volumes of sediment within a diverse suite of mafic, ultramafic, leucocratic intrusive, and basic extrusive igneous rocks (Bonatti et al., this volume; Fig. 12). In general, serpentinized lherzolite is overlain by basalt, basaltic breccia, dolerite, metasediments, and metadolerite, then by more basalt. Based mainly on mineral chemistry, the peridotites are identified as relatively undepleted mantle asthenosphere (Bonatti et al., this volume). Although strongly altered, the major and trace element chemistry of the basalts is of MORB-type and/or alkaline type (Boivin, this volume; Bonatti et al., this volume).

The serpentinized peridotite is overlain by $30 \mathrm{~m}$ of basalt and basalt-cemented breccia. A $70-\mathrm{cm}$-thick pebbly and sandy layer, normally graded, is probably an artifact of drilling. Above is 3.5 $m$ of unsorted basalt-derived breccia cemented by sparry calcite (Plate 2, 6). Angular fragments of chilled and unchilled basalt and hyaloclastite are set in a matrix of medium to coarse microspar and fine-grained hyaloclastite, partly replaced by calcite. A calcite cement often rims individual basalt clasts. In one case $(107-651 \mathrm{~A}-55 \mathrm{R}-1,100-102 \mathrm{~cm})$, the breccia contains millimeter-sized clasts of siltstone with small mica laths. In other breccia samples, basaltic clasts are partly replaced by chalcedonic quartz, and ferromagnesian phenocrysts by sparry calcite. In places, the replacive spar is in optical continuity with the interstitial cement.

Basaltic breccia is overlain by altered basalt, interpreted as a thin flow, then by $1.2 \mathrm{~m}$ of carbonate-cemented, basalt-derived, breccia. Strongly altered basalt above this includes further small amounts of carbonate-cemented basaltic breccia. An isolated clast of micritic limestone from this interval, at $465 \mathrm{mbsf}$, was found to contain planktonic foraminifera tentatively identified as Globorotalia crassiformis, suggestive of a middle Pliocene age ( $3 \mathrm{Ma})$.

Basalt-derived breccias are overlain by white leucocratic rocks of probable mafic intrusive origin (Shipboard Scientific Party, 1987a). A 30-cm-thick intercalation of yellow to brownish finegrained dolostone, similar to the basal sediments above the ig- 


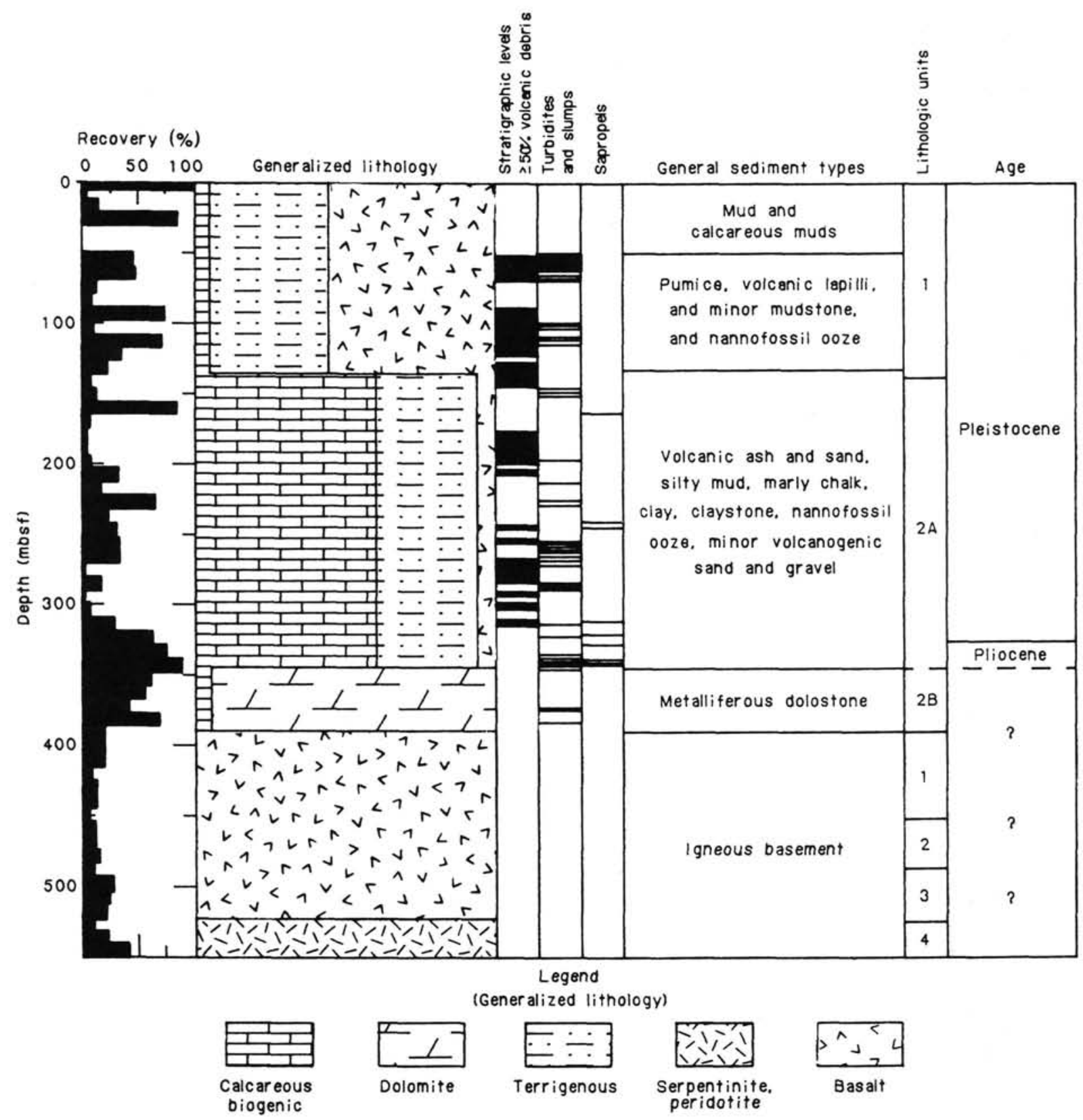

Figure 12. Generalized lithological column, showing the main lithologies described and subdivision into units at Site 651 . In the stratigraphic column, the width of each vertical division is proportional to the percent of the indicated lithology recovered in that lithostratigraphic unit; after Kastens, Mascle, et al. (1987).

neous basement (see below), contains micrite, granules of opaque iron-oxide, and scattered recrystallized planktonic foraminifera (Plate 4, 2, 3).

Sediment intercalated within massive basalts forms the upper portion of this basement complex, at the base of the overlying sediment cover. The igneous-sediment contact was not recovered although light reddish-brown dolomite was formed filling cracks in the uppermost basalt cored.

\section{Faulting and Oceanic Crustal Genesis}

Strong faulting exposed basalt and peridotite, probably derived from basalt and an upper mantle wedge that protruded to the seafloor near the axis of the Vavilov Basin, producing breccias either by shearing process or by accumulation of submarine screes along fault scarps. Sediment is an open marine pelagic carbonate, with fine-grained terrigenous components. Pelagic carbonates accumulated on erupted basalt flows, coupled with subsurface sill intrusion. Sparry calcite cement in breccias precipitated from hydrothermal fluids; mafic igneous rocks were altered to a white leucocratic rock (Bonatti et al., this volume).

Bernoulli et al. (1978) described multiple stages of internal carbonate sediment infill and carbonate cementation in basaltic breccias from the Vavilov Basin at Hole 373A, where oxygen and carbon isotopic data indicate a low-temperature diagenetic origin for the carbonate cement. Unlike Site 651 , small volumes of ferruginous dolomite were also recovered, but no ultramafic clasts at Hole 373A.

Sedimentary breccias that accumulated along fault scarps are reported from a wide range of oceanic settings, particularly along rifted spreading ridge segments (Bonatti et al., 1974) and 
transform faults; similar breccias are known from ophiolite complexes, for example the Ligurian Apennines (Cortesogno et al., 1978; Barrett and Spooner, 1977; Lemoine, 1980) and the Arakapas Fault of the Troodos Complex in Cyprus (Simonian and Gass, 1978). The breccias recovered at Site 651 share many of these features and are believed to be talus rather than tectonic in origin.

\section{Basalt-Sediment Relations on a Seamount: Site 655}

The upper part of the Gortani Ridge (Fig. 13), in a sequence of pillowed tholeiitic basalt that, on paleomagnetic and biostratigraphic data, erupted during the period $\sim 3.4-3.6 \mathrm{Ma}$ (based on nannofossils, NN15), corresponding to the reversed polarity event at the top of the Gilbert magnetic epoch (Channell and Torii, this volume).

Three types of sediment were recorded within the pillow basalt: (1) fine-grained micritic limestone with a thin $(\leq 1 \mathrm{~cm})$ baked contact with basalt containing millimeter-sized clasts of palagonite and a reddish crust; (2) interstitial sediment, now fine-grained limestone, within steeply-dipping, 1-mm to 2-cmthick cracks in the basalt where baking/chilling at the lava-sediment contact is not seen (Plate 4, 4); (3) thin, millimeter-thick carbonate veins.

\section{Pelagic and Hydrothermal Infill}

Seismic evidence indicates sediment ponding against the Gortani Ridge (Kastens, Mascle, et al., 1987); paleomagnetic inclination data suggest marked post-eruptive tilting has not taken place (Channell and Torii, this volume). Thus, the Gortani Ridge seems to be a linear basaltic ridge that underwent passive subsidence after formation. Successive basalt flows were covered with a thin veneer of pelagic carbonate. Post-eruption, steeplydipping fractures developed, and pelagic carbonate percolated downward into these fissures. Later, thin calcitic veins precipitated from low-temperature hydrothermal solutions.

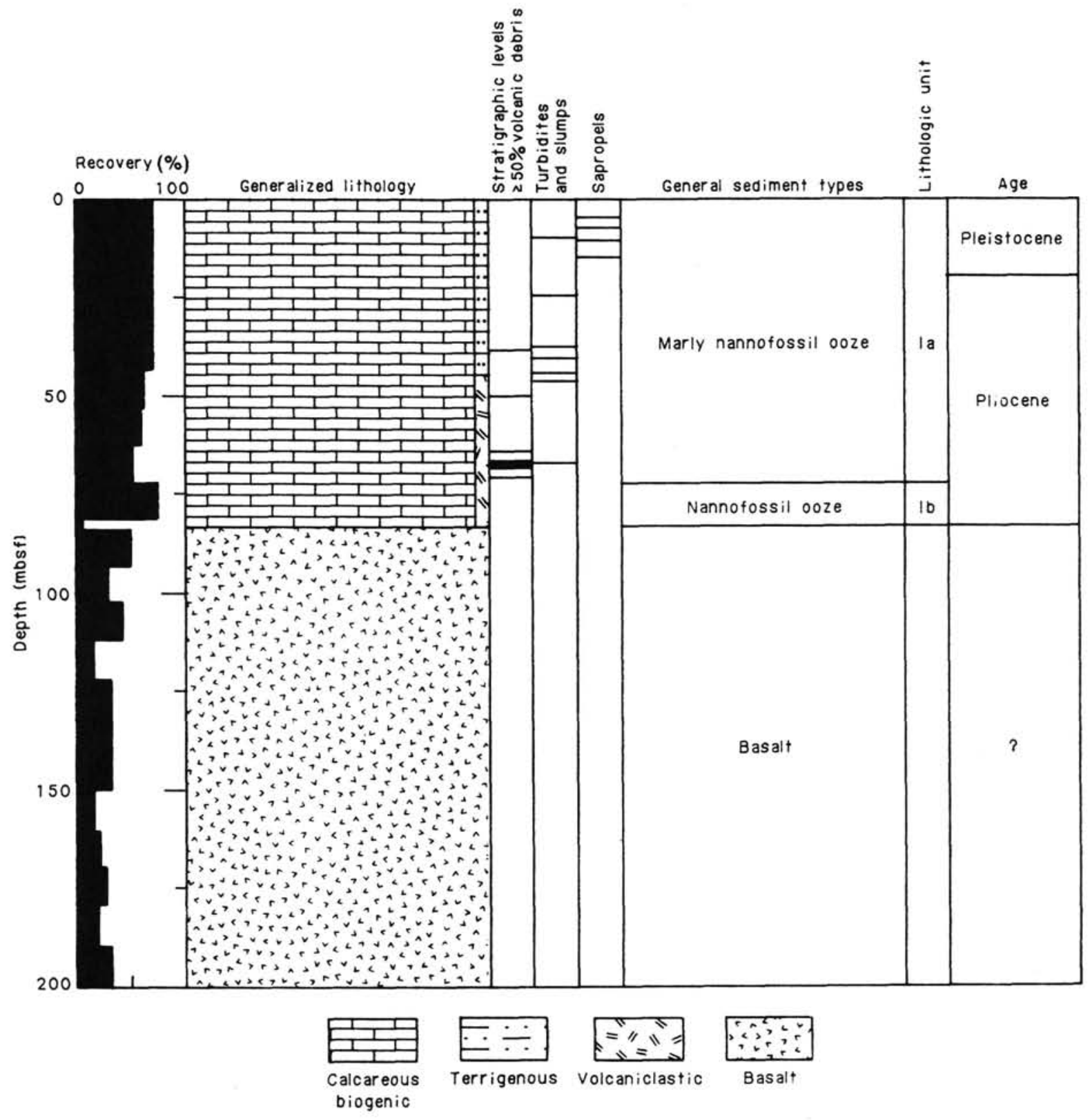

Figure 13. Composite lithologic column of Site 655; after Kastens, Mascle, et al. (1987). 
Interstitial carbonate sediment from similar settings from within pillow basalt are known in both modern and ancient settings. Pelagic carbonate is present today, for example, draping and infilling pillow basalt on the Mid-Atlantic Ridge (Ballard and Moore, 1977). Interstitial pelagic carbonate in ancient settings in land exposures include the Olympic Peninsula, Washington (Garrison, 1972), the Antalya Complex, southwest Turkey (Robertson and Woodcock, 1981), and other Tethyan ophiolite-related settings (Robertson and Boyle, 1983).

\section{PLIOCENE AND PLEISTOCENE SEDIMENTATION}

Pliocene and Pleistocene sediment sequences were recovered from all sites drilled in the Tyrrhenian Sea (Figs. 1, 2). In general, sedimentation reflects an interaction between seafloor topography, and the input or dispersal of terrigenous, volcaniclastic, and pelagic debris. The Pliocene of the upper Sardinian margin (Site 654) is interpreted as a post-rift drape, while on the lower Sardinian margin (Site 652), seismic profiles suggest the syn-rift to post-rift contact lies within the lower Pliocene sedimentary sequence (Kastens, Mascle, et al., 1987). Diagenesis has significantly modified sediment mineralogy, especially in sediments overlying young oceanic-type crust in the Vavilov and Marsili Basins, where heat flow is presently highest. Within an essentially constant pelagic sedimentary flux during the Pliocene and Pleistocene, basalt, dolomite (above the oceanic-type crust), volcaniclastic sediments, organic carbon-rich layers, and sapropels also are prominent lithologies. Sedimentation rates in the deep basins (Vavilov and Marsili Basins, Sites 651 and 650) increased sharply from $\sim 3-6 \mathrm{~cm} / 1000 \mathrm{yr}$ during the Pliocene, to $27-95 \mathrm{~cm} / 1000 \mathrm{yr}$ in Pleistocene time (Kastens, Mascle, et al., 1987).

\section{Pliocene Deposition of Pelagic Sediment}

Pliocene sedimentation of pelagic oozes is well-documented on the Gortani Ridge basement high (Site 655), along the eastern margin of the Vavilov Basin (Fig. 1). Here, late Pliocene succession is homogeneous foraminifer-rich nannofossil ooze, with several centimeter-thick, often colored, pinkish to reddish banded intervals. There is a progressive downhole change in color from pale yellow to brown as the underlying basaltic basement is approached. Black specks of iron monosulfide ("hydrotroilite") also increase toward the base of the succession (Fig. 14). Sporadic volcaniclastic layers are present.

Similar foraminiferal and foraminiferal-nannofossil oozes of Pliocene age were cored on the Sardinian margin. At Holes $653 \mathrm{~A}$ and $653 \mathrm{~B}$, these sediments are burrowed, and a few thin foraminiferal sand and mud layers occur. Elsewhere on this margin (Site 652), foraminiferal and nannofossil oozes contain abundant, but scattered, volcanic glass, graded volcanic sands, and rare sapropels. Pyrite is locally abundant, particularly on framboids within foram tests. Four sandy mudstone layers appear to correspond to an interval of decreased sedimentation rate (Shipboard Scientific Party, 1987b). On the upper Sardinian margin, at Site 654 , the Pliocene interval comprises nannofossil ooze with scattered planktonic foraminifera, and pyrite is abundant as either finely disseminated euhedral crystals or as framboids in foraminifer tests.

Contrasting dolomitic successions of late Pliocene age were recovered from immediately above the oceanic-type crust of the Vavilov and Marsili Basins. At Site 650 in the Marsili Basin, these sediments are a burrowed foraminiferal and nannofossil chalk interbedded with thin calcareous siltstone and mudstone and rare sapropels (Fig. 15; Plate 5, 1, 2). In the Vavilov Basin at Site 651 , above a dolomite-rich succession, sediments consist almost entirely of nannofossil ooze with a few calcareous muddy layers, pebbly mudstone, and occasional slump structures (Fig. 12).

\section{Calcareous Pelagic Deposition}

During most of Pliocene time, the entire Tyrrhenian Sea was characterized by deep-water carbonate pelagic deposition. Foramrich layers are attributed to fluctuations in surface water productivity, downslope gravity reworking, and/or winnowing by bottom currents. For instance, sandy intervals recovered at Site 652 correspond to an interval of reduced sedimentation rate, an indication that fraction currents allowed a coarse-fraction concentration. Burrowing indicates well-oxidized bottom waters. Pyrite is abundant at Site 652, perhaps reflecting accumulation and burial of organic matter on the upper Sardinian margin. By contrast, in the Vavilov and Marsili basins, Pliocene hemipelagic deposits are distinctly more muddy, reflecting a relatively greater input of terrigenous and volcaniclastic material. These Pliocene successions generally resemble those of the Tyrrhenian Sea at Site 132 (Ryan, Hsü, et al., 1973; Nesteroff, 1973; Nesteroff et al., 1973) and Site 373 (Hsü, Montadert, et al., 1978), and more generally, on-land exposures, such as the Trubi marl of Sicily (e.g., Rio et al., 1984).

\section{Pleistocene Deposition of Pelagic Sediment}

The Pliocene-Pleistocene boundary in the Tyrrhenian Sea is not characterized by a marked lithological change. On the Gortani Range (Site 655, Fig. 13), the Pleistocene succession is characterized by marly nannofossil oozes and nannofossil oozes with abundant planktonic foraminifera. $\mathrm{CaCO}_{3}$ ranges from $42 \%$ to $66 \%$, with an average of $54 \%$ (Shipboard Scientific Party, 1987e). A <1-mm-thick crust, enriched in iron and manganese, occurs in some of the marly nannofossil oozes. Sapropels and detrital sand layers are also present.

At Holes $653 \mathrm{~A}$ and $653 \mathrm{~B}$, on the lower Sardinian margin (Fig. 9), Pleistocene sediments are mainly nannofossil and foraminiferal-nannofossil oozes, with scattered pteropod shells; $\mathrm{CaCO}_{3}$ increases downcore, from an average of $40 \%$ near the surface to an average of $60 \%$ lower in the succession (Shipboard Scientific Party, 1987c). Volcaniclastic layers are common. Elsewhere on the lower Sardinian margin, such as at Site 652 (Fig. 8), the Pleistocene is distinctly more muddy reflecting a greater terrigenous influx, with an average carbonate content of only $22 \%$. On the upper Sardinian margin, burrowed nannofossil oozes are interbedded with carbonate muds, sapropels, and volcaniclastics.

At sites overlying oceanic-type lithosphere, in the Marsili and Vavilov Basins (Figs. 12, 15), Pleistocene-age pelagic sedimentary material is mixed with coarser-grained volcaniclastic and terrigenous material.

\section{Comparison with Onshore Basins of Mainland Italy}

In general, Plio-Pleistocene subsidence and sedimentary histories are similar throughout the eastern Sardinia margin (Sites $654,653,132,652,656)$; thicknesses range from only 220 to 190 $\mathrm{m}$ for a distance of $>200 \mathrm{~km}$. This situation abruptly changes in the deepest and more easterly sites, 651 and 650, where Pleistocene subsidence rates are extremely high (Kastens, Mascle, et al., 1987; see "Biostratigraphy" sections), up to more than 50 $\mathrm{cm} / 1000$ yr. This is comparable to the "perityrrhenian basins" of Selli (1974) and Fabbri et al. (1981), sedimentary basins located along the eastern Tyrrhenian margin, both on land and offshore. For example in the Paolo Basin off northern Calabria, average sedimentation rates for Plio-Pleistocene are $\sim 100 \mathrm{~cm}$ / $1000 \mathrm{yr}$, with extremely strong subsidence (Barone et al., 1982). The same applies for the Sek basin in Campania, a fault controlled depocenter with Plio-Pleistocene downthrows of some kilometers (Sartori et al., 1987a). All these basins contain abundant interbedded volcaniclastic, coarse clastic, and turbiditic deposits. 


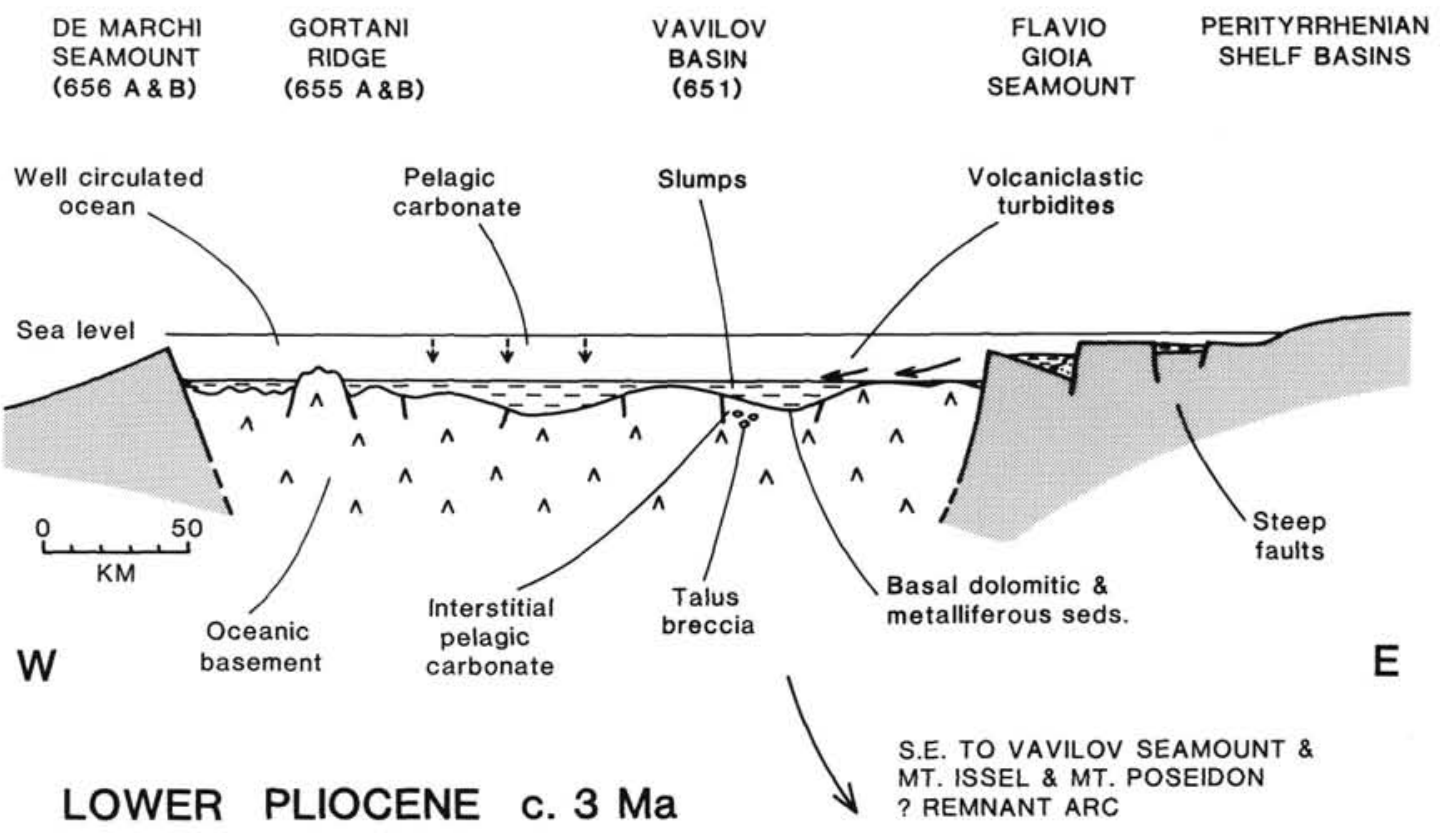

Figure 14. Schematic cross-section illustrating early Pliocene paleoenvironments in the Vavilov Basin. See text for explanation.

\section{Pliocene Basal Dolomitic and Metalliferous Sediments}

At the three sites located on oceanic crust, basal sediments are dolomitic and appear $\mathrm{Fe}$ - and $\mathrm{Mn}$-rich by their red-brown colors. The thickest sequence, $40 \mathrm{~m}$, was cored at Site 651 in the Vavilov Basin (Fig. 12). Although the lava-sediment contact was not recovered, the basal dolostone is brightly colored, bioturbated, with manganese oxide disseminations ("dendrites") and evidence of sediment instability. Colors become more subdued upward. The uppermost $1 \mathrm{~m}$ of these dolomitic sediments contain microfossils that indicate a late Pliocene age $(\sim 2.0 \mathrm{Ma})$ (Kastens, Mascle, et al., 1987). Similar dolostones overlie the basaltic basement in the Marsili Basin, at Site 650 (Fig. 15, Plate 2,5), where they are greenish $(10 \mathrm{~cm})$, with red and brown hues dominating upsection. At Site 655 (Fig. 13), basal dolostones $5 \mathrm{~cm}$ above the basaltic basement are dark brown.

Calcareous nannofossils are poorly preserved in these dolostones. Scanning electron microscopy shows euhedral dolomite rhombs $2-20 \mu \mathrm{m}$ in size. Both major- and trace-element data and carbon and oxygen isotopic data suggest formation related to relatively low-temperature hydrothermal processes (Robertson, this volume; McKenzie et al., this volume).

\section{Volcaniclastic Sedimentation in the Marsili Basin: Site 650}

Pleistocene volcanism of the Eolian Islands is documented by Site 650 , located in the southeastern of two deeps within the Marsili Basin (Figs. 1, 15); the site was chosen to avoid volcanics related to the nearby Marsili seamount. The nature of the basaltic basement drilled at Site 650 is important since the chemical composition of many ophiolite complexes, including the Troodos Complex, Cyprus, and Semail Nappe, Oman, suggests genesis above subduction zones (Pearce et al., 1984). However, the basaltic basement rocks recovered at Site 650 are very altered (Kastens, Mascle, et al., 1987) and may not allow any tectonic setting to be specified. Volcaniclastic turbidities were identified by normal size-grading, massive sands often having layers of light and dark sands and/or cross-bedding, alternations of sands and muds, erosional lower contacts, and dis- placed sedimentary components such as pteropod shell fragments, foram tests, or woody debris.

Volcaniclastic sediment is virtually absent from the Pliocene interval drilled at Site 650 in the Marsili Basin (Fig. 15). Above $606 \mathrm{mbsf}$, nannofossil ooze gives way to calcareous mud, rich in fine-grained vitric particles. There are, in addition, numerous normally-graded turbidities, mostly less than $10 \mathrm{~cm}$ thick, that contain abundant silt-sized volcanic material. Volcaniclastic turbidities become generally more abundant upward, reaching a maximum in the upper $68 \mathrm{~m}$ of the succession where they are dominated by undevitrified pumice and volcanic glass (Plate 4, 5 ), ranging from colorless to greenish and brownish, with admixed terrigenous sediment (Plate 5, 5).

Prominent here is a thick volcaniclastic debris flow. It occurs at both this site and at Site 651 ; it is the only volcaniclastic unit readily correlative between these two sites. Glass chemistry corresponds to that of the Y-5 tephra deposit so prominent in eastern Mediterranean late Pleistocene pelagic sections.

The bathymetry of the modern day channels in the area suggests input of volcaniclastic sediment to the deep basin from, dominantly, the Eolian Islands but also from the CampanianRoman area, and possibly the perityrrhenian basins (Fig. 16). The refractive indices and the chemistry of the volcanic glass indicate a mainly calc-alkaline composition (McCoy and Cornell, this volume), comparable with the Eolian Islands and offshore, but with some admixture of the more potassic volcanics from the central and southern Apennines (Barberi et al., 1974, 1978; Villari, 1980; Beccaluva et al., 1981, 1982; Rehault et al., 1977).

At Site 650 the volcaniclastic sediment appears at the end of the Pliocene and is abundant in the late Pleistocene interval. In situ pyroclastic ash, including "Pele's hair," is rare, since much of the volcanic sediment was redeposited by turbidity currents. Only 5 tephra layers, relative to 156 turbidities, between Cores 1 and 14 , were found; it is estimated that $59 \%$ of the succession is displaced, equivalent to one turbidite, on average, every 1,538 years.

Radiometric dating confirms only Pleistocene volcanic activity in the Eolian islands (Barberi et al., 1974, 1978; Beccaluva et al., 1982, 1985). The absence of a well-developed older volcanic 

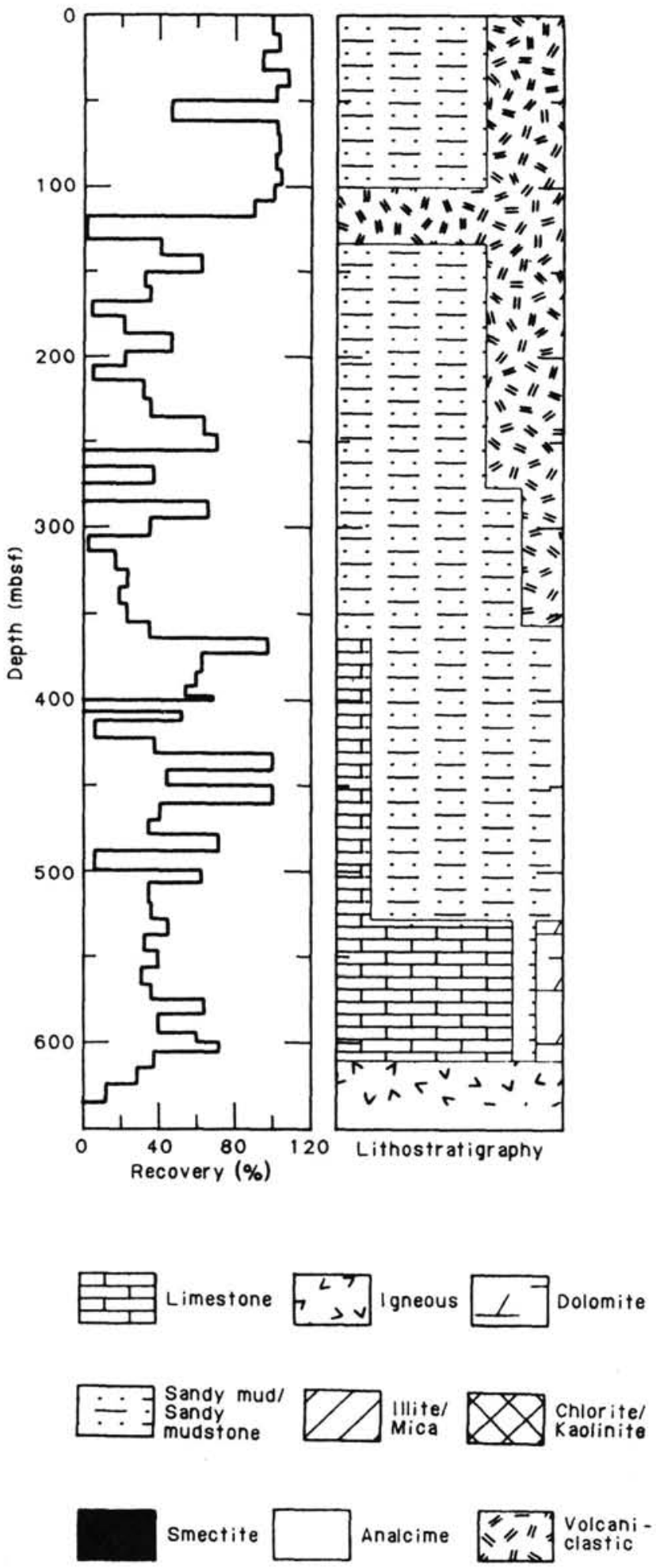

Figure 15. Generalized lithological column and the recovery at Site 650, Marsili Basin; after Kastens, Mascle, et al. (1987).

arc is surprising in the hypothesis of the Tyrrhenian Sea as a Miocene-Pliocene back-arc basin formed above a subduction zone (Malinverno and Ryan, 1986; Kastens, Mascle, et al., 1987). Possibly, such a volcanic arc existed but was submerged (Sartori et al., 1987a) or later rifted away and left as a remnant arc, comprising the M. Issel-M. Glauco saddle separating the Vavilov and Marsili Basins (Kastens, Mascle, et al., 1987).

\section{Volcaniclastic Sediment in the Vavilov Basin: Site 651}

Contrasting successions of volcaniclastic sediments were cored at Site 651 in the Vavilov Basin (Figs. 1, 12). Volcaniclastic sediment first appears immediately above the igneous basement as a thin, feldspathized, volcanic ash within dolostone. Above this, within the upper Pliocene interval, there are occasional thin, less than $5 \mathrm{~cm}$ thick, turbiditic silts, composed mainly of altered volcanic glass and pumice (Plate 5,3 ). Volcaniclastic sediments are much more abundant in the Pleistocene in the top 20 cores. At least 93 turbidite layers were counted in the Plio-Pleistocene succession, typically averaging $7 \mathrm{~cm}$ thick, equivalent to one event every $240,000 \mathrm{yr}$ on average. On the basis of radioactivity legs, volcaniclastic sediment is inferred to be abundant above 309 mbsf. Volcaniclastic sediment is occasionally cemented by white opaline silica (Plate 5, 4). Gravel contains pebbles of extrusive rocks, containing potassium feldspar phenocrysts and rare grains of schist and marble. As at Site 650, the Pleistocene succession contains much volcanic glass, ranging from fresh (Plates 4 and 6) to very altered (Plates 5 and 6).

Bathymetry of modern-day channels adjacent to Site 651 suggests transport paths for volcanic sediment from the adjacent Italian mainland, via turbidities and/or mass-flows (Fig. 16). Glass chemistry and U/Th ratios (from downhole logs) suggest derivation from the northern part of the Roman province (Broglia et al., this volume); glass chemistry also indicates an Eolian provenance for vitric fragments. Also prominent at this site is a volcaniclastic debris flow correlative to the extrusive Y-5 tephra (discussed in previous section). Clastic petrology at Site 651 indicates volcanic and low-grade metamorphic source rocks. Nesteroff et al. (1973) also noted volcanic source areas in the Apennines and the Eolian arc at Site 132 and conclude in favor of an origin of tephra at this site mainly from the $0.2-\mathrm{Ma}$ volcanics of the Phlegraean fields immediately northwest of Vesuvius.

\section{Volcaniclastic Sediments Sites 656 and $655,654,653,652$}

These sites do not contain numerous volcaniclastic layers, and those present are thin, on the order of centimeters, with the thickest a 1-m layer at Hole 653B. The paucity of tephra reflects the position of these sites out of dominant eolian transport paths from major volcanic fields, and away from significant turbidite input such as on seamounts. Only two volcaniclastic layers were recovered at Site 656 , one at Site 655 , and none at Site 654

At Site 655, on the flanks of the Gortani Ridge (Figs. 1, 2), volcaniclastic layers occur within the Plio-Pleistocene succession; normal grading and rare parallel lamination suggest deposition as turbidities. Glass chemistry here, as well as for vitrics at Site 653 , shows both rhyolitic and trachytic composition, suggesting a volcanic provenance on peninsular Italy (Pontine area). The uniform glass chemistry of each layer is indicative of deposition from a single volcanic event followed by reworking.

At Holes 656A and 656B, located on the westward flank of the De Marchi seamount (Figs. 1, 2), the Plio-Pleistocene succession (below an upper washed interval) contains a subordinate detrital and volcanogenic component. In Hole 656A, the upper Pleistocene interval includes a 5-cm-thick sand, rich in zeolites. In both Holes 656A and -B, the middle and lower Pleistocene successions include minor volcanic glass and several thin intervals of zeolite-bearing sandy mud. Slumping occurred during, and after, late Pliocene time.

Seismic stratigraphic evidence (Kastens, Mascle, et al., 1987) indicates Sites 655 and 656, both located on the lower Sardinian 


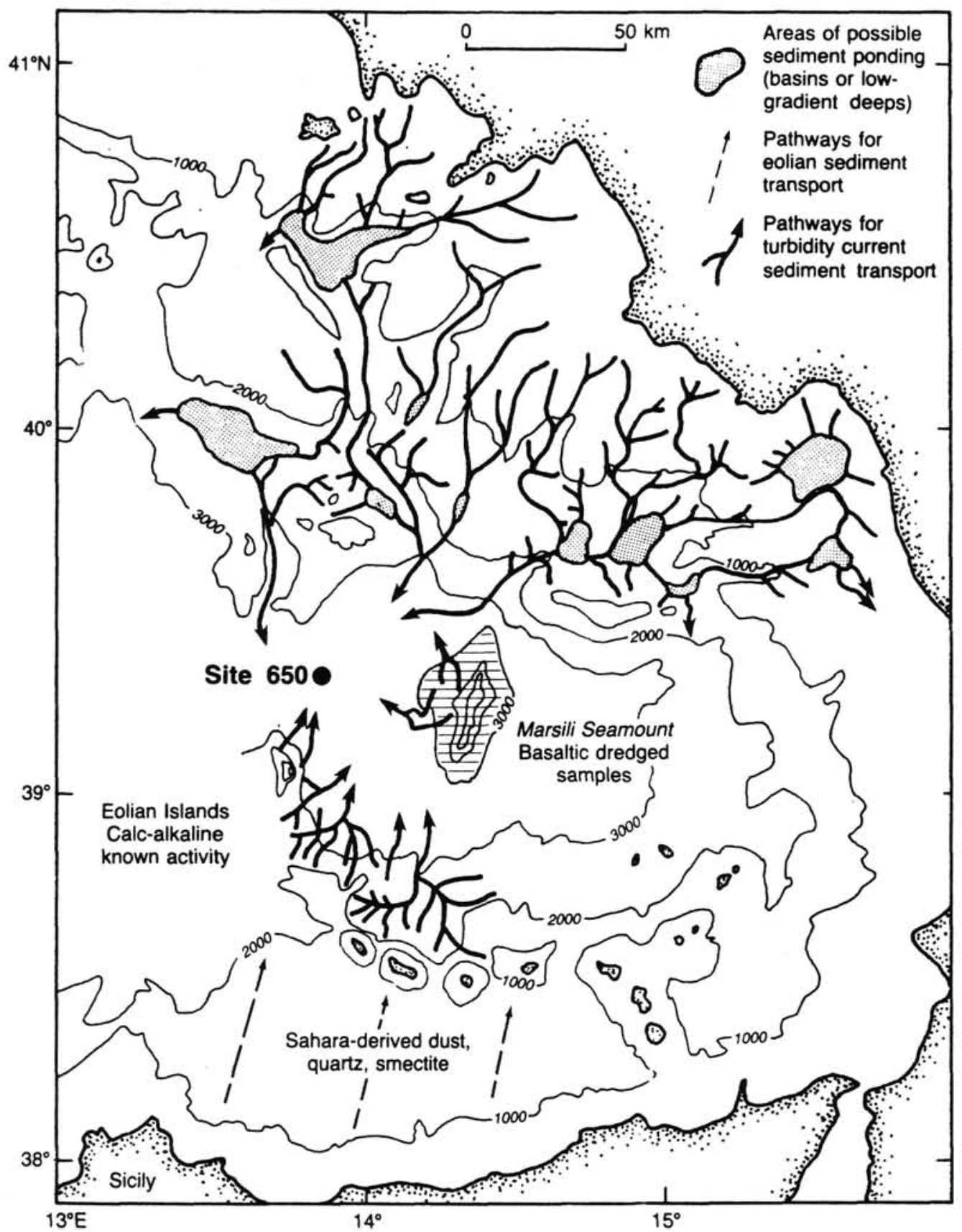

Figure 16. Sketch map of the Marsili Basin illustrating modern and inferred Pleistocene input pathways of volcaniclastic and terrigenous sediment.

margin, were topographically isolated from gravity input of clastic sediment from adjacent land areas. Local gravitational sediment reworking characterizes the successions cored on the flank of the De Marchi seamount (Holes 656A and -B). Mineral grains such as zircon, pyroxene, and blue amphibole, indicate erosion from the local continental basement of De Marchi seamount. Appropriate source rocks were cored in the Messinian interval at this site (see earlier). The De Marchi seamount apparently remained largely free of sediment during Pliocene time and continued to shed lithoclastic sediment into an otherwise pelagic and/or hemipelagic succession. Slumping may relate to instability and subsidence related to ocean crust genesis in the adjacent Vavilov Basin.

At Site 655 , on the basaltic Gortani Ridge, the heavy mineral-rich sand probably relates to current reworking (if not a drilling artifact). Thin debris flows just above the basaltic basement indicate minor gravitational sediment instability. Also, nannofossil ooze clasts were derived from successions of contrasting ages (Shipboard Scientific Party, 1987e), indicating reworking by currents and/or gravity.

Much of the volcanic ash was transformed to zeolite with diagenesis. Two zeolite-rich layers, and another layer with fresh vitrics, occur in the Messinian of Site 654.

\section{Leg 107 Organic-rich Sediments and Sapropels}

Widespread, thin sapropelic layers and sapropels were sampled during Leg 107. (Sapropels have more than 2\% organic carbon; sapropelic layers have $0.5 \%-2 \%$ organic carbon; Kidd et al., 1978; see also Cita et al., 1973, 1982; Cita and Grignani, 1982.) Prior to Leg 107, such organic-rich sediments in the Tyr- 
rhenian were recorded only in a piston core by the Swedish Deep Sea Expedition (Olausson, 1961) and as a single lump of organic-rich marl at Site 373 in the Vavilov Basin (Core 1, Section 2). During Leg 107, at least 61 sapropels and sapropelic layers were identified, based on measured organic carbon content. Most accumulated during the late Pliocene to middle Pleistocene (Sites 651, 652) or during the period 1.3-0.6 Ma (Sites 650, 651 , and 652, Hole 653B, and Sites 654 and 655); preservation may correlate with moderately higher sedimentation rates that quickly bury but do not dilute, rework, or oxidize organic-rich material.

Sapropels and sapropelic layers of late Pliocene to middle Pleistocene were recovered most extensively at Site 652 on the lower Sardinian slope (Figs. 1, 2). A total of eight sapropel layers were identified aboard ship, based on color, fine lamination, petroliferous odor, and carbon content. Post-cruise studies have identified additional black, possibly organic-rich layers in the Marsili Basin (Site 650; 17 layers, 6 possibly sapropels) and the Vavilov Basins (Site $651 ; 21$ layers, 13 possibly sapropels) in the NN20-NN19 nannofossil intervals.

Six sapropels and two sapropelic layers of upper Pliocene to middle Pleistocene age were sampled on the lower Sardinian margin, at Site 652 (Fig. 8). The best developed of these sapropels $(652 \mathrm{~A}-6 \mathrm{R}-1,30-60 \mathrm{~cm})$ is a gray to a finely-laminated black mud with a maximum of $4.18 \%$ organic carbon (Shipboard Scientific Party, 1987b). The upper boundary contains small-scale Chondrites-type burrowing.

Sapropels and sapropelic layers also occur in the Pleistocene section on the lower Sardinian slope, at Holes 653A and 653B. On the Gortani Ridge, at Site 655 six sapropels and/or sapropelic layers were recognized in the Pleistocene succession that contain up to $\mathrm{C}_{\text {org }}=5.3 \%$ (Shipboard Scientific Party, 1987e). Here sapropels occur in a typical succession of normal-burrowed foram-nannofossil oozes with increased iron-monosulfide specks upward, passing into olive-gray foraminiferal marls, then into black finely-laminated sapropels without foraminifera. Bioturbation gradually increases upward and the color becomes paler within the sapropel until finally passing back into typical foramnannofossil oozes.

Organic-rich layers were also encountered in the Pleistocene section of the upper Sardinian margin at Site 654 as several grayish layers (two are sapropelic layers and one is a true sapropel). By contrast, organic-rich layers were not recorded at Site 656 , on the flanks of the De Marchi seamount, possibly reflecting hiatuses in the lower Pliocene and lower Pleistocene (Shipboard Scientific Party, 1987f).

The possible origin of the Western Mediterranean organicrich sediments is discussed elsewhere in this volume in papers by Mukhopadhyay et al. and McKenzie et al. However, in general the Leg 107 organic-rich sediment discoveries indicate much more widely developed sediment anoxia throughout the Mediterranean than previously envisaged. The Leg 107 sapropels are possibly most effectively interpreted using a modification of the existing barred basin-density stratification model (Nesteroff, 1973; Kidd et al., 1978). During warm interglacial times, melt waters flooded into the Mediterranean from the Black Sea basin. Distinctive low salinity nannofossil floras flourished. Low salinity waters flowed into the Atlantic, and estuarine circulation halted. The Straits of Gibraltar at $\sim 550 \mathrm{~m}$ barred influx of Atlantic deep water. A salinity stratification was established throughout much or all of the Mediterranean. Organic-rich sediments accumulated in stagnant anoxic deep water. However, the local basin configuration and nature and rate of background sedimentation also greatly influenced the development of individual organic-rich layers. As the glacial meltwater influx waned and evaporation increased, "estuarine" conditions were re-es- tablished and the Mediterranean returned to being well-mixed, with oxic sedimentation.

\section{Climate-controlled Cyclicity in Sedimentation}

In the Tyrrhenian Sea clastic sediment accumulation, or abundance, is fundamentally controlled by concentration within topographic basins or "sinks." Pleistocene sea-level fluctuations directly influenced clastic sediment input into the sink. During sea-level highstands, clastic sediment was preferentially retained on the shelf, while low sea-level stands favored erosion and reworking of shelf sedimentation into the basin (e.g., Vail et al., 1977).

The relative abundance of clastic layers, primarily emplaced by turbidity currents and other gravitationally-driven mass flows, correlates with glacial cycles. Paleomagnetic studies (Channell and Torii, this volume), isotopic studies (Thunell, 1979), clay mineral studies (Chamley and Visser, this volume), and biostratigraphical studies (Cita, 1973; Cita et al., 1973) all substantiate this correlation: low magnetic susceptibility corresponds to low concentrations of magnetic minerals during eustatic sea-level highs when pelagic carbonate predominated over clastic input. The relative abundances of mixed-layer clay and smectite show correlation with glacial/interglacial cycles, assuming these clays were mainly reworked from terrestrial volcanic sources, or via temporary continental shelf sinks, during sea-level lowstands.

Thus, large volumes of fluvially-derived clastic sediment were trapped inshore and in shelf basins during interglacials, when subaerial erosion and run-off was extensive (Perityrrhenian basin; Selli, 1974). As sea level fell, shelf areas were exposed and clastic sediments reworked, then redeposited, via an extensive submarine canyon system into the basin depocenters (Fig. 16).

\section{Plio-Pleistocene Seafloor Instability}

During Pliocene and Pleistocene time, the focus of tectonic instability shifted from the Sardinian margin to the southeastern Tyrrhenian Sea, associated with crustal genesis and back-arc basin evolution. Consequently, Plio-Pleistocene sedimentary successions recovered from the Sardinian margin at Site 652 and 654 show little tectonic disturbance except locally, especially on structural highs (Site 656). Near the toe of the Sardinian margin Plio-Pleistocene sediments at Holes $653 \mathrm{~A}$ and $-\mathrm{B}$ contain a 5$\mathrm{cm}$-thick debris flow composed of deformed, multicolored nannofossil ooze and mud clasts in a mud and clay matrix. Slightly lower in the succession in Hole 653B, inversion of biostratigraphic sequences with nannofossil muds of middle to late Pliocene age (NN16-NN20), occurring above younger Pliocene sediment (see Shipboard Scientific Party, 1987f), suggests that large scale slump-folds may be present. There is also evidence of slumping on the flanks of the De Marchi seamount (Holes $656 \mathrm{~A},-\mathrm{B})$ during Pliocene time. On the crest of the Gortani Ridge (Fig. 1) several debris flows were recorded. Pebbles within these debris flows contain microfossils of varied age; a small normal fault was also noted within one of the debris-flow intervals.

More intense tectonic instability was recorded in the Vavilov and Marsili Basins. Dipping strata, slumps, convolute lamination and faulting indicate post-depositional tectonic effects. At Site 650, in the Marsili Basin (Fig. 1) small-scale slumps, synsedimentary folds, and zones of convolute lamination are common in both the Pliocene and the Pleistocene intervals. At least some of the many faults are associated with a slight change in dip and appear not to be drilling artifacts. Syn-sedimentary features in the Vavilov Basin at Site 651 first appear in the basal 40 $\mathrm{m}$ of the Pliocene succession. Apparent dips of lamination are variable up to $45^{\circ}$. Mud flows and resedimented soft pebbles 
also occur within fine-grained sediments, together with a neptunian dike, $10 \mathrm{~cm}$ long $\times 2.5 \mathrm{~cm}$ wide.

\section{Tectonic Controls on Sedimentation}

Following Messinian rifting and subsidence, the Sardinian margin was relatively stable, subsiding gently during Plio-Pleistocene time. Sediment slumped on the flanks of the De Marchi seamount and the Gortani Ridge (Site 655). Slumped sediment at Holes $653 \mathrm{~A}$ and -B, near the base of the Sardinian margin, was derived from local basement highs, for example the Secchi Seamount and/or the Monte della Rondine to the south.

At Site 651 in the Vavilov Basin, marked apparent dip resulted from tilting of the underlying oceanic basement, during and/or following, accumulation of the basal $\sim 40 \mathrm{~m}$ of the succession. Earthquakes possibly triggered dewatering and the formation of neptunian dikes. The basement tilting was, however, too small in scale to be recorded in seismic data (Shipboard Scientific Party, 1987a). In the Marsili Basin (Site 650), slumping and possible microfaulting may be related in some complex way to the effects of sediment loading, basement subsidence, volcano-tectonic effects, and/or Eolian arc magmatism. Taken together, the inferred formation age and the high vesicularity suggest that the igneous basement erupted in water shallower than $2,500 \mathrm{~m}$ and subsided at $700 \mathrm{~m} / \mathrm{Ma}$, three times faster than normal oceanic crust formed at mid-ocean ridges (Kastens, Mascle, et al., 1987).

\section{DISCUSSION AND CONCLUSIONS}

\section{Tectonic Setting of Tyrrhenian Basin Sedimentation}

In outline, the plate tectonic setting of Tyrrhenian Sea sedimentation evolved as follows:

During late Triassic time, the northern margin of Gondwanaland rifted and progressively disintegrated, giving rise, during Jurassic and Cretaceous time, to a number of small ocean basins and microcontinents sited between the African and Eurasian supercontinents (Smith, 1971; Dewey et al., 1973; BijuDuval et al., 1977; Sengör and Yilmaz, 1981; Robertson and Dixon, 1984; Dercourt et al., 1986). Some areas of Mesozoic ocean were already closing by Late Jurassic time (e.g., in the Hellenides and Dinarides) and this process accelerated in the Late Cretaceous (e.g., Taurides, Astroalpine system).

The relative positions of Africa and Eurasia, as deduced from paleomagnetic and marine magnetic data, indicate that substantial oceanic tracts persisted into Tertiary time (Livermore and Smith, 1985). Mainly northward subduction of Mesozoic oceanic crust was associated with crustal extension and rifting along north Tethyan margins. In the western Mediterranean area, Late Cretaceous and Paleogene northward subduction of Mesozoic oceanic crust resulted in the Corsica-Sardinia and Calabria blocks rifting from southeastern Europe with the development of new oceanic crust in the Balearic basin (Boccaletti and Guazzone, 1972; Hsü, Mondadert et al., 1978; Chanell et al., 1979). With continued consumption of Mesozoic oceanic crust, the Corsica-Sardinia block was eventually juxtaposed with the Apennine area by early Miocene time. The Northern Apennines can be considered a fold and thrust belt developed as a type of accretionary prism during attempted subduction of the old Mesozoic continental margin of the Adria (Treves, 1984).

By the late Miocene, the only remaining Mesozoic oceanic crust was located in the Ionian Sea (Morelli, 1985; Finetti, 1985; Granjacquet and Mascle, 1978). Northwestward subduction of oceanic crust between the Apennine, and the North African (Sicily) continental block then resulted in rifting and formation of the deep late Miocene Tyrrhenian basins (Rehault et al., 1987). By the Pliocene and Pleistocene, the Apennines were rotated counterclockwise, bending the Calabrian arc (Scandone,
1979; Channell, 1986; Moussat, 1983; Moussat et al., 1985); arc volcanism was active in the Eolian Islands (Beccaluva et al., 1981, 1982; Keller et al., 1978), and new oceanic-type crust formed in the Marsili and Vavilov Basins.

\section{Implications of Leg 107 Tyrrhenian Sea Sediments}

The sedimentary evidence from Leg 107 confirms that the Tyrrhenian Sea developed in two stages; rifting of Calabria from Sardinia during late Miocene-Tortonian and Messinian time, followed by final break-up to the southeast in the Pliocene and Pleistocene, as new oceanic crustal basins were created.

During Tortonian (or earlier) rifting, clastic sediments were derived from rotated fault-blocks composed of Hercynian basement and Mesozoic cover rocks, similar to exposures in Sardinia (Site 654). By Messinian time, provenance was also from localized fault-blocks of metamorphosed ophiolitic rocks (Holes $656 \mathrm{~A},-\mathrm{B})$ of Ligurian and Piedmontese type, as exposed in Corsica. During Messinian, the lower Sardinian margin area remained attached to Italy, as shown by derivation of coarse siliciclastic sediments (Site 652) from a terrane similar to the Mesozoic low-grade metamorphic and Tertiary cover units of the southern Apennines and/or the Maghrebid units of North Africa. By the time of the Messinian desiccation event, a deep water basin $(\geq 1000 \mathrm{~m}$ ) already existed in the present upper Sardinian margin area (Site 654), while sites now in the lower Sardinian margin were apparently higher standing and still continental. Tilting and subsidence apparently occurred more than a million years earlier on the upper margin than on the lower margin. This diachroneity is explained in terms of either "roll back" of the rift axis above a southeastward migrating subduction zone, or, alternatively, by the geometry of shear and detachment within rifting continental crust (Kastens, Mascle, et al., 1987).

To this developing "rift-drift" scenario was superimposed the Messinian salinity crisis. Influence of extensive tectonics on evaporitic paleoenvironments is highlighted by Leg 107 . During late Tortonian-early Messinian time, the sea level began to fall, with the creation of a fertile, silled basin in which anoxic, siliceous sediments accumulated (Site 654). Sea-level fall in the Messinian created a series of evaporitic sub-environments. In the existing basin (Site 654) on the upper Sardinian margin, finely-laminated balatino-type gypsum precipitated cyclically during times of hypersalinity, punctuated by marine influxes. Elsewhere on the lower Sardinian margin (Site 652), Messinian sediments accumulated on a more elevated closed inward-draining lake of variable salinity. Tectonic controls on sedimentation include a possible alluvial fan progradation event, and extensive reworking of gypsum (Site 652). Coarse-grained terrestrial breccia was shed locally from a local tilting fault block on the lower Sardinian margin (Holes 656A, -B). Sulfur- and limonite-rich oxide sediments on the lower Sardinian margin (Holes 653A, -B) were precipitated from springs, possibly located near the shores of a saline lake.

By the end of Messinian time, the seas were flooding back. Strongly oxidized, subaerially weathered sediment and iron oxide were reworked by the advancing seas giving rise to distinctive reddish and/or multicolored silts and muds (Holes 653A, -B; Site 652), oozes (Site 654), and sands (Site 653) at the base of the Pliocene succession.

By early Pliocene the eastern margin of the earlier subsided rift zone (Site 654) was deeply submerged and overlain by nannofossil ooze and marl (Site 652) related to final continental separation to the southeast and genesis of oceanic-type lithosphere in the Marsili and Vavilov Basins. In the Plio-Quaternary, the whole Tyrrhenian Sea was effectively a single basin undergoing background pelagic carbonate accumulation, influenced by tectonic and volcanic effects, and regional and global climatic change. 
Oceanic lithosphere was formed beneath already pelagic carbonate-depositing seas, associated with faulting and breccia formation (Site 651). Ultramafic rocks were protruded to the seafloor near the axis of the Vavilov Basin (Bonatti et al., this volume). Tilting continued after accumulation of the overlying basal sediments, with water-escape (neptunian dike), fault, and slump structures. Following deposition, the basal Fe-Mn rich carbonate sediments were dolomitized by low-moderate-temperature hydrothermal processes (Site 651).

During Pliocene and Pleistocene, volcanic-derived sediment was introduced from the Italian mainland and the Eolian Islands, mainly by turbidity currents and debris-flow. $\mathrm{U}$ and $\mathrm{Th}$ ratios determined by well-logging (Site 651) suggest provenance from the potassic volcanic province north of Rome. Abundant volcaniclastic sediment in the Vavilov Basin appears in the late Pliocene. Calc-alkaline and shoshonitic sediment compositions suggest derivation from the Eolian Islands to the southeast. Airfall tuff is very subordinate relative to reworked volcaniclastic sediment generally. Even where tuffs accumulated on a basement high, for example, the Gortani Ridge (Site 655), reworking has taken place. Ash was commonly diagenetically altered to zeolite, especially overlying the oceanic-type basement where heatflow was highest.

Pleistocene sediment deposition was influenced by eustatic sea-level change; the abundance of turbidities, mostly volcaniclastic, generally correlates with the relative abundance of mixedlayer clays and smectites and with intervals of high magnetic susceptibility. Smectites were eroded from land volcanic exposures. During sea-level highstands, sediment was trapped in "peri-tyrrhenian" shelf basins and was later reworked into the deep basin by gravity processes during glacial periods when sea level fell.

Africa-Eurasian convergence has continued actively in the western Mediterranean, as indicated by the Benioff zone dipping beneath the southeastern Tyrrhenian Sea and continued volcanism in the Eolian Islands (Rehault et al., 1987). However, subduction in this area now may well be drawing to a close. In the future any remaining Ionian Sea oceanic transitional crust presumably will be consumed until collision with the North African continental margin. The southeast Tyrrhenian Sea igneous crust and its sedimentary cover could then well be obducted as an ophiolitic nappe, comparable to other older examples emplaced by the Alpine-Mediterranean orogenic belt.

\section{ACKNOWLEDGMENTS}

This summary and synthesis draws on all the sedimentological and other relevant data collected by the Shipboard Scientific Party. The efficient and friendly help of the Shipboard Scientific Technical Staff contributed tremendously. Very helpful comments on the draft manuscript were received from $\mathrm{K}$. Kastens and anonymous referees.

\section{REFERENCES}

Auboin, J., Bonneau, M., Celet, P., Charvet, J., Clement, B., Degardin, J. M., Dercourt, J., Ferrière, J., Fleury, J. J., Guernet, C., Maillot, H., Mania, J. H., Mansy, J. L., Terry, J., Thiebault, P., Tsoflias, P, and Verriex, J. J., 1970. Contributions a la géologie des Héllenides: le Gavrovo, le Pinde et la zone ophiolitque subpelagonienne. Ann. Soc. Géol. Nord, 90:277-306.

Ballard, R. D., and Moore, J. G., 1977. Photographic atlas of the MidAtlantic Ridge rift valley. New York (Springer-Verlag), 1-114.

Barberi, F., Bizouard, H., Capaldi, B., Ferrara, G., Gasparini, P., Innocenti, F., Joron, J. L., Lambert, B., Treuil, M., Allegre, C., 1978. Age and nature of basalts from the Tyrrhenian abyssal plain. In Hsü, K. J., Montadert, L., et al., Init. Repts. DSDP, 42 (Pt. 1): Washington (U.S. Govt. Printing Office), 509-514.

Barberi, F., Innocenti. F., Ferrara, G., Keller, J., and Villari, L., 1974. Evolution of Eolian arc volcanisms (southern Tyrrhenian Sea) Earth. Planet. Sci. Lett., 21:269-276.
Barone, A., Fabbri, A., Rossi, S, and Sartori, R., 1982. Geological structure and evolution of the marine areas adjacent to the Calabrian Arc. Earth Evol., 3:207-221.

Barrett, T. J., and Spooner, E.T.C., 1977. Ophiolitic breccias associated with allochthonous oceanic crustal rocks in the east Ligurian Apennines, Italy - a comparison with observations from rifted ocean ridges. Earth. Planet. Sci. Lett., 35:79-91.

Beccaluva, L., Gabbianelli, G., Lucchini, F., Rossi, P. L., and Savelli, C. 1985. Petrology and K/Ar ages of volcanics dredged from the Eolian seamounts: implications for geodynamic evolution of the southern Tyrrhenian basin: Earth and Planetary Science Letters, 74:187208.

Beccaluva, L., Gabbianelli, G., Lucchini, P., Rossi, P. L., Savelli, C., and Zeda, O. 1981. Magmatic character and K/Ar ages of volcanics dredged from the Eolian seamounts (Tyrrhenian Sea). In Wezel, F. C. (Ed.) Sedimentary basins of Mediterranean margins C.N.R. Italian Project of Oceanography, Tecnoprint Bologna, 361-368.

Beccaluva, L., Rossi, P. L., and Serri, B., 1982. Neogene to Recent volcanisms of the southern Tyrrhenian-Sicilian area: implications for the geodynamic evolution of the Calabrian arc. Earth Evol. Sci., 3: 222-238.

Bell, D. L., and Goodel, H. G. 1967. A comparative study of glauconite and the associated clay fraction in modern marine sediments. Sedimentology, 9:169-202.

Bernoulli, D., Garrison, R. E., and McKenzie, J. 1978. Petrology, isotope chemistry, and origin of dolomite and limestone, associated with basaltic breccia, Hole 373A, Tyrrhenian basin. In Hsü, K. J., Mondadert, L., et al., 1978. Init. Repts. DSDP, 42 (Pt. 1), Washington, (U.S. Govt. Printing Office), 541-558.

Biju-Duval, B., Dercourt, J., and Le Pichon, X., 1977. From the Tethys ocean to the Mediterranean seas: a plate tectonic model of the evolution of the Western Alpine system. In Biju-Duval, B., and Montadert, L. (Eds.) Structural history of the Mediterranean basins. Paris (Editions Technip.), 143-164.

Boccaletti, M., and Guazzone, G., 1972. Remnant ares and marginal basins in the Cainozoic development of the Mediterranean. Nature, 252:18-21.

Boillot, G., Grimaud, S.. Mauffret, A., Mougenot, D., Mergoil-Daniel, J., Kornprobst, J., and Torrent, G., 1980. Ocean-continent boundary off the Iberian margin: a serpentinite diapir west of the Galicia Bank. Earth. Planet. Sci. Lett., 48:23-34.

Bonatti, E., Emiliani, C., Ferrara, G., Honnorez, J., and Rydell, H., 1974. Ultramafic carbonate breccias from the equatorial Mid-Atlantic Ridge. Mar. Geol., 16:83-102.

Bosellini, A., and Rossi, D., 1974. Triassic carbonate build-ups in the Dolomites, northern Italy, Spec. Publ. Soc. Econ. Paleontol. Mineral. 18:209-233.

Channell, J.E.T., 1986. Palaeomagnetism and continental collision in the Alpine Belt and the formation of late-tectonic extensional basins. In Coward, M. P., and Ries, A. C. (Eds.) Collision Tectonics Geol. Soc. Spec. Publ., 19:261-286.

Channell, J.E.T., D'Argenio, B., and Horuth, F., 1979. Adria, the African Promontory in Mesozoic Mediterranean palaeogeography. Earth Sci. Rev., 15:213-292.

Cita, M. B. 1973. Pliocene biostratigraphy and chronostratigraphy. In Ryan, W.B.F., Hsü, K. J., et al., Init. Repts. DSDP, 13: Washington (U.S. Govt. Printing Office), 1343-1379.

Cita, M. B., and Grignani, D. 1982. Nature and origin of late Neogene Mediterranean Sapropels. In Schlanger, S. W., and Cita, M. B. (Eds.). Nature and Origin of Cretaceous Carbon-rich Facies: London (Academic Press), 165-196.

Cita, M. B., Chierichi, M. A., Cliampo, G., Moncharmont, Z. M., d'Onofrio, S., Ryan, W.B.F., and Scorziello, R., 1973. The Quaternary record of the Tyrrhenian and Ionian Basins of the Mediterranean Sea. In Ryan, W.B.F., Hsü, K. J., et al. Init. Repts. DSDP., 13, Washington (U.S. Govt. Printing Office), 1263-1341.

Cita, M. B., Wright, R. C., Ryan, W.B.F., and Longinelli, A., 1978. Messinian paleoenvironments. In Hsü, K. J., Montadert, L., et al., Init. Repts. DSDP, 42 (Pt. 1): Washington (U.S. Government Printing Office), 1003-1035.

Colantoni, P., Fabbri, A., Gallignani, P., Sartori, R., and Rehault, J.P., 1981. Carta lithologica e stratigraphica del Mari Italiano. Coniglio Nazionale Richerche, Publ. 4. 
Cortesogno, L., Galbiati, B., Principi, G., and Venturelli, G., 1978. Le brecce ofiolitiche della Liguria orientale: nuovi dati; modeli paleogeografici, Ofioliti, 3:99-160.

Curray, J. R., Moore, D. G., et al. 1982. Init. Repts. DSDP. 64, Washington (U.S. Govt. Printing Office).

Decima, A., and Wezel, F. C., 1973. Late Miocene evaporites of the central Sicilian Basin. In Ryan, W.B.F., and Hsü, K. J., et al:: Init. Repts. DSDP. 13, Washington (U.S. Govt. Printing Office), 12341240.

Dercourt, J., Zonenshain, L. P., Ricou, L. E., Kazmin, V. G., LePichon, X., Knipper, A. L., Grandjacquet, C., Sbortshikov, I. M., Geyssant, J., Lepvrier, C., Pechersky, D. H., Boulin, J., Sibuet, J. C., Savostin, L. A., Sorokhtin, O., Westphal, M., Bazhenov, M. L., Laver, J. P., and Biju-Duval, B., 1986. Geological evolution of the Tethys Belt from the Atlantic to the Pamirs since the Lias: Tectonophysics, 123:241-315.

Dewey, J. F., Pitman, W. C., III, Ryan, W.B.F., and Bonnin, J., 1973. Plate tectonics and the evolution of the Alpine system. Bull. Geol. Soc. Am., 84:3137-3180.

Dumont, J. F., Gutnic, M., Marcoux, J., Monod, O., and Poisson, A., 1972. Le Trias des taurides occidentales (Turquie), definition du bassin pamphylien: Un noveau domaine à ophiolites à la marge externe de la chaine taurique, Zeit. Deutsch. Geol. Ges., 123:385-409.

Fabbri, A., and Curzi, P., 1979. The Messinian of the Tyrrhenian Sea: seismic evidence and dynamic implications. G. Geol., 43;215-248.

Fabbri, A., Gallignani, P., and Zitellini, N., 1981. Geologic evolution of the peri-Tyrrhenian sedimentary basins. In Wezel, F.,C. (Ed.), Sedimentary Basins of Mediterranean Margins. Bologna (Technoprint), 101-126.

Finetti, I., 1985. Structure and evolution of the Central Mediterranean (Pelagian and Ionian Seas). In Stanley, D. J., and Wezel, F. C. (Eds.) Geological evolution of the Mediterranean basin. New York (Springer Verlag), 215-230.

Finetti, I., Morelli, C., and Zarudzki, E., 1970. Reflection seismic study of the Tyrrhenian Sea. Boll. Geofis. Teor. Appl., 12:311-346.

Garrison, R. E., 1972. Inter- and intra-pillow limestones of the Olympic Peninsula, Washington, J. Geol., 80:4310-4322.

Garrison, R. E., Schreiber, B. C., Bernoulli, D., Fabricius, F., Kidd, R. B., and Melieres, F., 1978. Sedimentary petrology and structures of Messinian evaporitic sediments in the Mediterranean Sea. Leg 42A. Deep Sea Drilling Project, In Hsü, K. J., and Montadert, L., et al., Init. Repts. DSDP, 42 (Pt. 1), Washington (U.S. Govt. Printing Office), 571-612.

Gennesseaux, M., Rehault, J-P., Thomas, B., Colantoni, P., Fabbri, A., Lepvrier, C., Mascle, G., Mauffret, A., Polino, R., Robin, C., and Vanney, J., 1986. Resultats des plongees en submersible Cyana sur les blocs continentaux bascules (mer Tyrrhenienne centrale). C. $R$. Acad. Sci. (Paris), 302:785-792.

Glennie, K. W., Boeuf, M.G.A., Hughes-Clarke, M. W., Moody-Stuart, M., Pilaar, W.F.H., and Reinhardt, B. M., 1973. Late Cretaceous nappes in the Oman Mountains and their geological evolution. Bull. AAPG, 57:5-27.

Grandjacquet, C., and Mascle, G., 1978. The structure of the Ionian Sea, Sicily and Calabria-Lucania, In Nairn, A.E.M., et al. (Eds.), The Ocean Basins and Margins (Vol. 4B); New York (Plenum Press), 257-329.

Hardie, L. A., 1967. The Gypsum-anhydrite equilibrium at one atmosphere pressure. Am. Mineral., 52:171-200.

Hardie, L. A., Smoot, J. P., and Eugster, H. P., 1978. Saline lakes and their deposits: a sedimentological approach. In Matter, A., and Tucker, M. E. (Eds.), Modern and Ancient Lake Sediments, Spec. Publ. Int. Ass. Sediment., 2:7-41.

Heezen, B. C., Gray, C., Segre, A. G., and Zarudski, E.F.K., 1971. Evidence of foundered continental crust beneath the central Tyrrhenian Sea. Nature, 229:327-329.

Hsü, K. J., and Cita, M. B. 1973. The origin of the Mediterranean evaporites. In Ryan, W.B.F., and Hsü, K. J., et al.: Init. Repts. DSDP, 13, Washington (U.S. Govt. Printing Office), 1203-1231.

Hsü, K. J., Montadert, L., et al., 1978. Init. Repts. DSDP, 42, Pt. 1: Washington (U.S. Govt. Printing Office).

Hsü, K. J., Montadert, L., Bernoulli, D., Cita, M. B., Erickson, A., Garrison, R. E., Kidd, R. B., Melieres, F., Müller, C., and Wright, R., 1978. History of the Mediterranean salinity crisis. In Hsü, K. J., Montadert, L., et al., 1978. Init. Repts. DSDP, 42, (Pt. 1): Washington (U.S. Govt. Printing Office). Init. Repts. DSDP, 1053-1078.
Kastens, K. A., Mascle, J.,et al., 1987. Proc. ODP, Init. Repts., 107: College Station, TX (Ocean Drilling Program).

Keller, J., Ryan, W.B.F., Ninkovitch, D., and Altherr, R., 1978. Explosive volcanic activity in the Mediterranean over the past 200,000 years as recorded in deep sea sediments. Geol. Soc. Am. Bull., 89: 591-604.

Kidd, R. B., Cita, M. B., and Ryan, W.B.F., 1978. Stratigraphy of Eastern Mediterranean sapropel sequences recovered during Leg $42 \mathrm{~A}$ and their paleoenvironmental significance.In Hsü, K. J., Montadert, L., et al., 1978. Init. Repts. DSDP, 42, (Pt. 1): Washington (U.S. Govt. Printing Office), 421-443.

Laubscher, H-P., and Bernoulli, O. 1977. Mediterranean and Tethys. In Nairn, A.E.M., Kanes, W. H., Stehli, F. G. (Eds.), The ocean basins and margins. 4A, The Eastern Mediterranean, New York (Plenum), $1-28$.

Leeder, M. R., and Gawthorpe, R. L., 1987. Sedimentary models for extensional basins. In Coward, M. P., Dewey, J. F., and Hancock, P. L. (Eds.), Continental extensional tectonics. Spec. Publ. Geol. Soc. Lond., 28:139-152.

Lemoine, M., 1980. Serpentinites, gabbros and ophicalcites in the Piemont-Ligurian domain of the Western Alps: Possible indicators of oceanic fracture zones and of associated serpentinite protrusions in the Jurassic-Cretaceous Tethys. Arch. Sci. Genève, 33:103-115.

Livermore, R. A., and Smith, A. G., 1985. Some boundary conditions for the evolution of the Mediterranean region. In Stanley, D. J. and Wezel, F. C., (Eds.) Geological evolution of the Mediterranean ba$\sin$. New York (Springer Verlag), 83-100.

Malinverno, A., 1981. Quantitative estimates of age and Messinian paleobathymetry of the Tyrrhenian Sea after seismic reflection, heat flow and geophysical models. Boll. Geofis. Teor. Appl., 23:159-171.

Malinverno, A., Cafiero, M., Ryan, W.B.F., and Cita, M. B., 1981. Distribution of Messinian sediments and erosional surfaces beneath the Tyrrhenian Sea: geodynamic implications. Oceanol. Acta, 4: 489-496.

Malinverno, A., and Ryan, W., 1986. Extension in the Tyrrhenian Sea and shortening in the Apennines as result of arc migration driven by sinking of the lithosphere. Tectonics, 5:227-245.

McKenzie, J. A., Hsü, K. J., and Schneider, J. F., 1980. Movement of subsurface waters under the sabkha, Abu Dhabi, UAE, and its relation to evaporite dolomite genesis. In Zenger, D. H., Dunham, J. B., and Ethington, R. L. (Eds.), Concepts and Models of Dolomitization. Soc. Econ. Paleontol. Miner. Spec. Publ., 28;11-30.

McKenzie, J. A., Jenkins, H. C., and Bennet, G. G., 1979. Stable isotopic study of the cyclic diatomite-claystone from the Tripoli Formation, Sicily: A prelude to the Messinian salinity crisis. Paleogeogr. Paleoclimatol., Paleoecol., 29:125-142.

McRae, S. G., 1972. Glauconite. Earth Sci. Rev., 8:397-440.

Mitchell, A.H.G., and Reading, H. G., 1986. Sedimentation and tectonics. In Reading, H. G. (Ed.) Sedimentary environments and facies. Oxford (Blackwell Scientific Publ.), 471-512.

Morelli, C., 1985. Geophysical contributions to knowledge of the Mediterranean crust. In Stanley, D-J., and Wezel, F. C. (Eds.) Geological evolution of the Mediterranean basin. New York (Springer Verlag), 65-82.

Moussat, E., 1983. Evolution de la Mer Tyrrhenienne centrale et orientale et de ses marges septentrionales en relation avec la neotectonique dans l'Arc Calabrais. [Thèse] Université P. et M. Curie, Paris,

Moussat, E., Mascle, G., and Angelier, J., 1985. Regimes de paleocontraintes et deformation de l'arc tyrrhenian. C.R. Acad. Sci., Paris, 300:417-422.

Nesteroff, W. D., 1973. Distribution of fine-grained sediment component in the Mediterranean. In Ryan, W.B.F., and Hsü, K. J. et al. Init. Repts. DSDP, 13, Washington (U.S. Govt. Printing Office), 666-669.

Nesteroff, W. D., Wezel, F. C., and Pautot, G., 1976. Summary of Lithostratigraphic finding and problems. In Ryan, W.B.F., and Hsü, K. J., et al., 1973. Init. Repts. DSDP. 13, Washington (U.S. Govt. Printing Office), 1021-1043.

Odin, G. S., and Matter, A., 1981. De glauconarium origien. Sedimentology, 28:611-641

Ogniben, L., 1957. Petrografia della Serie Solfifera Siciliana e considerazioni geologische relative, Marie Descrittive della Carta Geologica d'Italia 33.

Ohnenstetter, M., 1979. Contribution a l'étude des ophiolites du domaine méditerranean. [Thèse] Science Univ., Nancy. 
Olausson, E., 1961. Studies in deep-sea cores. Repts. Swed. Deep-Sea Exped., 1947-48, 8:337-391.

Pearce, J. A., Lippard, S. J., and Roberts, S. 1984. Characteristics and tectonic significance of supra-subduction zone ophiolites. In Kokelaar, B. P., and Howells, M. F. (Eds.), Marginal basin geology. Spec. Publ. Geol. Soc., 16:77-96.

Price, I., 1976. Carbonate sedimentology in a pre-Upper Cretaceous continental margin sequence, Othris, Greece. Bull. Soc. Geol. Fr., 7: 273-279.

Rehault, J. P., Mascle, J., Fabbri, A., Moussat, E., and Thommeret, M., 1987. The Tyrrhenian Sea before Leg 107. In Kastens, K. A., Mascle, J., et al., Proc. ODP, Init. Repts., 107: College Station, TX (Ocean Drilling Program), 9-36.

Rio, D., Sprovieri, R., and Raffi, I., 1984. Calcareous plankton biostratigraphy and biochronology of the Pliocene-lower Pleistocene succession of the Capo Rosello area, Sicily. Mar. Micropaleontol., 9: 135-180.

Robertson, A.H.F., and Boyle, J. F., 1983. The origin and tectonic setting of metalliferous sediments in the Tethys Ocean. In Rona, P. A., Bostrom, D., Laubier, L., and Smith, K. L. (Eds.) Hydrothermal Processes at Seafloor Spreading Centers, New York (Plenum Press).

Robertson, A.H.F., and Dixon, J. E., (Eds.), 1984. The geological evolution of the eastern Mediterranean, Special Publ. Geol. Soc., 17, Oxford (Blackwell Scientific Publ.).

Robertson, A.H.F., and Woodcock, N. H., 1981. Gödene Zone, Antalya Complex, S.W. Turkey: volcanism and sedimentation of Mesozoic marginal oceanic crust. Geol. Rundschau, 70:1177-1214.

1982. Sedimentary history of the southwestern segment of the Mesozoic Tertiary Antalya continental margin. Eclogae Geol. Helv., 75:517-1214.

1984. The S.W. segment of the Antalya Complex, Turkey as a Mesozoic-Tertiary continental margin. In Robertson, A.H.F., and Dixon, J. E. (Eds.). The geological evolution of the Eastern Mediterranean. Spec. Publ. Geol. Soc. 17, Oxford (Blackwell Scientific Publ.), 251-272.

Ryan, W.B.F., Hsü, K. J., et al., 1973. Init. Repts. DSDP. 13, Washington (U.S. Govt. Printing Office).

Sartori, E., Mascle, G., Amaudric du Chaffaut, S., 1987a. A review of circum-Tyrrhenian regional geology. In Kastens, K. A., Mascle, J., et al., Proc. ODP, Init. Repts., 107: College Station, TX (Ocean Drilling Program), 37-64.

Sartori, R., et al. 1987b. Drillings of ODP Leg 107 in the Tyrrhenian Sea: tentative basin evolution compared to deformations in the surrounding chains-Mid-term conference "Lithosphere in Italy" ACC. NA2. LINCEI, Rome, 5-6 May 1987, pre-print, Vol. 0:125-138.

Scandone, P., 1979. Origin of the Tyrrhenian Sea and Calabrian Arc Bull. Soc. Geol. It., 98:27;-33.

Schreiber, B. C., 1982. Environments of subaqueous gypsum deposition. In Dean, W. E., and Schreiber, B. C. (Eds.) Marine Evaporites, Soc. Econ. Paleontol. Miner. Short course Notes, 4:43-73.

Searle, M. P., and Graham, G. M., 1982. "Oman Exotics"-oceanic carbonate build-ups associated with the early stages of continental rifting. Geology, 10:43-49.

Selli, R., 1974. Appunti sulla geologie del Mar Tirreno, Rend. Sem. Fac. Sci. Univ. Cagliari, 327-349.

Selli, R., and Fabbri, A., 1971. Tyrrhenian: a Pliocene deep sea. Rend. C. Fis. Mat. Acc. Nat., 50:104-116.
Sengör, A.M.C., and Yilmaz, Y., 1981. Tethyan evolution of Turkey: a plate tectonic approach. Tectonophysics, 75:181-241.

Shearman, D. J., 1966. Origin of evaporites by diagenesis. Trans. Inst. Min. Metall., 75:B208-215.

1982. Evaporites of coastal sabkhas. In Dean, W. E., and Schreiber, B. C. (Eds.), Marine Evaporites Soc. Econ. Paleontol. Miner. Short course Notes, 4:6-42.

Shipboard Scientific Party, 1987a. Site 651. In Kastens, K. A., Mascle, J., et al., Proc. ODP, Init. Repts., 107: College Station, TX (Ocean Drilling Program), 287-401.

1987b. Site 652. In Kastens, K. A., Mascle, J., et al., Proc. ODP, Init. Repts., 107: College Station, TX (Ocean Drilling Program), 403-597.

1987c. Site 653. In Kastens, K. A., Mascle, J., et al., Proc. ODP, Init. Repts., 107: College Station, TX (Ocean Drilling Program), 599-745.

, 1987d. Site 654. In Kastens, K. A., Mascle, J., et al., Proc. $O D P$, Init. Repts., 107: College Station, TX (Ocean Drilling Program), 747-875.

1987e. Site 655. In Kastens, K. A., Mascle, J., et al., Proc. ODP, Init. Repts., 107: College Station, TX (Ocean Drilling Program), 877-949.

1987f. Site 656. In Kastens, K. A., Mascle, J., et al., Proc. $O D P$, Init. Repts., 107: College Station, TX (Ocean Drilling Program), 951-999.

Simonian, K. A., and Gass, I. G., 1978. Arakapas Fault Belt Cyprus: a fossil transform fault. Geol. Soc. Am. Bull., 89:1220-1230.

Smith, A. G., 1971. Alpine deformation and the oceanic areas of Tethys, Mediterranean and Atlantic. Geol. Soc. Am. Bull., 82:20392070.

Stanley, D. J., and Wezel, F-C., 1985. (Eds.) Geological evolution of the Mediterranean basin, New York (Springer-Verlag), 1-589.

Steininger, F. F., and Rogl, F., 1984. Paleogeography and palinspastic reconstruction of the Neogene of the Mediterranean and Paratethys. In Robertson, A.H.F., and Dixon, J. E. (Eds.). The geological evolution of the Eastern Mediterranean. Spec. Publ. Geol. Soc. 17, Oxford (Blackwell Scientific Publ.), 659-668.

Thunell, R. C., 1979. Pliocene-Pleistocene paleotemperature and paleosalinity history of the Mediterranean Sea: Results from DSDP Sites 125 and 132. Mar. Micropaleontol., 4:173-187.

Treves, B., 1984. Orogenic belts as accretionary prisms; the example of the Northern Apennines, Ofioliti, 9:577-618.

Vail, P. R., et al., 1977. Seismic stratigraphy and global changes of sea level. In Payton, C. E. (Ed.). Stratigraphic interpretation of seismic data. Mem. AAPG, 26:49-212.

Villari, L., 1980. The Aeolian Islands. In Villari, L. (Ed.) An active volcanic arc in the Mediterranean Sea. Rend. Soc. It. Mineral. Petrol, $36: 369-414$

Von der Borch, C. C., 1976. Stratigraphy and formation of Holocene dolomitic carbonate deposits of the Coorong area, South Australia. J. Sediment. Petrol., 46:952-966.

Date of initial receipt: 25 September 1987

Date of acceptance: 13 February 1989

Ms 107B-179 


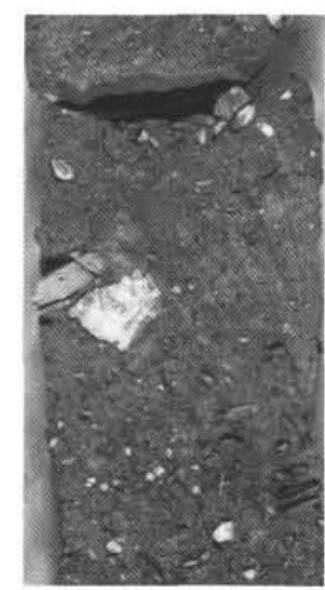

1

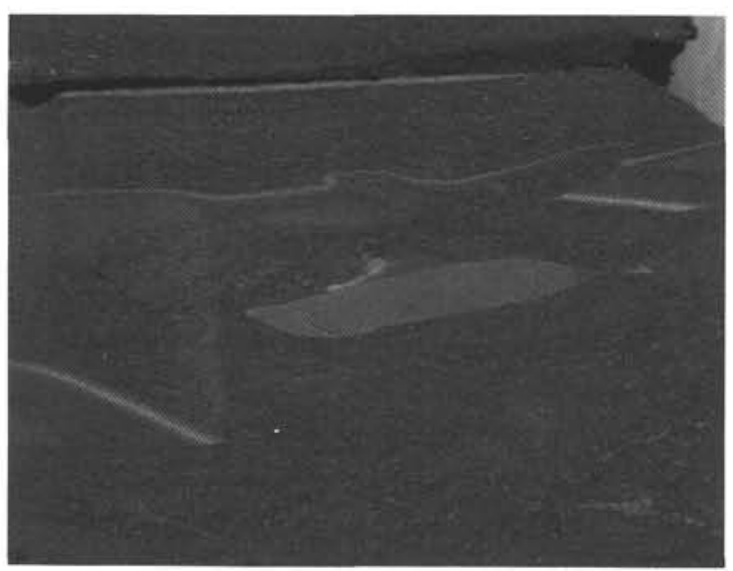

3

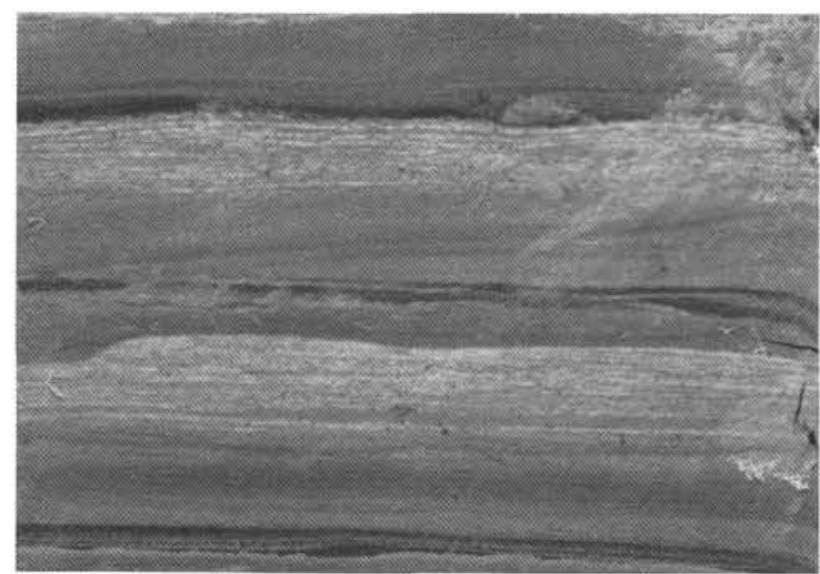

5

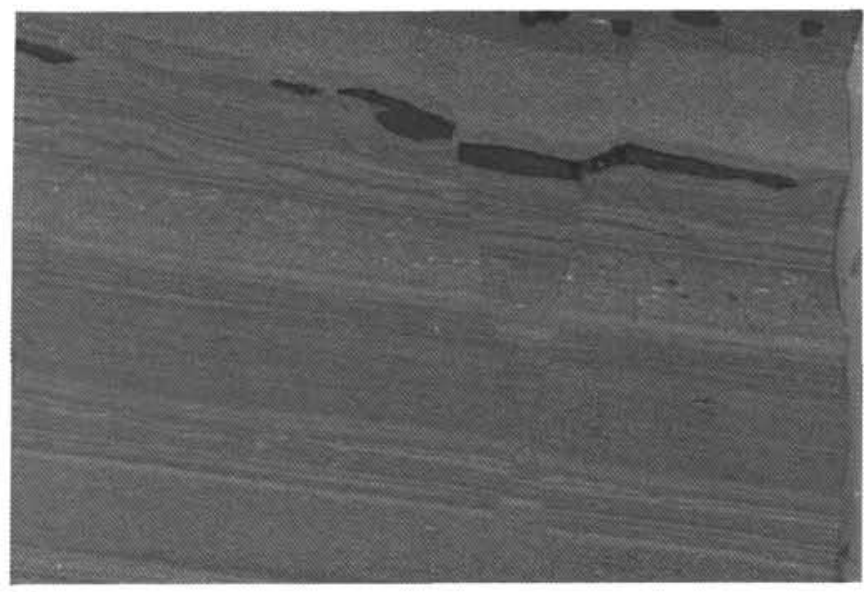

2
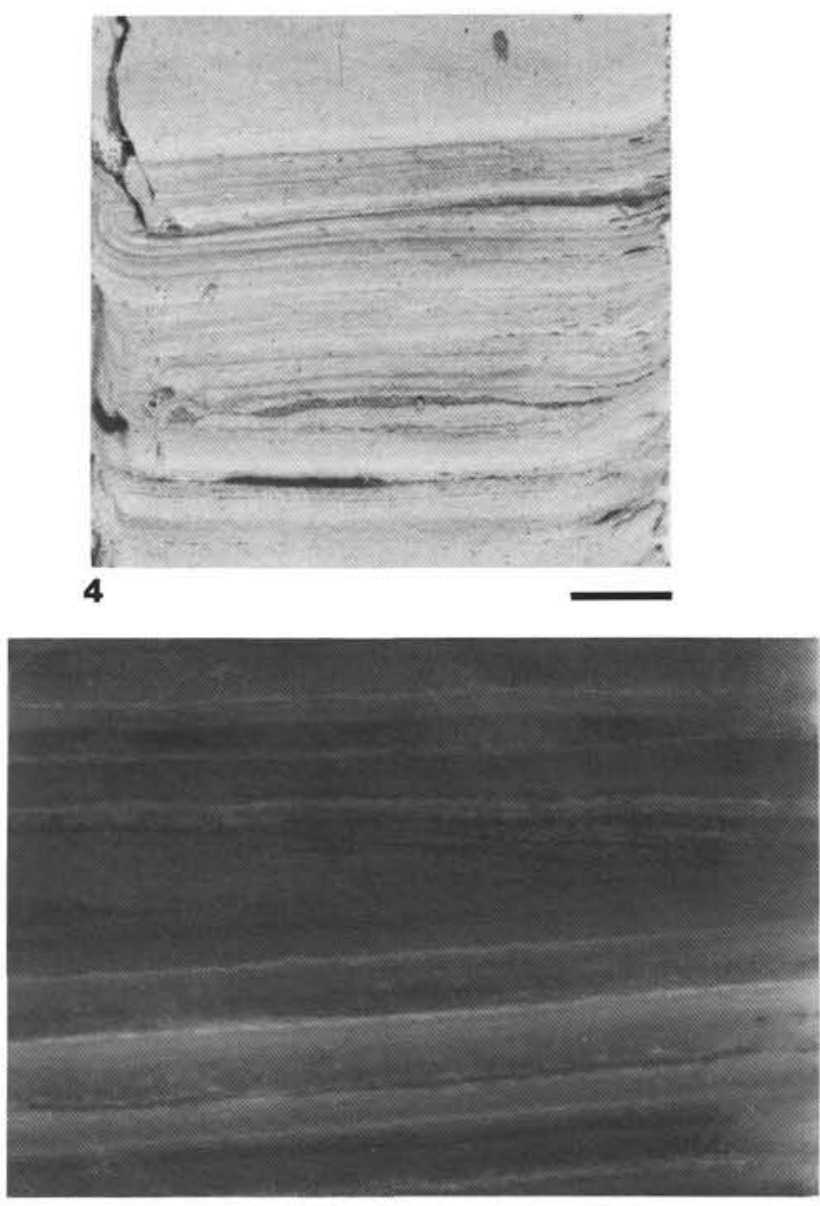

6

Plate 1. Core photographs. 1. Conglomerate composed of angular to subangular pebbles in a reddish mud matrix. Note matrix-supported texture; 107-654A-50R-1, 122-136 cm. 2. Finely-laminated pyritic claystone and dolomitic mudstone with minor tuff. Note the millimeter-thick lamination. The centimeter-thick slightly coarser layers were probably deposited from dilute turbidity currents, 107-654A-38R-1, 77-82 cm. 3. Finely-laminated organic-rich claystone that has been disrupted with the introduction of claystone intraclasts, 107-654A-39R-1, 74.5-78.8 cm. 4. Very finely-laminated gypsiferous and calcareous mud, typical of the horizons between the balatino-type gypsum in the basinal evaporitic succession, 107-654A-28R2, $0.5-7.0 \mathrm{~cm}$. 5. Repeated reverse-graded units. Greenish fine-grained gypsiferous mud with small Chondrites-type burrows, passes up into rippled gypsiferous and calcareous silt. Note the erosional truncation of the lowest reverse graded unit, suggestive of active bottom currents, 107-654A-30R-1, $35-40 \mathrm{~cm}$. 6. Finely-laminated balatino-type gypsum. Note the low-angle cross-lamination and the wavy lamination. The dark layers are pure gypsum, and pale layers more silty, 107-654A-32R-1, 43.5-46.5 cm. Scale bar $=1 \mathrm{~cm}$. 

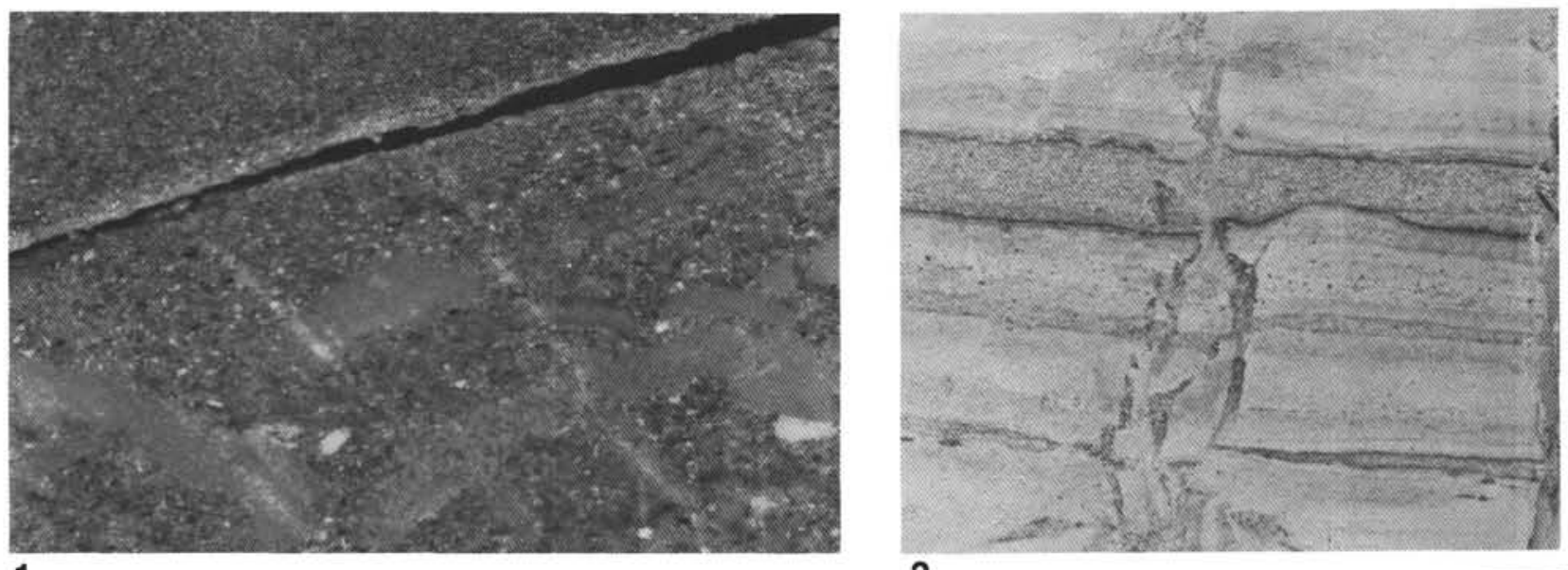

1

\section{2}

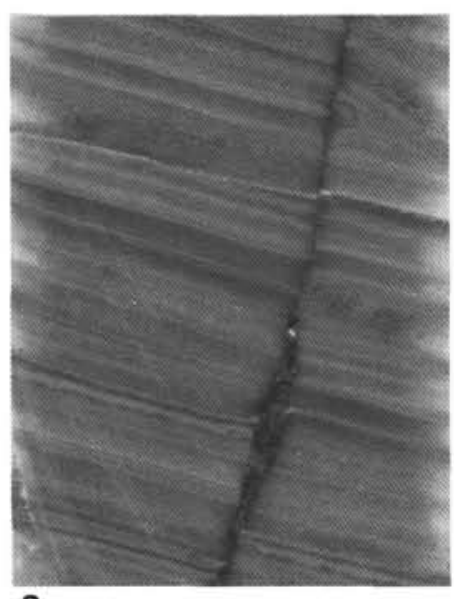

3
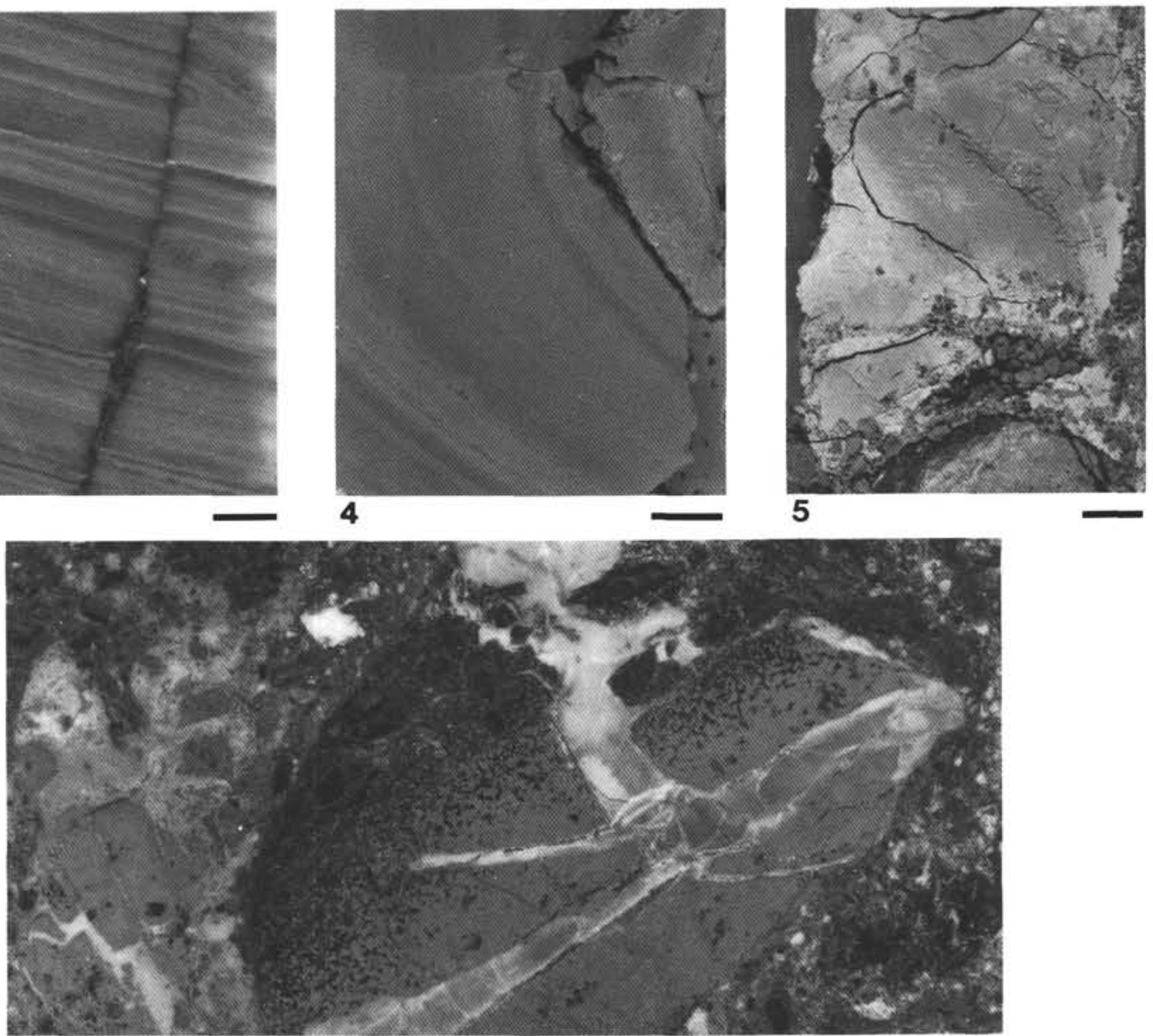

6

Plate 2. Core photographs. 1. Rare graded unit composed of medium- to coarse-grained sand with numerous rip-up clasts composed of finegrained gypsum. The bed is interpreted as a debris-flow passing into a turbidite. An intrabasinal origin is likely, 107-654A, 30R-1, 3.5-6.5 cm. 2 . Dewatering structure. The coarse-grained beds at the base appear to have dewatered forcing sediment of the same composition upward into the finegrained gypsiferous sediments above, 107-654A-29R-1, 134-140 cm. 3. Normal fault cutting balatino-type gypsum, 107-654A-30R-1, 108-116 cm. 4. Nearly vertically-inclined lamination within thinly bedded gypsiferous siltstone and mudstone. This is interpreted as part of a major syn-sedimentary slump unit, 107-652A-55R-4, 66-74 cm. 5. Depositional contact between chilled, altered basalt and pale green dolomite-rich compacted mud, that changes to yellow-green upward, 107-650A-66X-2, 53-63 cm. 6. Sedimentary breccia composed of basaltic fragments in a matrix of coarse-grained basalt-derived sediment. The large basalt clasts (bottom left) preserve an original chilled margin. Pore space is infilled with sparry calcite, 107-651A-53R-1, 144-148.5 cm. Scale bar $=1 \mathrm{~cm}$. 

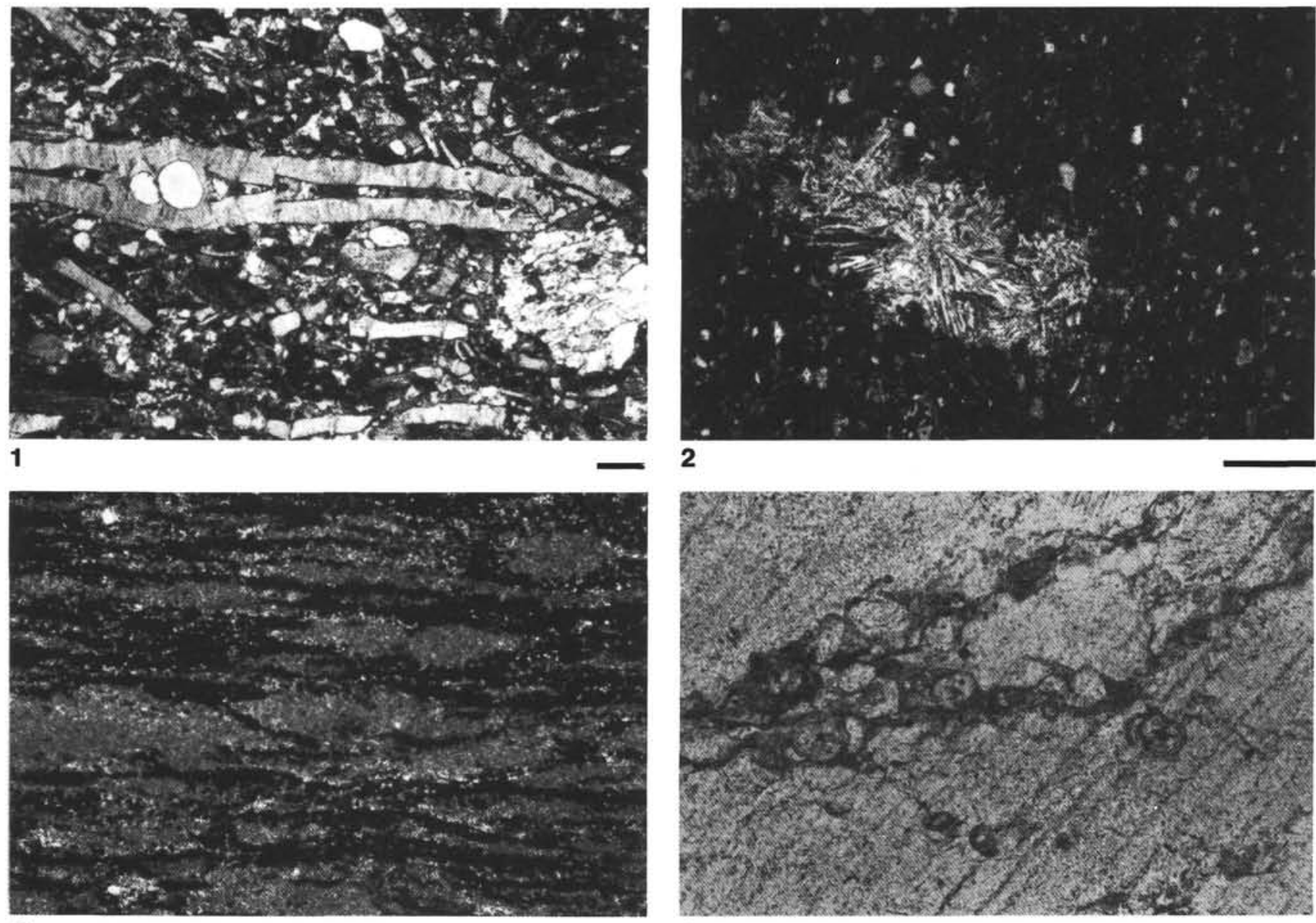

3

4
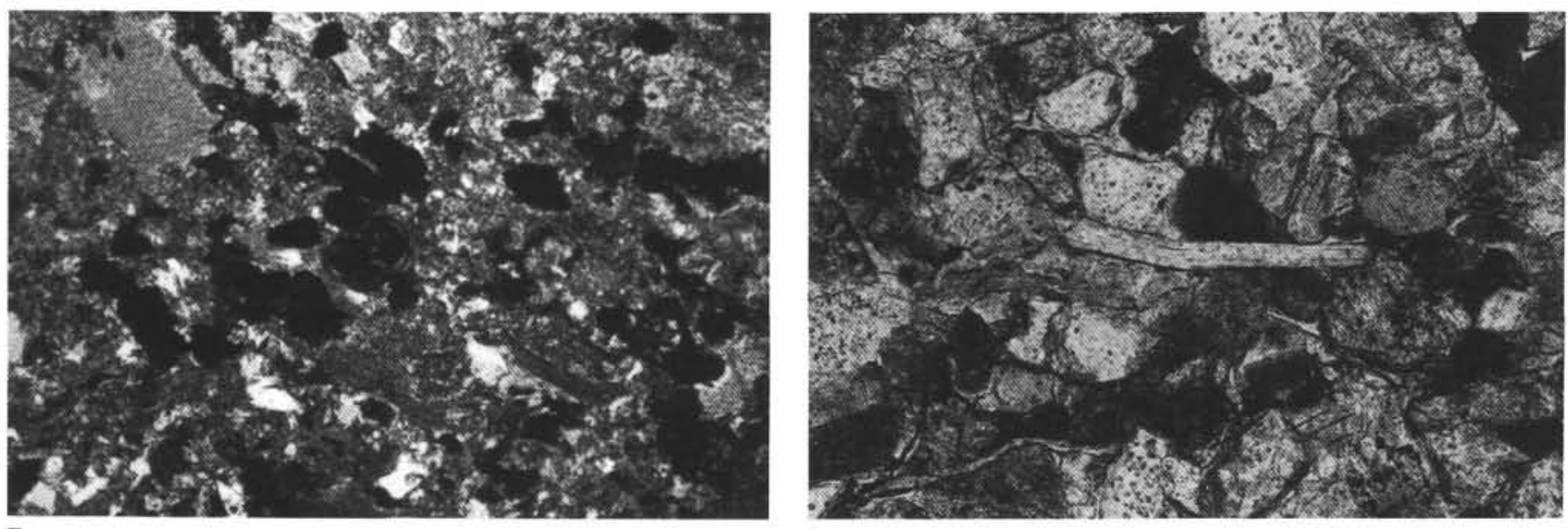

5

6

Plate 3. Photomicrographs. 1. Large forams, mostly fragmented in a matrix of medium- to coarse-grained sandstone. Much of the quartz is polycrystalline metamorphic in origin, 107-654A-46R-1, 50-53 cm. 2. Small anhydrite nodule in gypsiferous siltstone, 107-652A-46R-2, 127-129 cm. 3. Finely-laminated organic-rich mudstone. Contains fresh-water algae. See text for explanation. Note diagenetically formed lenticularity, 107-652A$64 \mathrm{R}-1,103-103 \mathrm{~cm}$. 4. Planktonic forams preserved in recrystallized gypsum, 107-654A-31-R-1, 117-119 cm. 5. Fine-grained sandstone composed mostly of detrital gypsum, quartz, and carbonate grains; includes planktonic forams, 107-654A-34R-4, $46 \mathrm{~cm}$. 6. Medium-grained sandstone composed of angular to subangular grains in a gypsiferous matrix, 107-652A-51R-5, 128-133 cm. Scale bar $=1 \mathrm{~mm}$. 

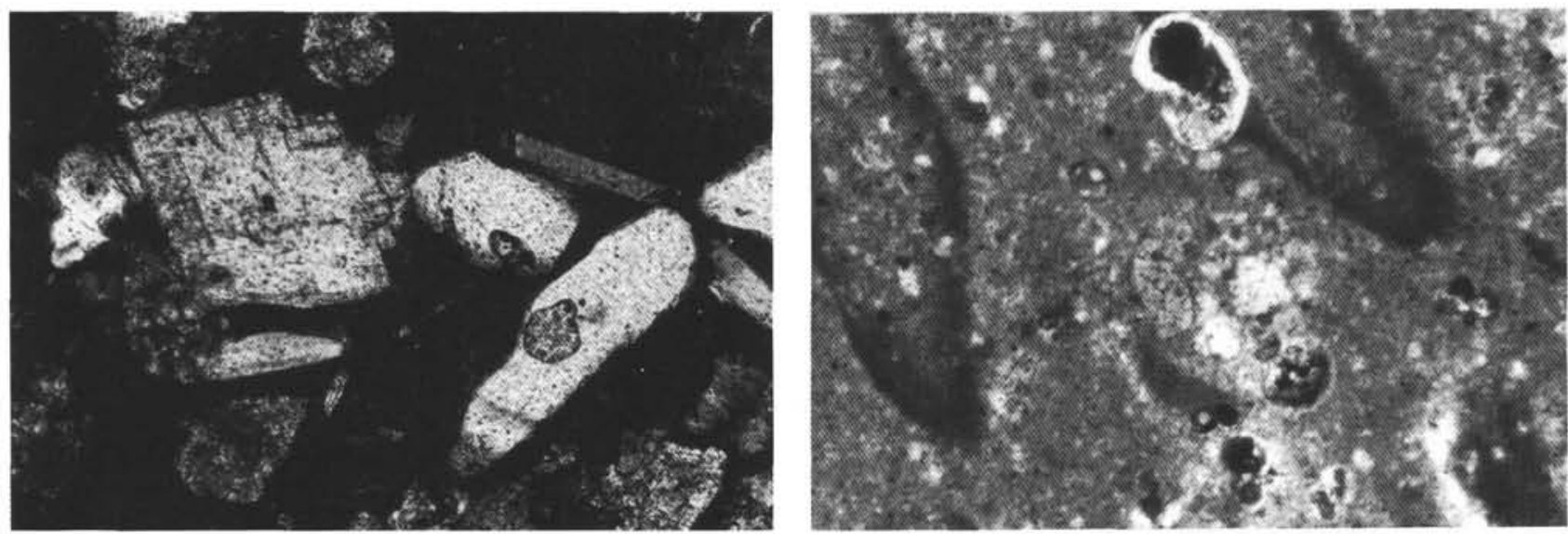

1
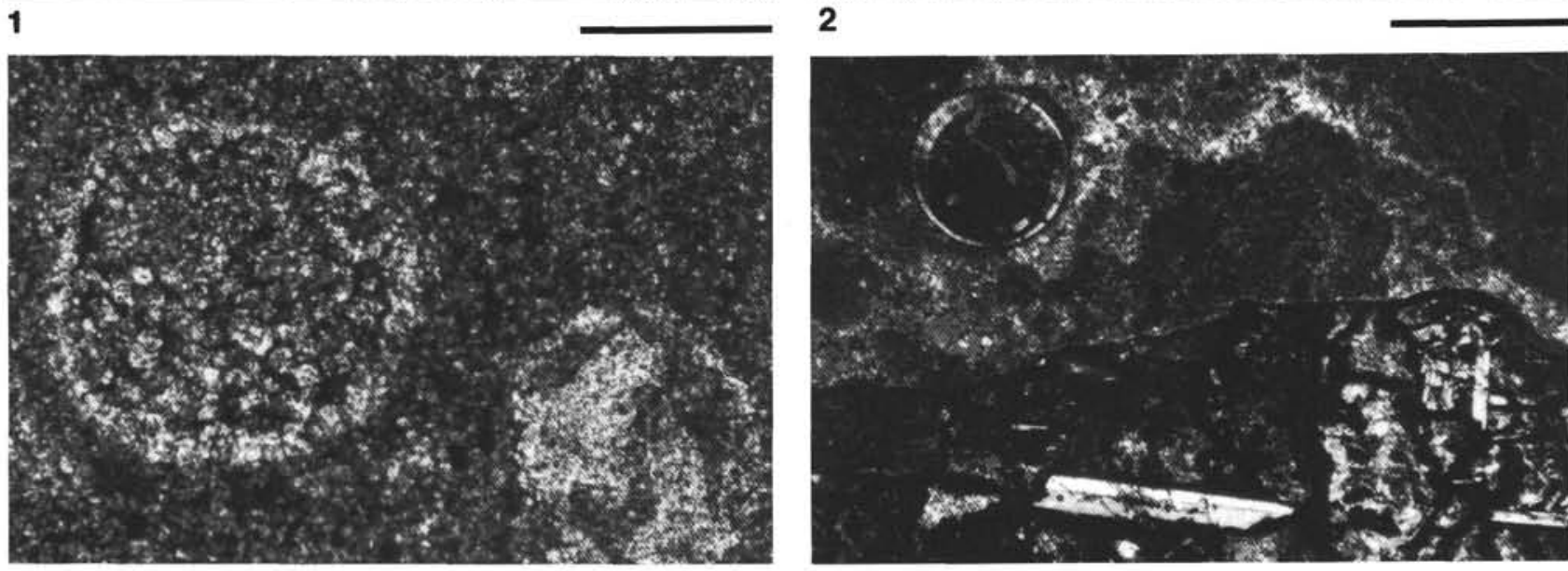

3

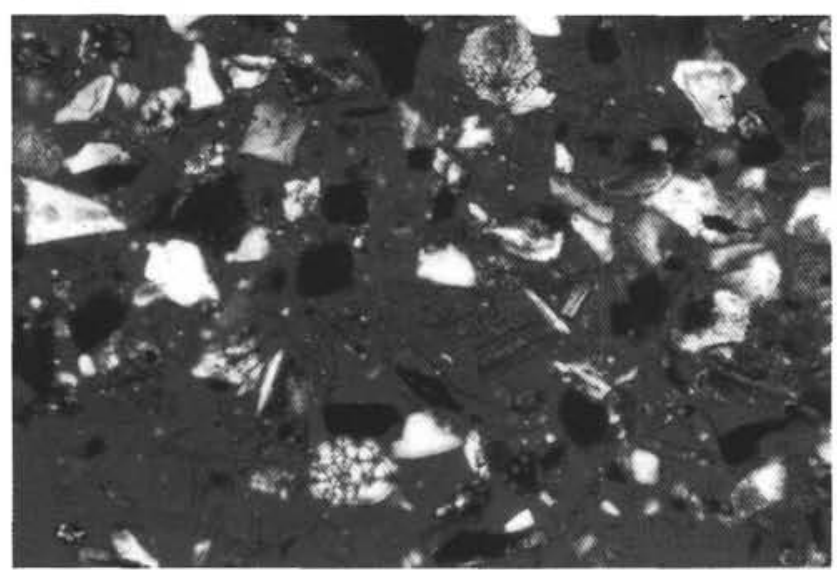

4

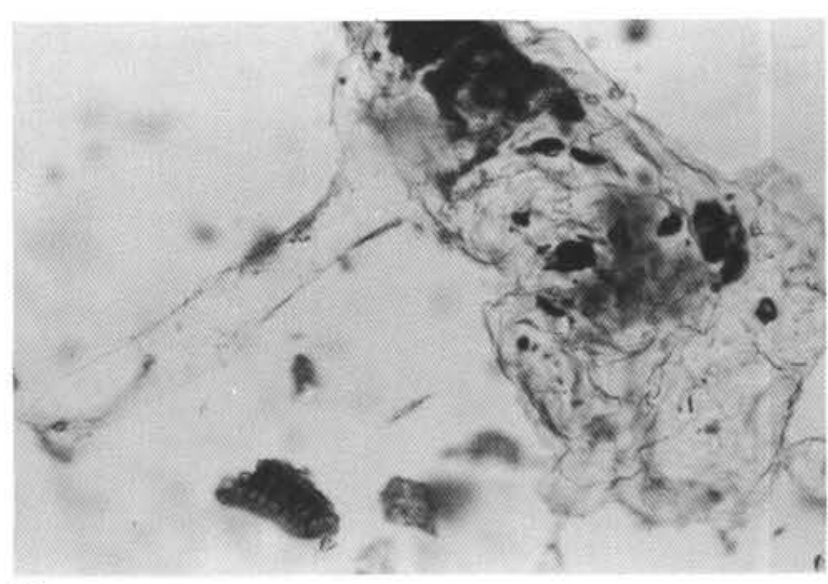

5

\section{6}

Plate 4. Photomicrographs. 1. Coarse-grained sandstone composed mostly of quartz, detrital gypsum, limestone, and reworked planktonic foram shells, 107-654A-46R-1, $50 \mathrm{~cm}$. 2. Planktonic foram in silty micrite within the igneous basement at Site 651 in the Vavilov Basin, 107-651A-53R-3, $40 \mathrm{~cm}$. 3. Pelagic micrite containing Pliocene planktonic foraminifera, interbedded with the igneous basement complex, 107-651A-52R-1, $110 \mathrm{~cm}$. 4. Partly recrystallized micrite in contact with unchilled basalt. Circular object is an artifact, 107-655A-10X, $76 \mathrm{~cm}$. 5. Volcaniclastic turbidite showing abundant fresh volcanic glass, quartz, and calcareous bioclastic grains, 107-650A-2-1, $58 \mathrm{~cm}$. 6. Very deformed spindle-like volcanic glass, $107-651 \mathrm{~A}-22 \mathrm{R}-1,24 \mathrm{~cm}$. Scale bar $=1 \mathrm{~mm}$. 


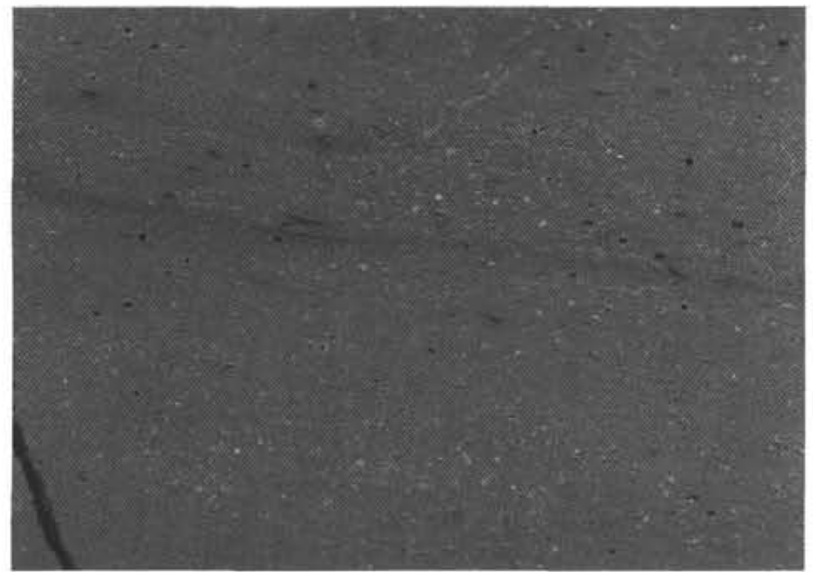

1

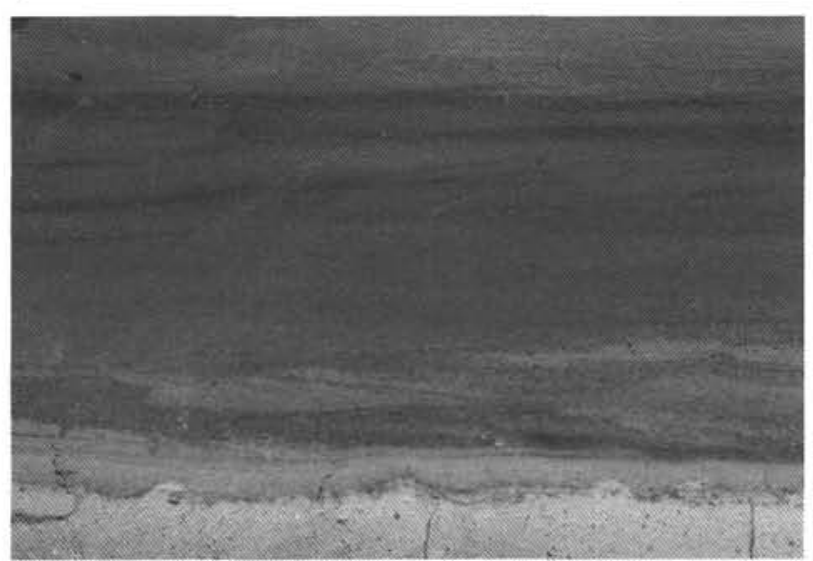

3

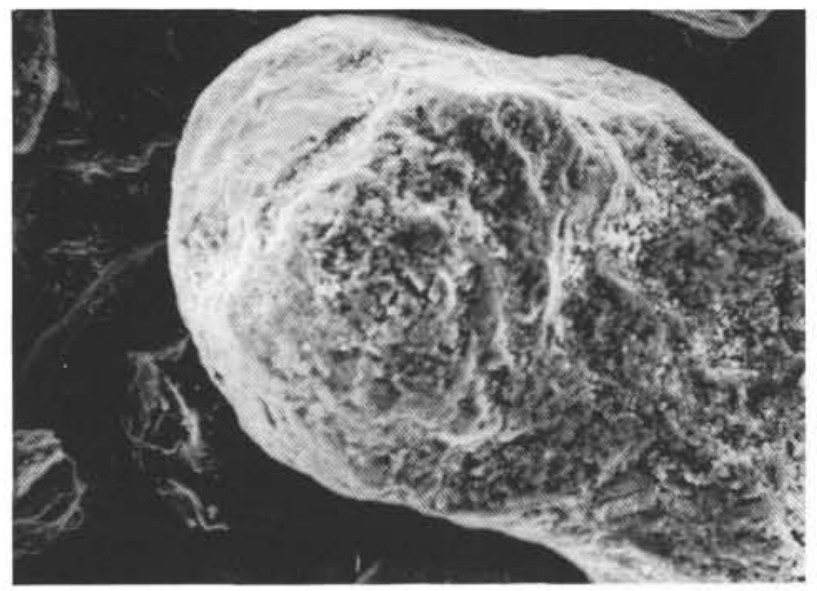

5

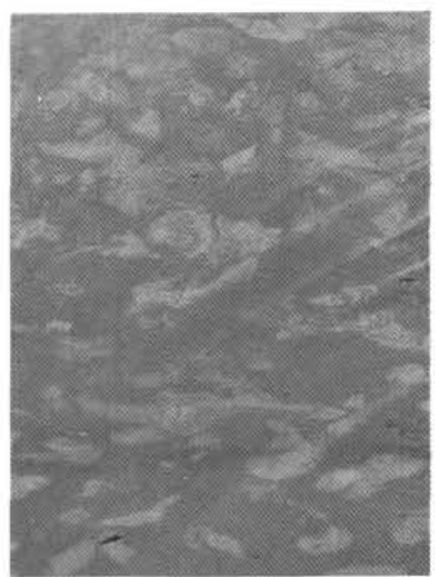

2

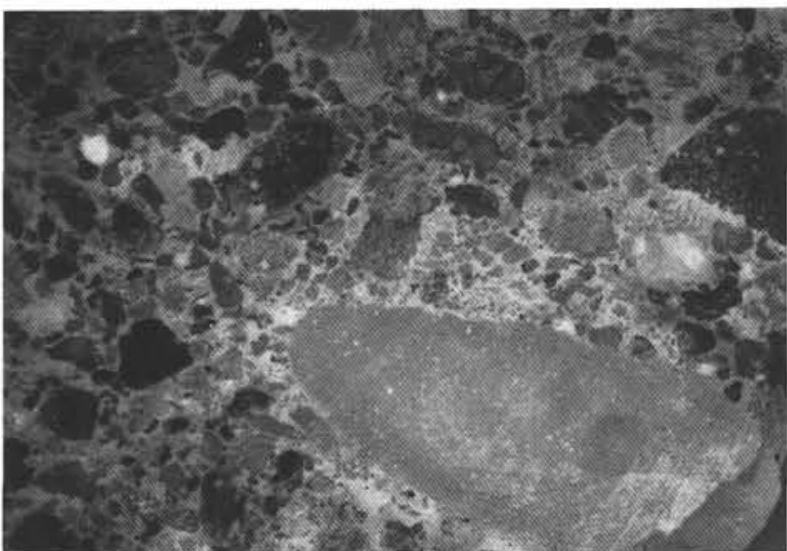

4

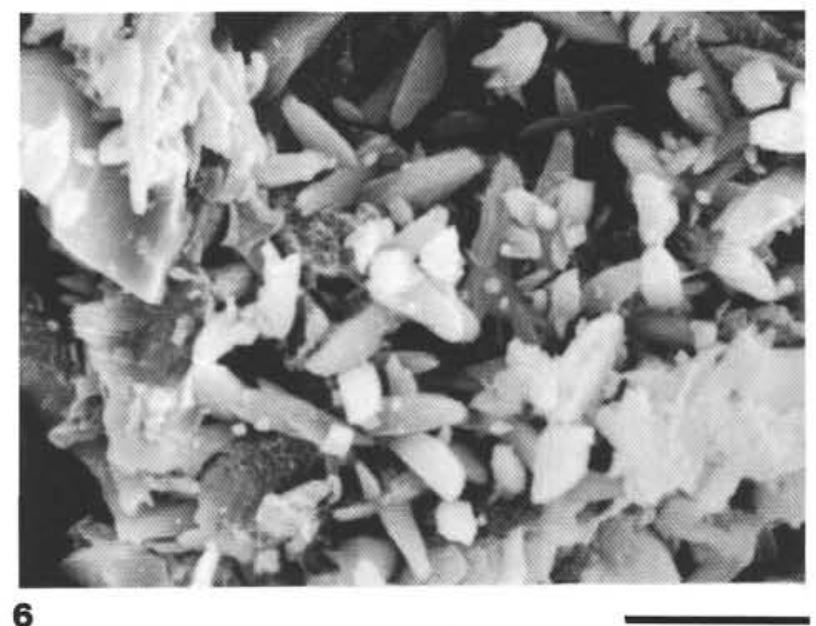

Plate 5. Core photographs and scanning electron micrographs. 1. Nannofossil ooze with scattered planktonic foram shells, 107-650A-64X-2, 114$118 \mathrm{~cm}$. 2. Muddy nannofossil ooze with tiny Chondrites-type burrows, $107-650 \mathrm{~A}-50 \mathrm{X}-6,106-110 \mathrm{~cm}$. 3. Volcaniclastic turbidite within nannofossil chalk. Mote the grading and small-scale ripple cross-lamination near the base of the turbidite, 107-651A-36R-4, 53-57 cm. 4. Volcaniclastic gravel cemented by white opaline silica believed derived from the local dissolution of volcanic glass, 107-651A-13R-6, 40-44 cm. 5. Scanning electron micrograph. Rounded quartz grain from $>63-\mu \mathrm{m}$ fraction of a volcaniclastic turbidite, Vavilov Basin, 107-650A-13X-CC. 6. Scanning electron micrograph. Volcanic glass almost entirely dissolved and replaced by zeolite and smectite, 107-650A-23X-CC. Scale bar $=1 \mathrm{~mm}$. 